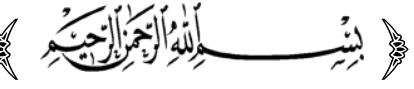

$$
\text { كلية التربية }
$$

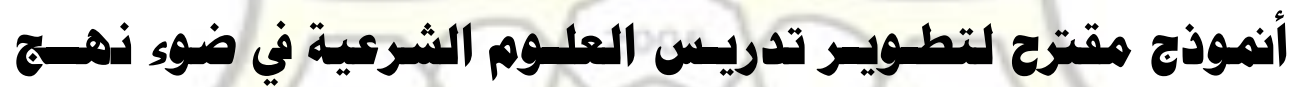

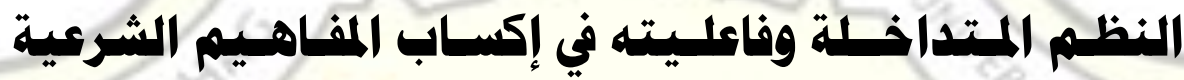

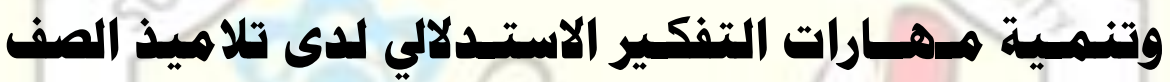
السادس الابتداشي في هدينة الرياض

$$
\text { إعداد }
$$

د. عوض بن صالح بن أحمد العمري د. ثابت بن سعيد آل كحلان القحطاني قسم الإثراف التريوي بإدارة التعليم قسم المناهج وطرق التدريس- كلية محافظة النماص التربية - جامعة الملك خالا المملكة العربية السعودية

\title{
DOI: 10.12816/EDUSOHAG.2020.79187
}

$$
\text { المجلة التربوية ـالعلد الثاذى والسبعوز ـ أبريل •r.rم }
$$

Print:(ISSN 1687-2649) Online:(ISSN 2536-9091) 


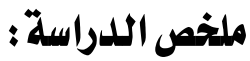

هافت الدراسة إلى تطوير تدريس العلوم الثرعية من خلال بناء أنموذجِ مقترحِ في ضوء نهج النظم المتداخلة؛ وتعرُّ فاعليته في إكساب المفاهيم الثرعية وتتمية مهارات التفكير

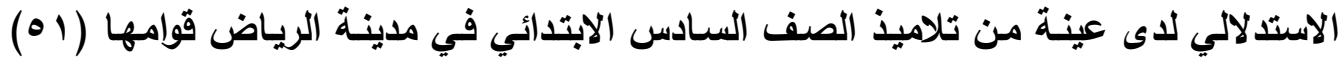

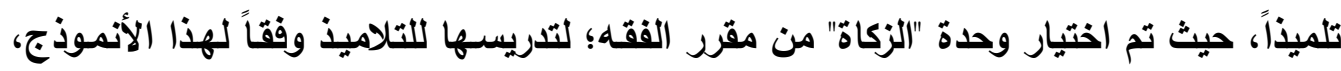

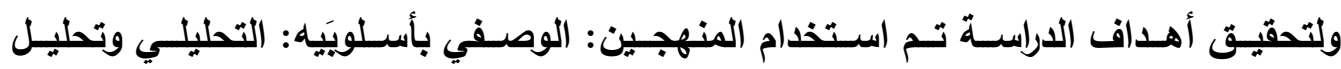

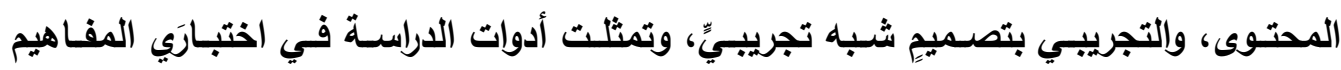

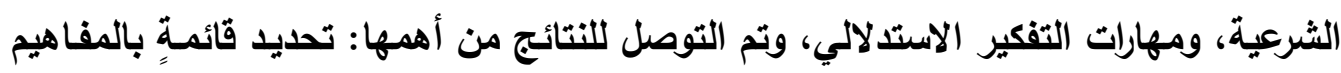

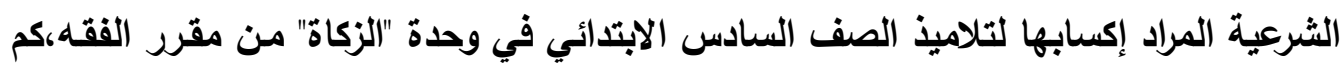

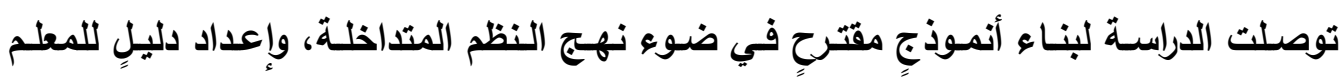

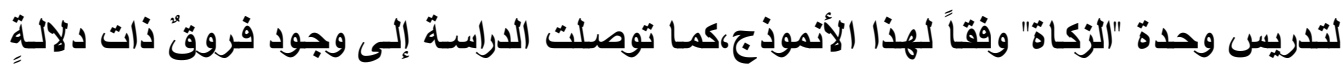

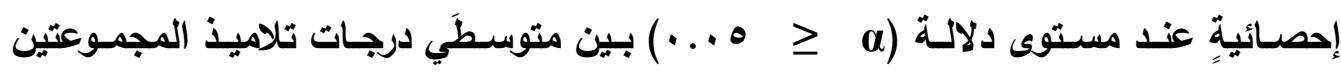

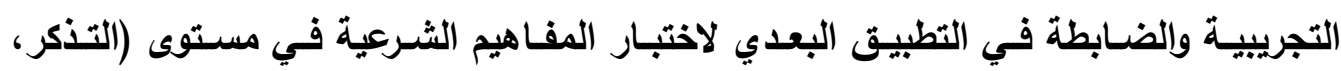

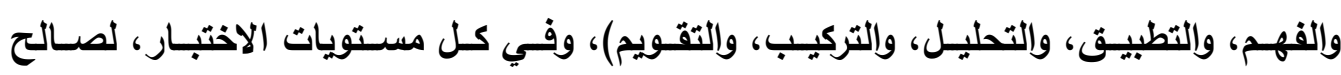

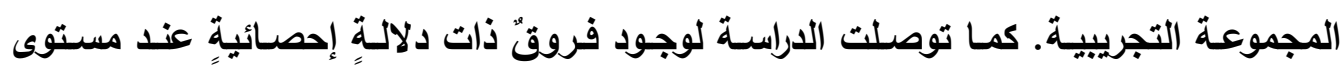

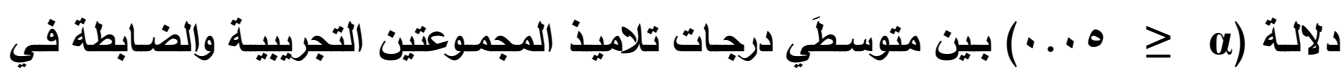

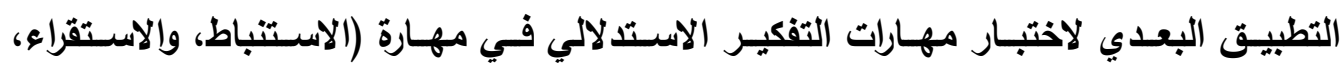

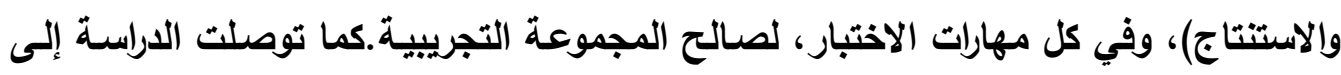

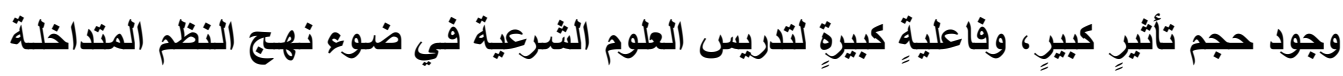

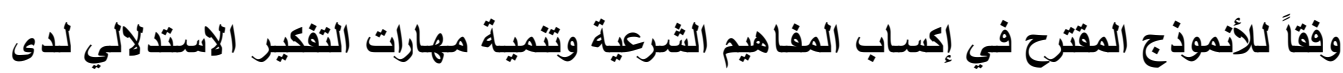
تلاميذ المجموعة التجريبية. وفي ضـوء هذه النتائج؛ أوصس الباحثّان بالإفادة مـن الأنموذج المقترح في تـريس

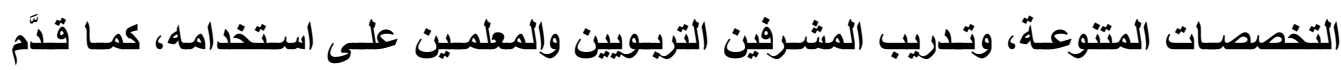
الباحثان عداد من البحوث والدراسات المقترحة. الكلمـات المفتاحيـة: تطوير التـريس- العلوم الثـرعية- نهـج النظم المتداخلـةالمفاهيم الثرعية- التفكير الاستدلالي. 


\section{Abstract}

This study aimed at developing the teaching of Sharia Sciences by building a suggested model in the light of the interdisciplinary approach and identifying its effectiveness in the acquisition of Sharia concepts and the development of deductive reasoning skills among a sample of (51) sixth-grade students in Riyadh. The unit on "Zakat" from the "Fiqh: Islamic jurisprudence" course was selected to be taught to the students based on this model. In order to achieve the objectives of the study, two descriptive methods were used, content analysis and a quasi-experimental design. The instruments of the study were the tests of Sharia concepts and the test of deductive reasoning skills. The study concluded with identifying a list of Sharia concepts to be taught to the sixthgrade students in the selected unit. The study also developed a suggested model in the light of the interdisciplinary approach and prepared a teacher's guide to teach the "Zakat" module according to this model. The results of the study showed statistically significant differences at the level of $(\alpha \leq 0$. 05) between the mean scores of the two experimental and control groups in the post-test of the Sharia concepts in levels of (remembering, understanding, application, analysis, synthesis and evaluation), and in all levels of the test, and in favor of the experimental group. The results also revealed the presence of statistically significant differences at the level of $(\alpha \leq 0$. 05) between the mean scores of the two experimental and control groups in the posttest of the deductive reasoning skills (deduction, extrapolation and inference), and in all skills of the test, and in favor of the experimental group. Finally, the results showed a presence of a large effect and great effectiveness for teaching of Sharia sciences in the light of the interdisciplinary approach in accordance to the suggested model in the acquisition of Sharia concepts and the development of reasoning skills among the students of the experimental group. In light of these results ، the study recommended the use of the suggested model in teaching of various disciplines and training of educational supervisors and teachers on its use. Moreover, the researchers presented several researches and suggested studies.

Keywords: Teaching development, sharia sciences, interdisciplinary approach, sharia concepts, deductive reasoning. 


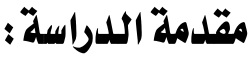

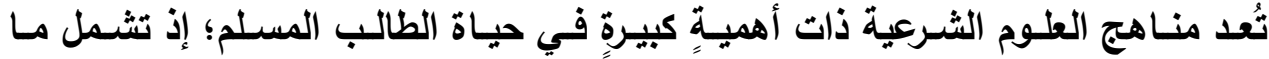
ينعكس إيجاباً على حياته في جوانب العقيدة والعبادات والمعاملات والقيم، وتكون دلالية خيرٍ لمن يتطمها ويدرك مفاهيمها؛ لقول النبي -صلى الله عليه وسلم- - "من يُرد الله بـه خيراً

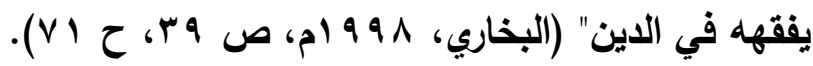
ونظراً لأهمية دراسة العلوم الثرعية؛ فإن وزارة التطليم في المملكة العربية السعودية قد

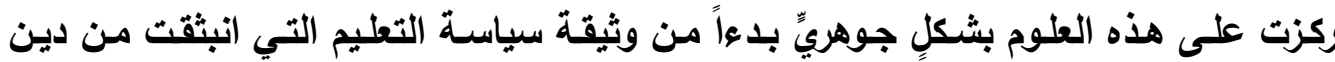

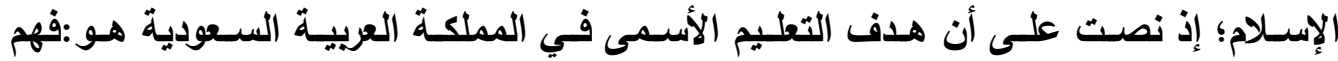

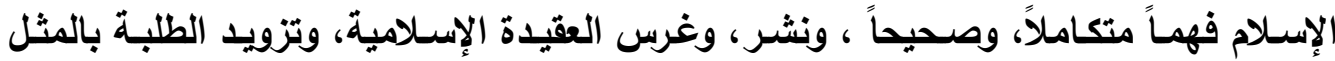
العليا، والقيم والتعاليم الإسلامية، وإكسابه المعارف والمهارات المختلفة، وتهيئة الفرد ليكون

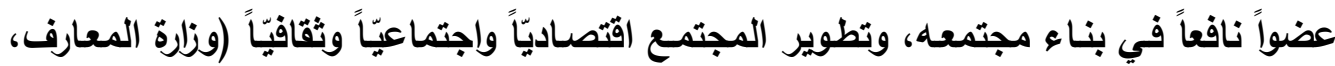
r Y Y ا هـ). كما نصَّ الأساس الحادي عشر من الأسس التي يقوم عليها التطليم في المملكة

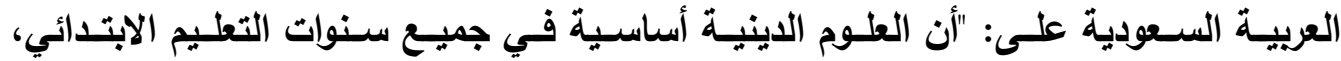

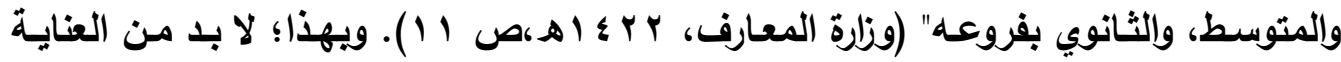
بتدريس العلوم الثرعية في جميع المراحل الدراسية بثكلٍ عامِّ، وفي المرحلة الابتدائية بثكلٍ

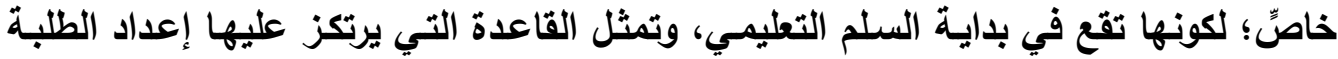

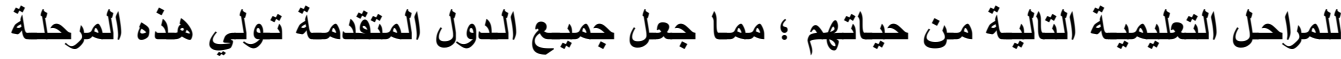

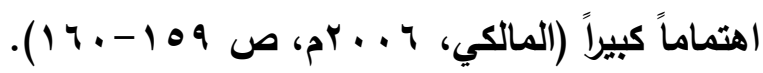

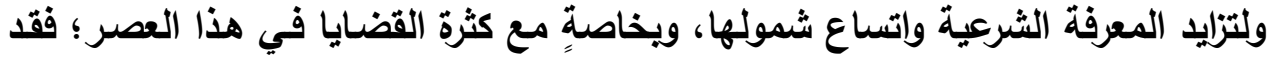

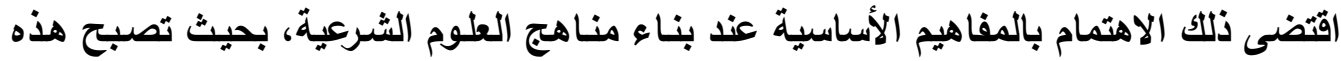
المفاهيم الأساس الذي يمكن أن يساعد في وضع الأهداف، وتنظيم المحتوى، واختيار وسائل

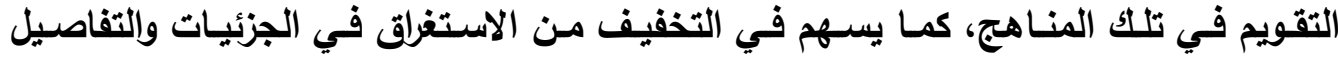

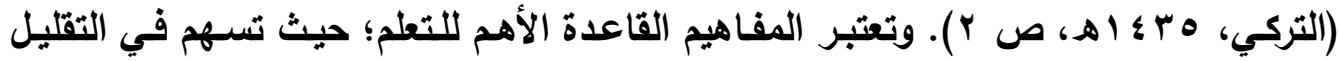

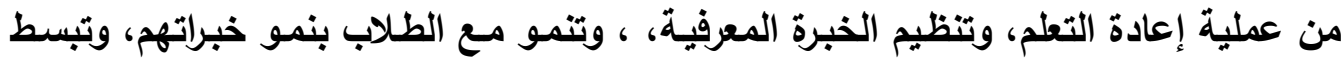

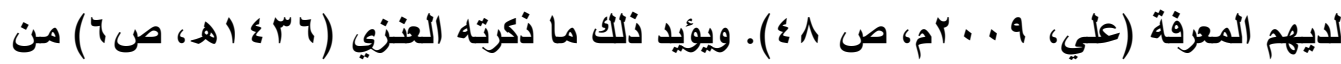

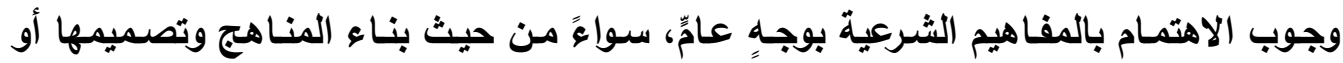


تدريسـها؛ وذلك لمـا يـتبط بها إصدار الأحكام، ومسن ثم السلوك الذي يتصـرفه الطلاب في حياتهم. ورغم هذه الأهمية الكبيرة للمفاهيم الشرعية؛ إلا أن نتائج بعض الدراسـات أكدت وجود مشكلاتٍ متعلقةٍ باكتساب الطلاب لهذه المفاهيم في مختلف المراحل الدراسية، ومنها دراسـة البلوي (V \& ا اهـ) التي أوضحت أن متوسط اكتساب طالبات الصف الثاني المتوسط للمفاهيم

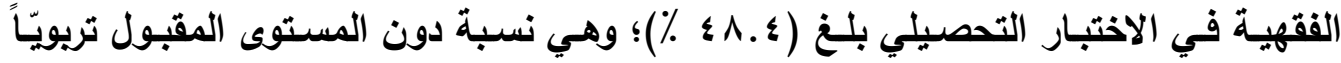

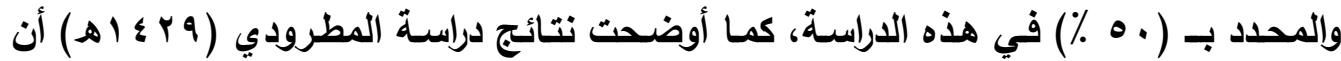
متوسط الإجابات الصحيحة في اختبار طلاب الصف السـادس الابتدائي للمفاهيم الفقهية بلغ

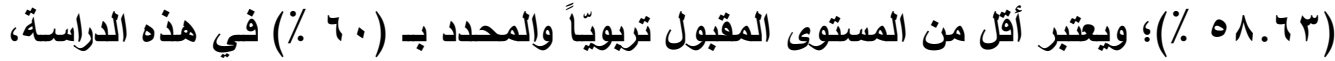

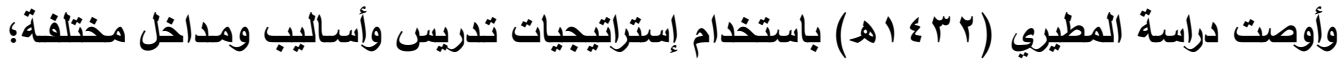
لتنمية المفاهيم الثرعية باعتبار هذه المفاهيم في المستوى الثاني من هرم البنية المعرفية، وذلك من اجل الوصول إلى المستويات الأعلى في الهرم.

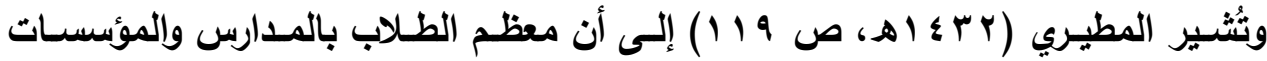
التعليمية يهتمون فقط بعملية حفظ المفاهيم والمعلومات، ويهملون استخدام عمليات التفكير، أي أن معظمهم يعانون من تدنٍّ في قدراتهم التفكيريـة. على الرغم من أن مهارات التفكير الاستـلالي قد حظيت بمكانـة متميزة ضمن مهارات التفكير التـي ينبغي أن توليها المنـاهج

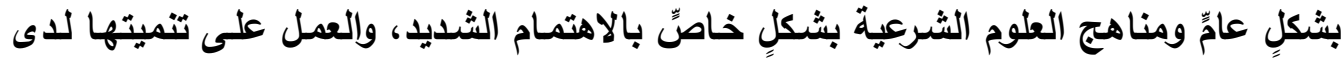
الطلاب؛ حتى يصبحوا قادرين على الملاحظة، والاستتباط، والاستقراء، واكتسـاب المفـاهيم، والنقد البناء للمعلومات، ولهذا؛ فعلى المعلمين مساعدة الطلاب في اكتسـاب مهارات التفكير

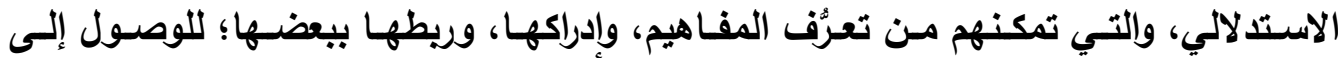

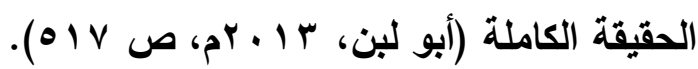

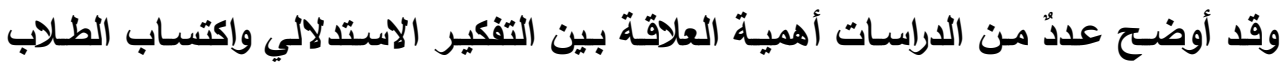

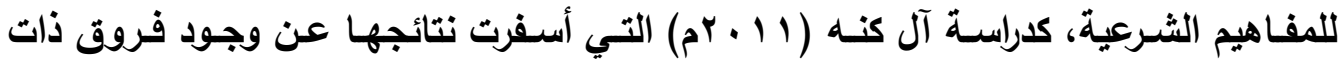
دلالة إحصائية عند مستوى دلالة ( الاستـلالي القبلي للدى أفراد المجموعة التجريبية من طلاب الصف السـادس في الثانويـات الإســلامية بـالعرلق، والتـي دُرسـت باسـتخدام طريقـة حلـ المشـكلات؛ بهـدف تنميـة التفكير 
الاستدلالي أثناء تــاول المفـاهيم الفقهيـة في مقرر الفقـه، ومتوسط درجـاتهم في الاختبـار البعدي، وذلك لصالح المجموعة التجريبية، وأوضحت دراسـة أبو لبن (r I ـ بم) أن التفكير الاستـلالي للدى طالبـات جامعة الأزهر يسـاعد في إطلاق حريـة التفكير أمسام الطالبـات في الاستدلال، والوصول إلى توظيف المعلومات المتاحة؛ لاكتساب المفاهيم الفقهية بشكلٍ أفضل.

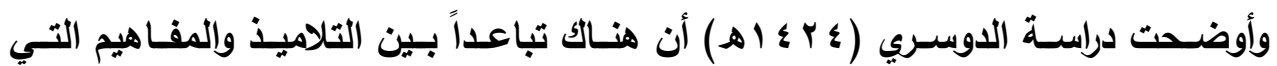
يدرسونها في مقررات العلوم الشرعية، وأن محتوالها لا يرتبط بحاجاتهم، وميولهه، واتجاهاتهم،

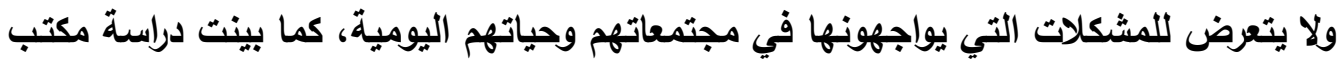

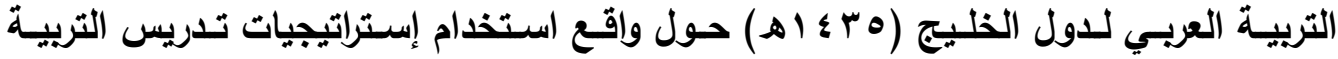
الإسـلامية مـن قبل المعلمين بمختلف المراحل الدراسية في الدول الأعضساء للدول الخليج العربي، وأن تعرُّف المعلمين للإستراتيجيات الحديثة وتطبيقهم لها كان بدرجةٍ متوسطةٍ.

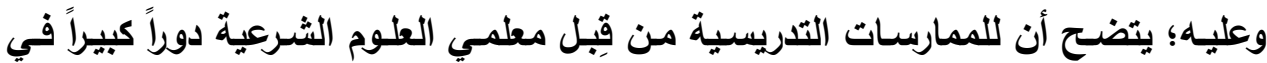
ضعف اكتساب الطلاب للمفاهيم الشرعية، وضعف مهارات التفكير الاستدلالي للايهم؛ ولذلك ينبغـي إعـادة النظـر فـي واقـع هـذه الممارسـات التـريسـية للمعلمـين، والاســفادة مسن الإستراتيجيات والأسـاليب والمداخل الديثة التي لاقت قبولاً واستحسـاناً في الميدان التربوي، ومنها استخدام نهج النظم المتذاخلة (Interdisciplinary Approach)؛ حيث يرى بوهم أن المعلمين نـادراً مـا يدرِّسون الموضسوعات بنهج النظم المتداخلة؛ (Boehm, 2003)

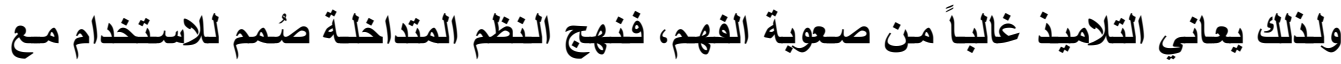
التلاميذ من سن الروضـة وحتى المراحل العليا، ويغطي التخصصـات العلميـة، والاجتماعية، والإنسانية بشكلٍ متسقِ، ويركز على العلاقات المتبادلة بين عوالم المعرفة. كما أن نهج النظم المتداخلة يستند إلى أسس النظرية البنائية، ويوازن بين أكثر من مقررٍ في عدة حقولٍ من المعـارف؛ فيتثـكل شــءٌ جليدٌ مـن الموضـوعات، ولا يمكن الفصل بينهـا، ويـريط المعـارف

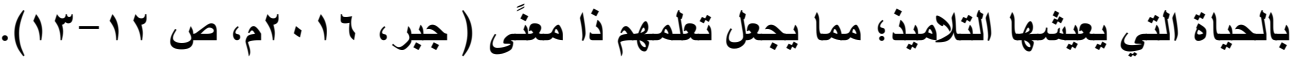
وقد تعدَّدت تعريفات نهج النظم المتداخلة في الأدب التريوي، ومنها تعريف دومان وأيبك, (Duman and Aybek 2003.p.6)

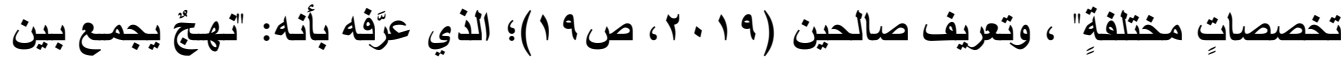

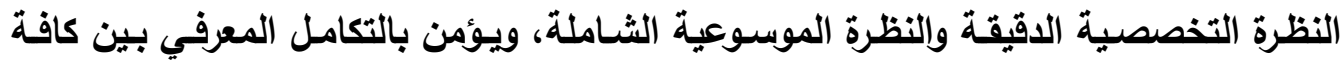




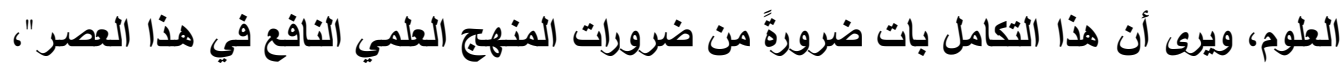

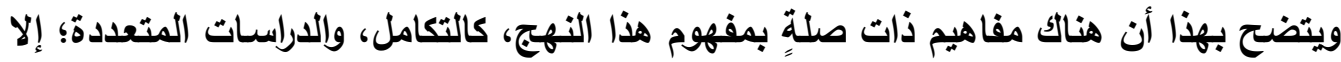

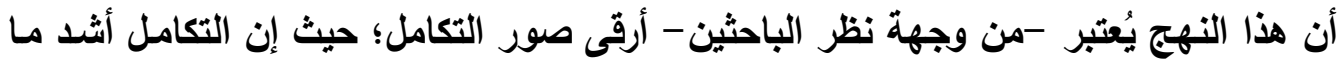

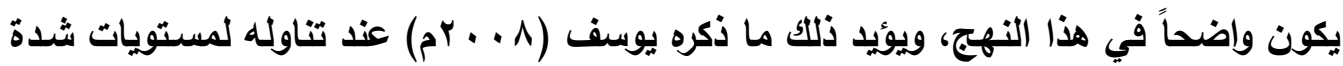
التكامـل حيث رأى أن أعلى هذه المستويات هـو التـداخل البينـي (Interdisciplinary) الاندماجي الذي يجمع بين الموضوعات أو المناهج في كلٍّ متداخلٍ متفاعلٍ يصعب معده إدراك الك

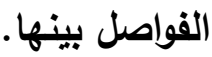
والمتأمل للمعارف في المجالات المتنوعة في هذا العصر يدرك تزايدها بشكلٍ سريعٍ؛

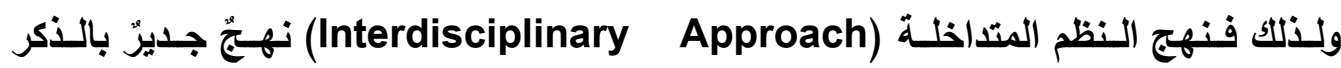

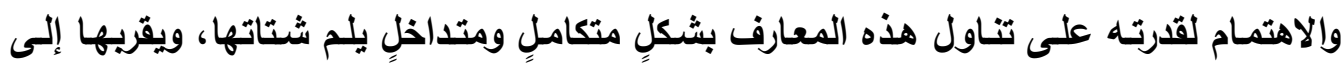

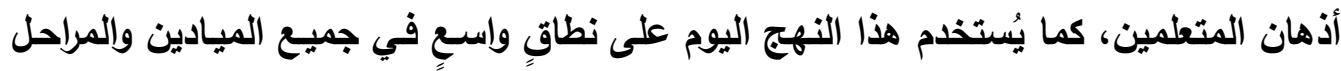

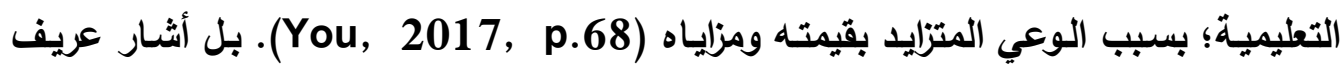
(r. lv)

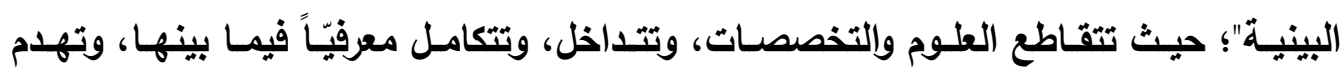

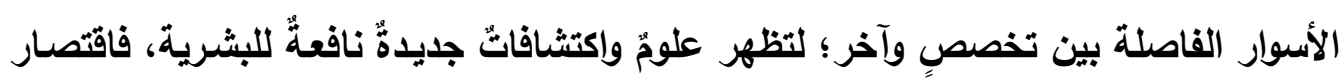

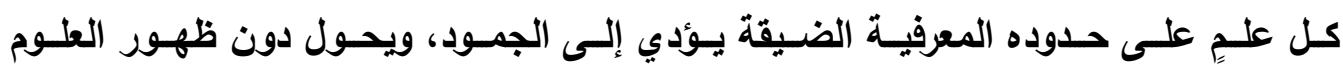

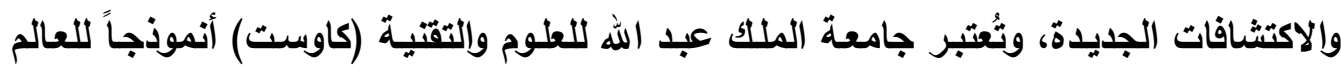

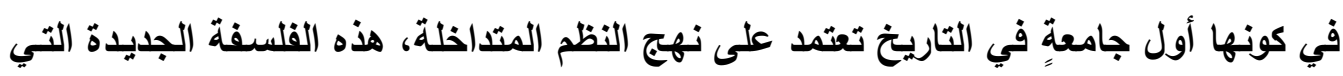

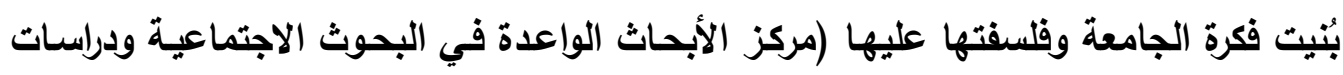

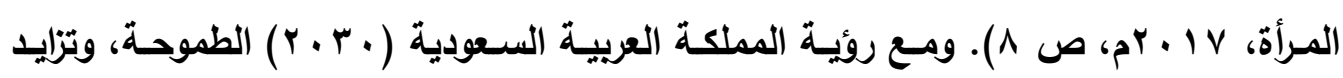

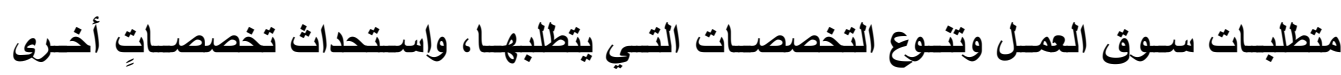

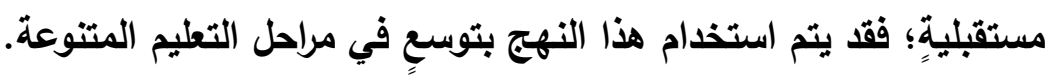

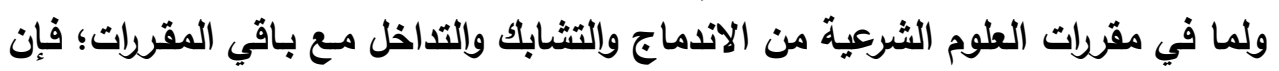
تدريسها في ضوء نهج النظم المتداخلة سينمي قدرة الطلاب على اكتساب المفاهيم الثرعية، كما سينمي مهارات التفكير الاستدلالي لليهم؛ لاكتساب هذه المفاهيم بصورةٍ أفضل. 


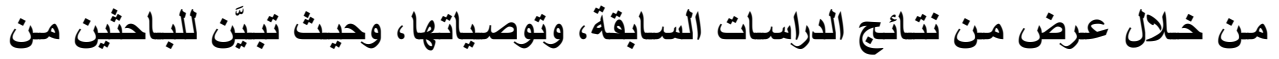

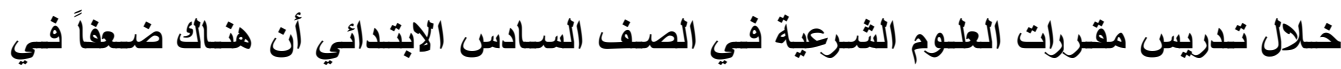

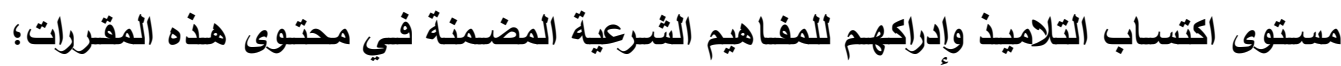
والذي قد يعود إلى ضعف مهارات التفكير الاستدلالي لديهم التي تساعدهم في اكتساب تلك

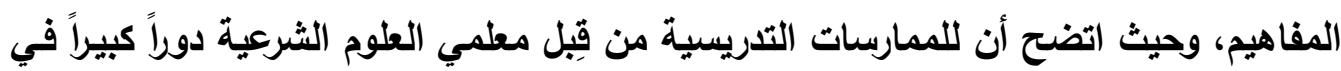
هذا الضعف؛ فينبغي إعادة النظر في واقع هذه الممارسات، ومن ثم تطويره.

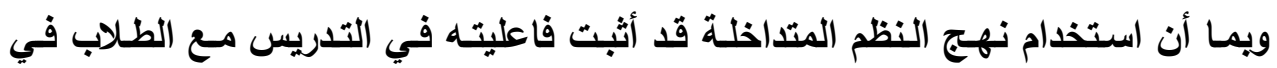

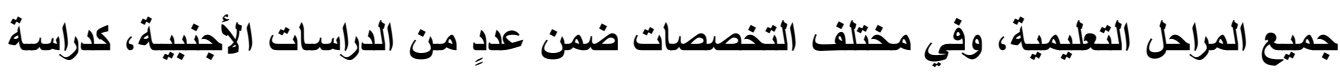
ديميرل وكوسكن (Demirel and Coskun, 2010) التي هدفت إلى تعرُّن أهمية تطبيق نهج النظم المتداخلة المستتل إلى التطلم القائم على المشروعات في مدارس مدينة

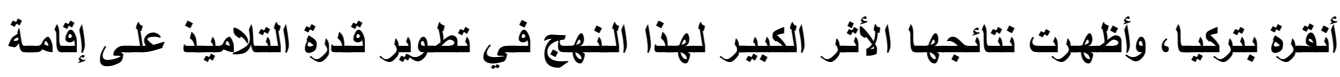

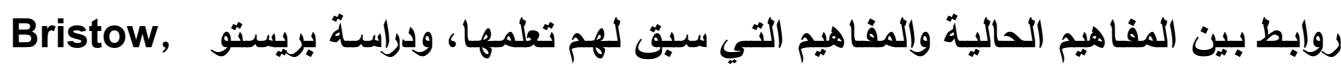

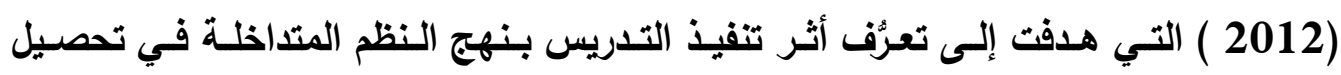

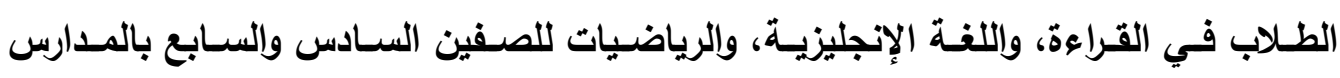

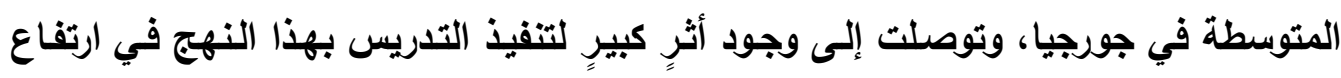

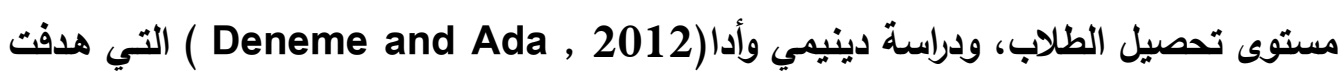

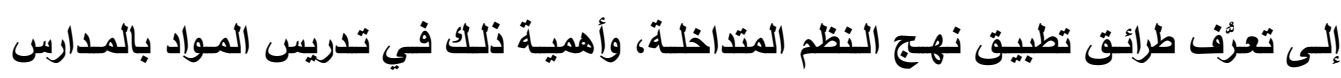
الابتدائية في تركيا، وتوصلت إلى أن استذام هذا النهج في التدريس أدى إلى زيادة فهر

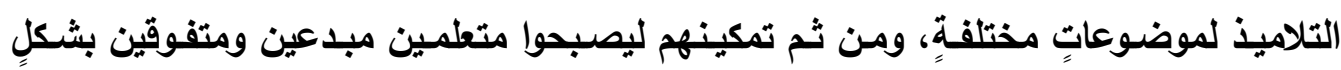

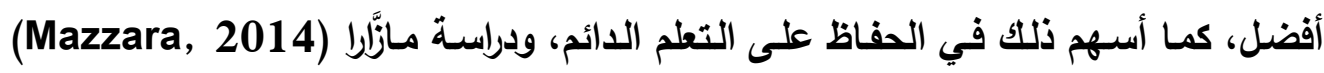

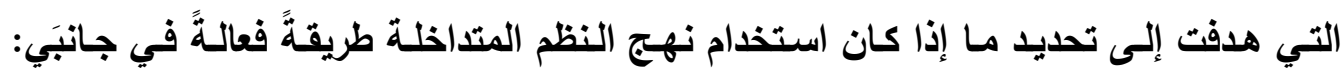
تدريس المعرفة الرقمية ضمن مهارات القرن الحادي والعشرين، وكيفية الاستعداد الوظيفي

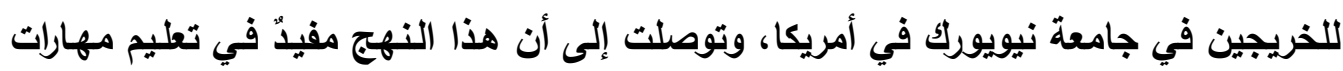

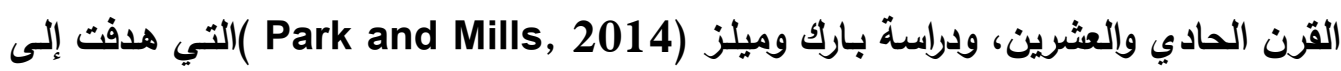
تعرُفت تصورات طلاب السنة الأولى المسجلين في دورةٍ تستخدم نهج النظم المتداخلة في 
تـدريس تقتيـة المعلومـات والتصـيم المرئسي مـن خـلال المـودل ممـثلاً في نظـام إدارة التعلم

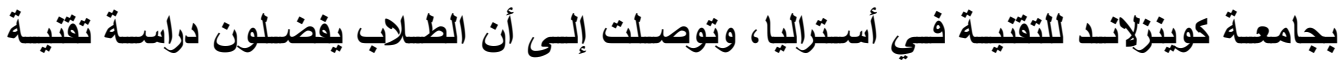
Sagdic and المعلومات والتصميم المرئي باستخدام هذا النهج، ودراسة ساجديك وديميركايا (التي هدفت إلى تقويم نهج النظم المتداخلة في تدريس الجغرافيا (Demirkaya, 2014)

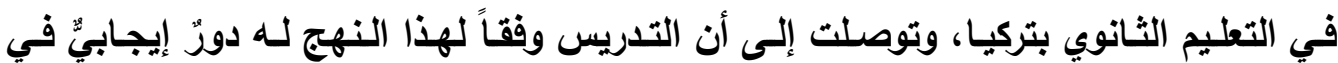
ترسيخ مفـاهيم الموضـوع الدراسـي، وزيـادة دافعيـة الطـلاب نحس التعلم، وممارسـة التفكير، والقدرة على الاستتتاج بسـهولةٍ، ودراسـة يو (You, 2017) التي هدفت إلى وصف تاريخ التدريس بنهج النظم المتداخلة، واتجاهاته، وتوضيح الأطر المفاهيمية وأهمية التدريس وفق فئق

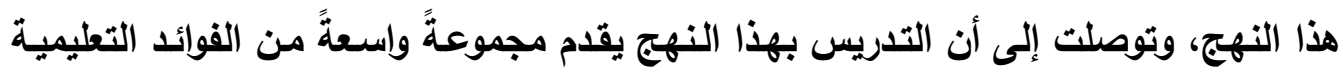

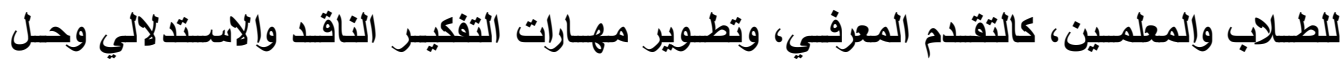
المشكلات، وتطوير جوهر المعرفة العام، وتعميق فهمها، ومن ثم تحسين مستوى تحصيل الطلاب، ومساعدتهم على فهم القضايا والمشكلات التي يتم تقديمها في سياقاتِ واقعيةٍة من الناحيـة العلميـة، والتعامـل معهـا باسـتخدام المعـارف والمهـارات ذات الصـلة بتلـك القضــايا

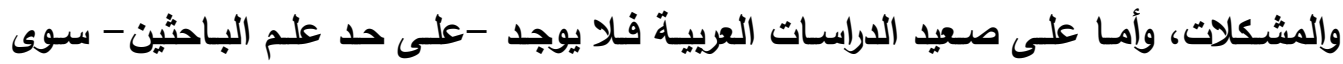
دراسة جبر (1 1 • rم) التي أوصت فيها بتنفيذ أبحاثٍ علميةٍ حول هذا النهج بشكلٍ خاصِّ؛

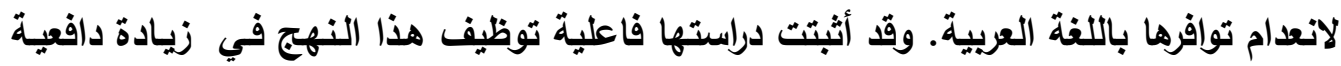
التلاميذعلى التفكير الإبداعي محافظة سلفيت بفلسطين.

وممـا سيقِ؛ فإن مشكنة الدراسـة تتلخص في ضعف اكتسـاب تلاميذ الصف السـادس الابتــائي للمفـاهيم الثـرعية في مقـررات العــوم الشـرعية، وكــلك تـدني مهـارات التفكير الاستدلالي لايهم؛ حيث اتضح أن للممارسات التدريسية من قِبل معلمي العلوم الشرعية دوراً

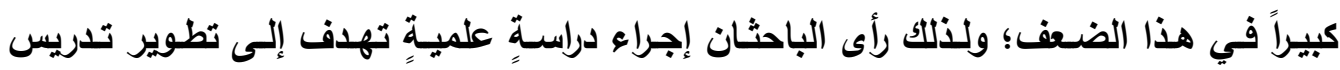
العلوم الشرعية في ضوء أحد مداخل التدريس العالمية الحديثة، وهو نهج النظم المتداخلة. 


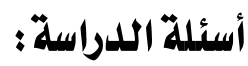

\section{سعت هذه الاراسة للإجابة عن الأسئلة الآتية:}

1) ما المفاهيم الثرعية المراد إكسابها في العلوم الثرعية لتلاميذ الصف السادس الابتدائي؟

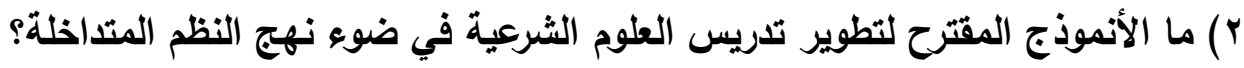

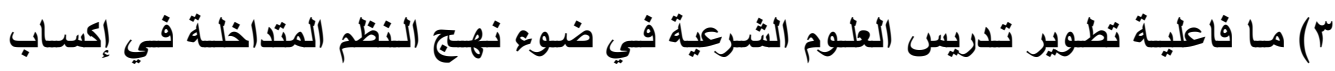
المفاهيم الثرعية لتلاميذ الصف السادس الابتدائي في مدينة الرياض؟ ؛) ما فاعلية تطوير تدريس العلوم الثرعية في ضوء نهج النظم المتداخلة في تنمية مهارات

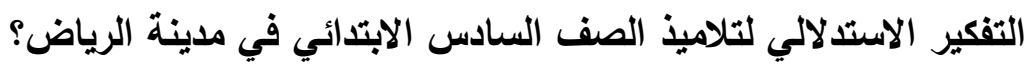

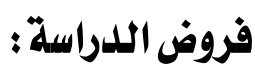

تحدَّدت فروض الدراسة في الفرضين الآتيين:

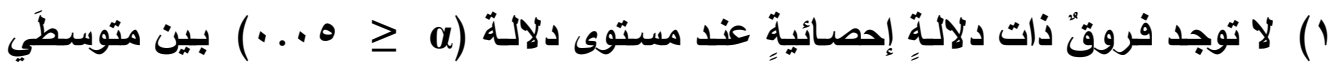
درجات تلاميذ المجموعتين التجريبية والضـابطة في التطبيق البعدي لاختبار المفاهيم

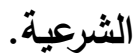

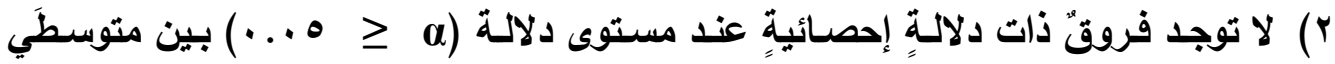

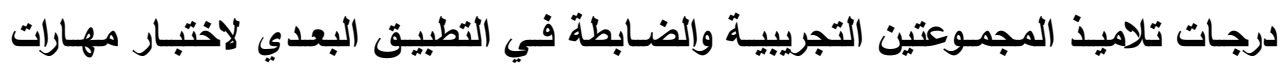

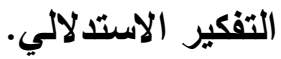

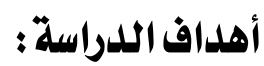

سعت هذه الاراسة إلى تحقيق الأهداف الآتية:

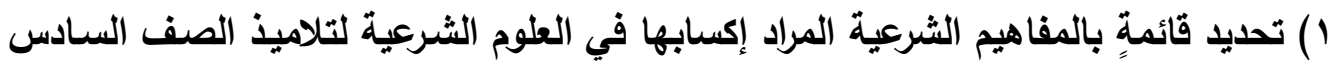
الابتدائي. r) بناء أنموذجٍ مقترحِ في ضوء نهج النظم المتداخلة؛ ليسهم في تطوير واقع تدريس العلوم الثرعية. r) تعرُّف فاعلية تطوير تدريس العلوم الثرعية في ضوء نهج النظم المتداخلة في إكساب

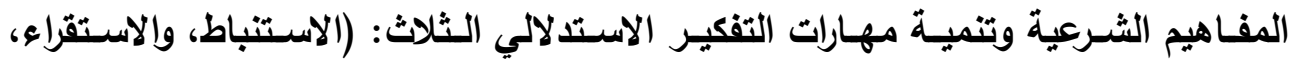
والاستنتاج) لاى تلاميذ الصف السادس الابتدائي في مدينة الرياض. 


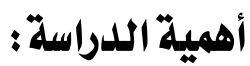

يمكن إبراز أهمية هذه الاراسة على النحو الآتي:

( ) الاستجابة للاتجاهات التريوية الحايثة التي تنادي بأهمية تعليم المفاهيم؛ لكونها تثكل التهل

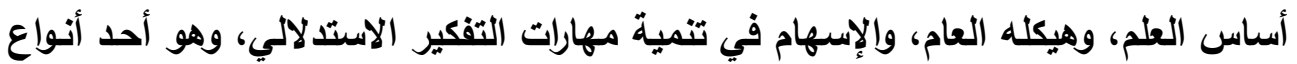

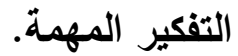

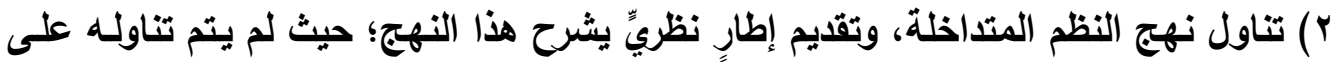

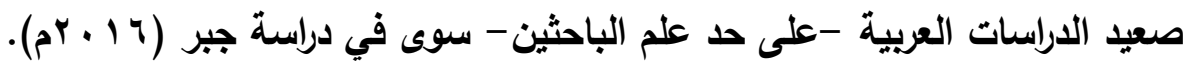

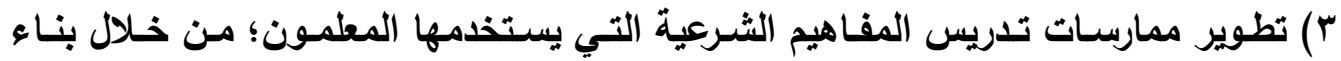

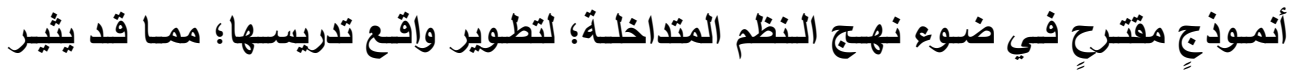
الهتمامهم لمراجعة الممارسات الحالية في التدريس.

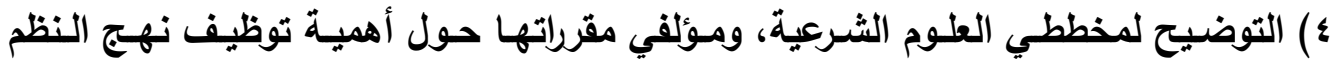
المتداخلة في إكساب المفاهيم الثرعية وتنمية مهارات التفكير الاستدلالي لاى التلاميذ.

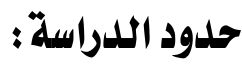
تم تطبيق هذه الدراسـة على المدارس الابتدائية للبنين بمدينة الرياض، خلال الفصل

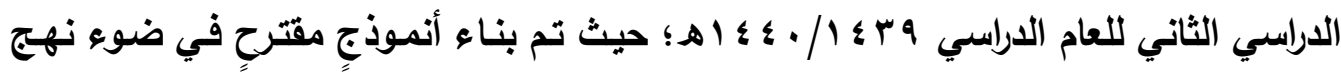
النظم المتداخلة؛ لتطوير تدريس وحدة "الزكاة" من مقرر الفقه ضمن مقررات العلوم الثرعية بالصف السادس الابتدائي؛ وسبب اختيار هذه الوحدة يعود لاطلاع الباحثين على محتوى

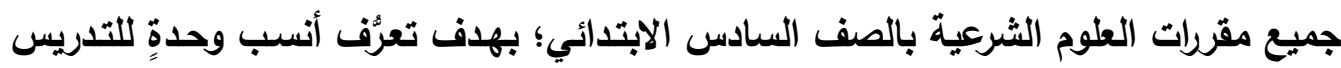

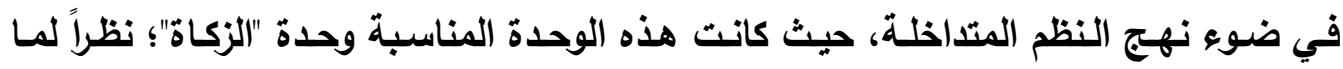

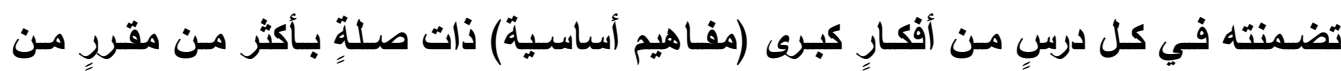
المقررات التي يدرسـها التلاميذ، وقد تم اختيار الصف السـادس الابتدائي؛ نظراً لأن النمو

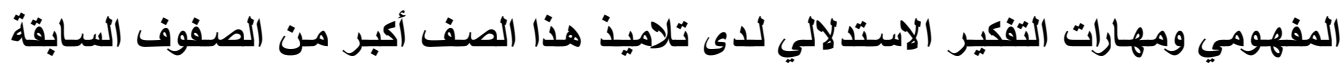

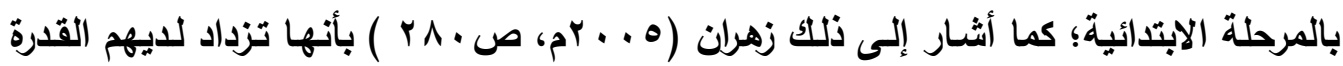

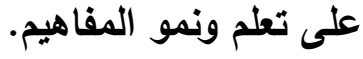


مصطلحات اللدراسة:

تضمنت هذه الدراسة المصطلحات الآتية:

$$
\text { تطوير تلدريس العلوم الشرعية : }
$$

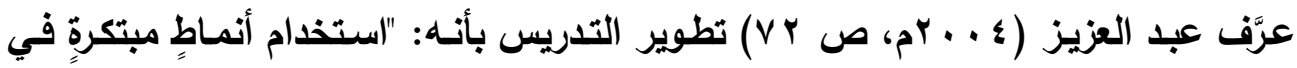

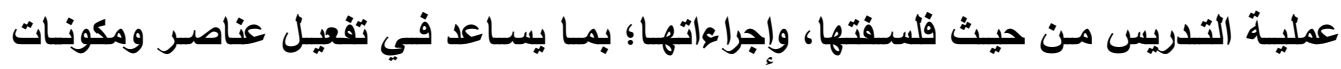
الموقف التعليمس؛ بإدخـال عناصـر جديدة تثري المـادة التعليميـة، وتـدفع التلاميذ للمشـاركة

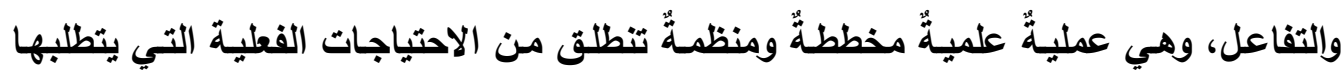

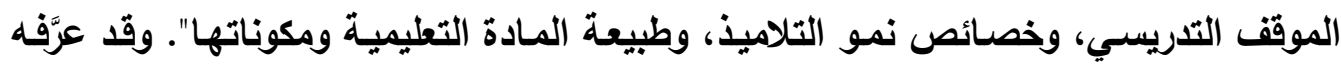

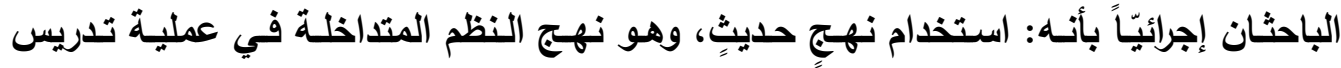

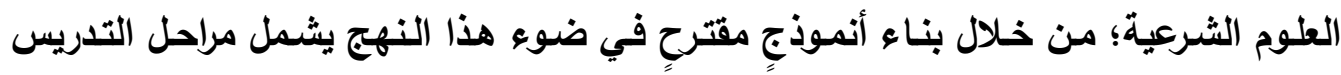
الثلاث: التخطيط، والتتفيذ، والتقويم.

نهج النظم المتلداخلة:

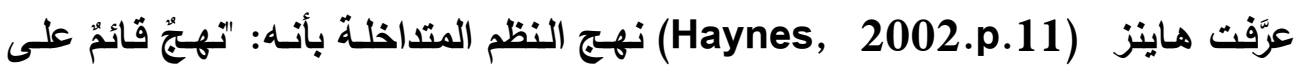
تصميٍٍ يتراوح من درسٍ واحٍِ إلى وحداتِ، ويشتمل على عناصر ذات علاقةٍة بين مادتين أو

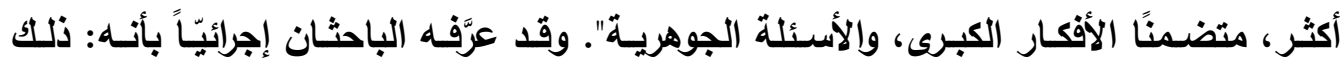

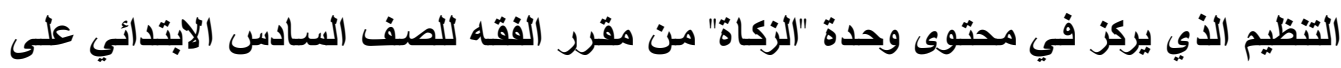

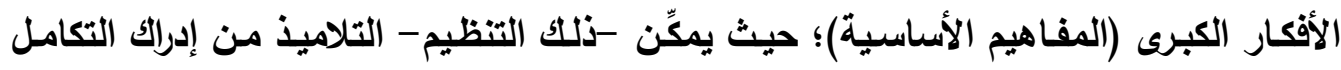
والتداخل بين مقرر الفقه وياقي المقرات، ومن ثم الوصول إلى الإجابة عن الأسئلة الجوهريـة المتعلقة بتلك الأفكار الكبرى (المفاهيم الأساسية) بشكلٍ تكامليٍٍ. وقد تضمن التعريف الإجرائي السابق المصطلحين الآتيين: 1) الأفكار الكبرى (المفـاهيم الأساسية): وقد عرَّفها الباحثّان إجرائيّاً بأنها: تلكت المفـاهيم

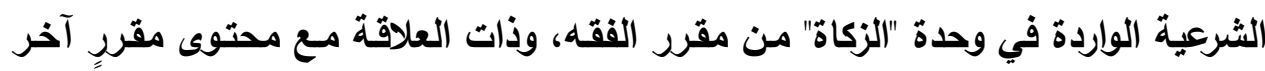
أو أكثر، بالصف السادس الابتدائي.

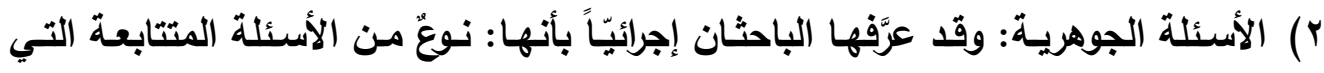

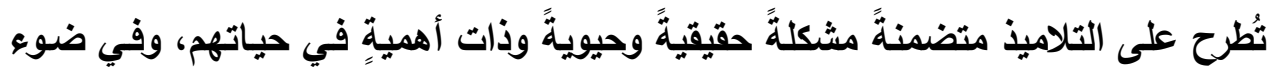


احتياجـاتهم حول الأفكار الكبرى (المفـاهيم الأساسية)؛ حيث تتطلب هذه الأسئلة مـن التلاميذ البحث والاستقصاء؛ للوصول إلى الإجابة عنها.

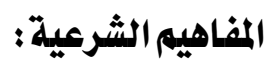

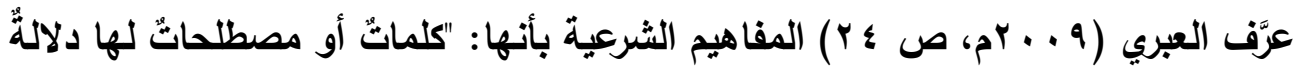

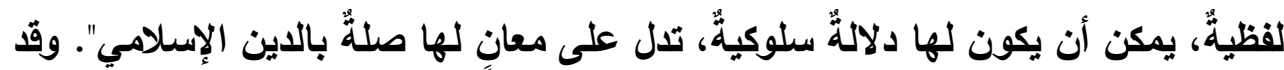

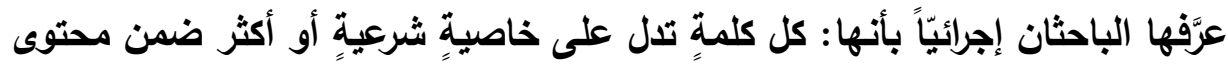
مقررات العلوم الشرعية للصف السادس الابتدائي في الفصل الدراسي الثاني، للعام الدراسي . $1 \leqslant \varepsilon \cdot / 1 \leqslant \mu q$ التفكير الاستلالي:

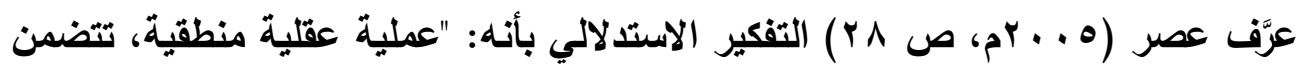
مجموعة من المهارات الفرعية التي تبدو في كل نشاط عقلي معرفي، يتميز باستقراء القاعدة

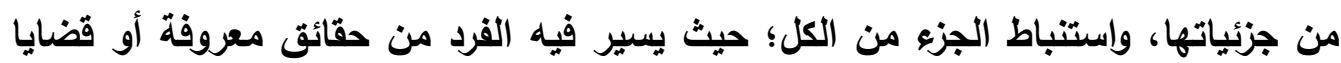
مسلم بصحتها إلى معرفة المجهول ذهنيًا".

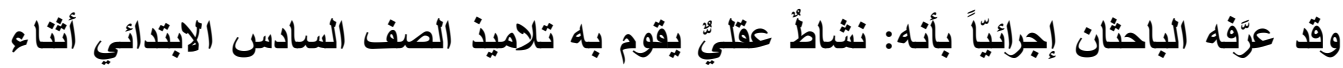

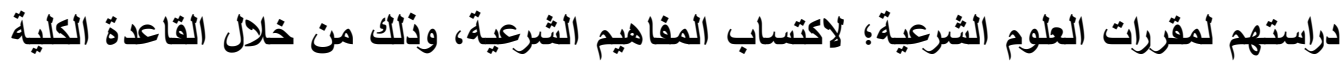
(الاستنباط)، أو الأمثلة الجزئية (الاستقراء)، أو التوصل إلى نتيجةٍ (الاستتتاج)، من خلال الارجات التي يحصلون عليها في اختبار مهارات التفكير الاستدلالي الذي أعدَّه الباحثان. يُعد تعلم العلوم الشـرعية غايـةً نبيلةًة ينبفي للمسـلم السعي إليها؛ فمـن خلالهـا تتكامـل

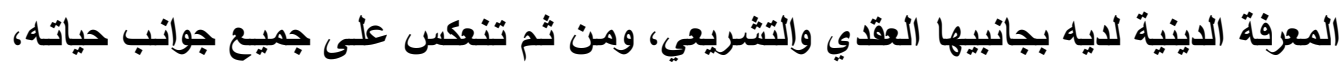
ويستطيع تكوين روئةٍ صحيحةٍ عن الكون، والإنسان، والحياة، ويكتسب معلم العلوم الشرعية أهميته من أهمية هذه العلوم التي تعتبر ملازمةًً لكل مسلمٍ وضروريةً له. له. 
الإطار النظري

يُقصد بالعلوم الشرعية في هذه الدراسة ما كان ضمن إطار المناهج الدراسية في المملكة العربية السعودية؛ حيث أخذت وزلارة التعليم بمصطلح "العلوم الشـرعية"، ومـن ذلك إصدارها

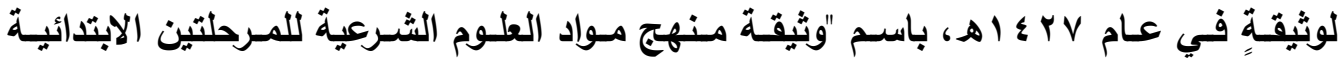
والمتوسطة في التعليم العام"، والمتأمل في مسمى العلوم الثرعية في دول العالم الإسـلامي بهي

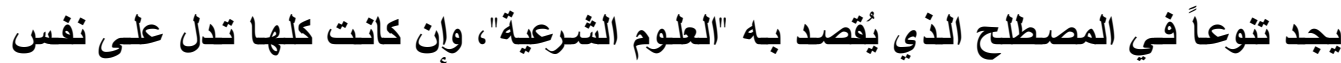
المعنى، ومن ذلك إطلاق مصطلح "التربية الإسلامية"، ومصطلح "التربية الاينية الإسلامية". ومفهوم "العلوم الشرعية" لم يكن معروفاً بهذا اللفظ عند المسلمين في القرون الثلاثة المفضلة؛ حيث إن المجتمع الإسلامي لم يعرف إلا نظاماً واحداً في التربية من خلال كتاب الله

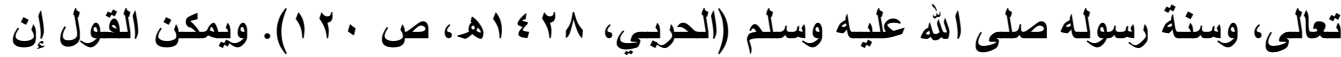

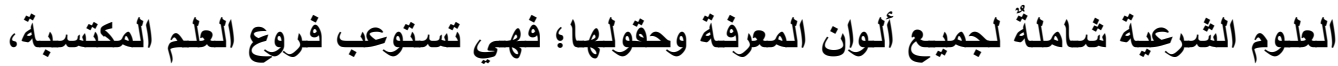

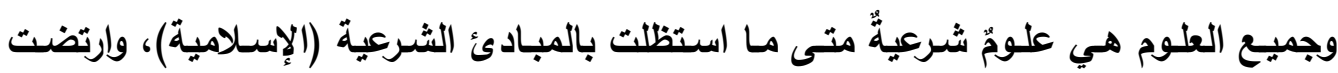

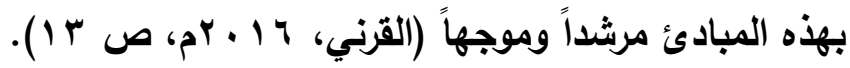
ويُطلق مفهوم "الثريعة" على ما شرعه الله سبحانه وتعالى لعباده من الأحكام، سواءً

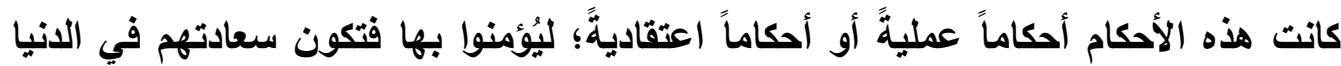

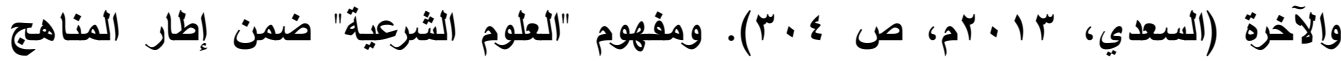
الدراسية لا يخرج عن هذا المعنى إجمالاً، وقد تعددت تعريفاته في الأدبيات التريوية، ومنها ما بأتي:

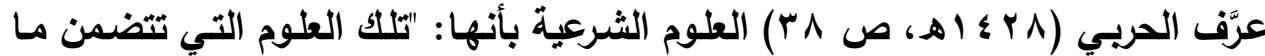
شرعه الله من العقائد والأحكام، وتحث المريع على التزام العبودية لله سبحانه وتعالى، والمتمثلة في القرآن الكريم وعلومـه، والحديث النبوي وعلومـه، والعقيـدة والمـذاهب المعاصـرة، والققهـه

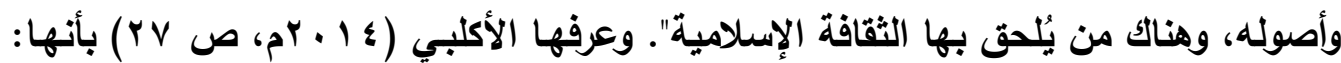

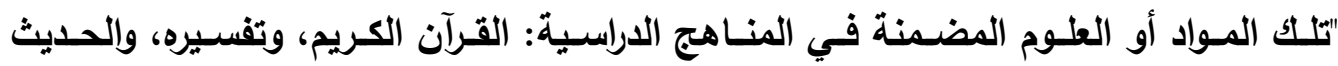
الثريف، والفقه، والتوحيد، والتهذيب، والسيرة النبوية المطهرة". 


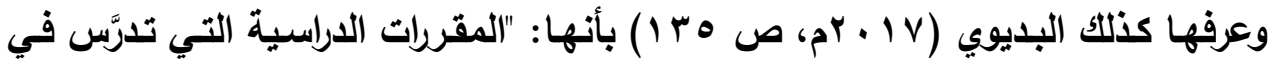

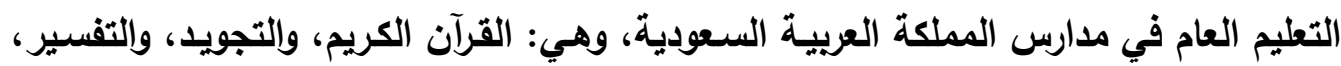
وإلتوحيد، وإلحديث، والفقهه".

أنواع العلوم الشرعية وأقسامها : سـبق ذكر أنـواع العلـوم الشـرعية وأقسـامها ضـمن التعريفـات السـابقة لمفهـوم "العلـوم

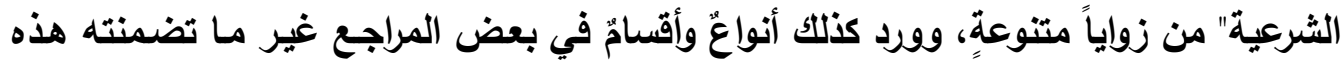

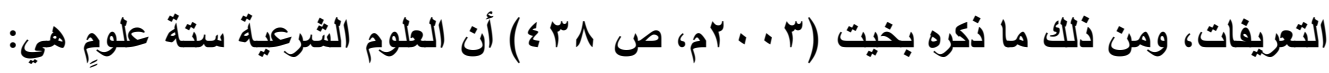
علم القراعات -علم الحديث-التفسير - علم أصول الاين- علم أصول الفقه- علم الفقه.

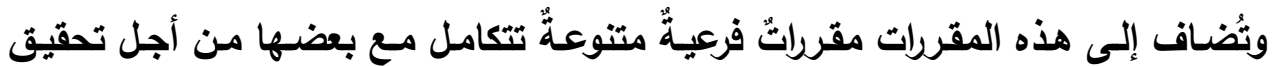

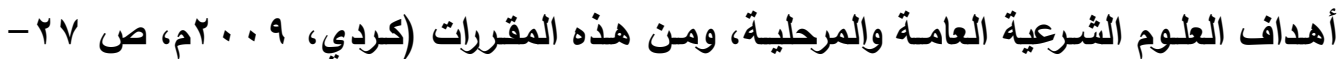
1 ا r ): التجويد - الحديث -التفسير - الثقافة الإسلامية. أهداف تدريس العلوم الشرعية : أولت المملكـة العربيـة السـودية في سياستهاه التعليميـة أهميـةً كبـرى وعنايـةً خاصـةً

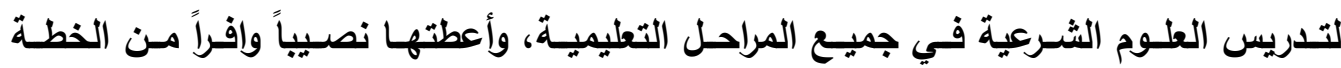

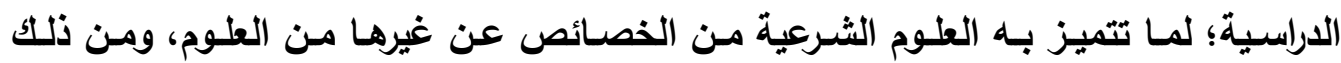
إسهامها في جعل الفرد صالحاً في نفسه، نافعاً لمجتمعه، محققاً لغاية وجوده، فيكون عبداً لله حقًا.

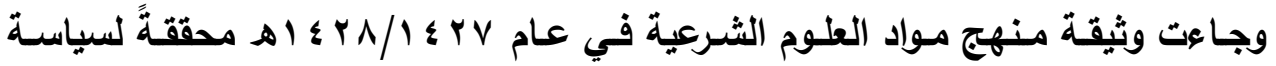
التعليم في المملكة العربيـة السعودية التي تنص على أن "غايـة التعليم فهم الإسـلام فهماً صحيحاً متكاملاً وغرس العقيدة الإسـلامية ونشرها وتزويد الطالب بالقيم والتعاليم الإسـلامية

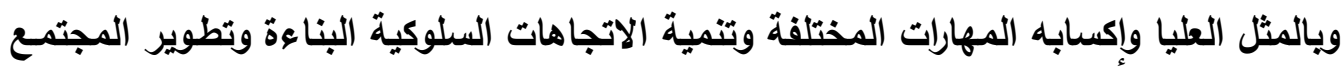
اقتصاديّاً واجتماعيّاً وثقافيّاً وتهيئة الفرد ليكون عضواً نافعاً في بنـاء مجتمعهه" (وزارة التربية

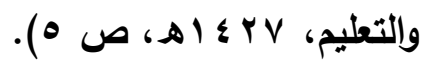




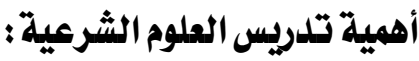

تتبوأ العلوم الثرعية مكانةً كبيرةً بين العلوم المتنوعة ضمن إطار المناهج الدراسية في المملكة العربية السعودية؛ وذلك لأهمية تدريسها للطلاب في جميع المراحل التعليمية، وتعود التئية

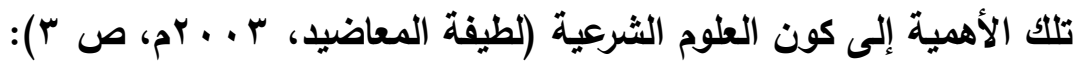
1) تستمد أهدافها ومحتواها وكل ما يتطق بها من دين الإسلام (من القرآن الكريم، والسنة

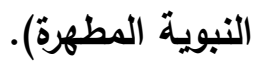

r) تقوم بلدوٍ رئيسٍ في بناء الثخصية المسلمة من جميع جوانبها النفسية والاجتماعية

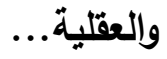

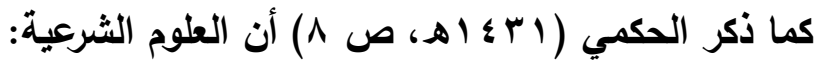

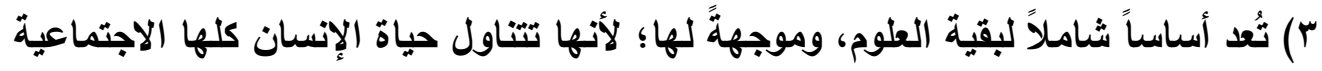

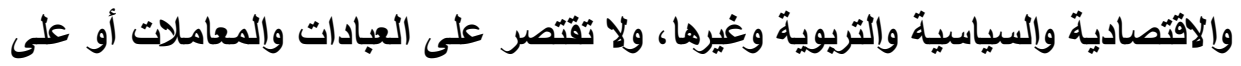
العقيدة فقط.

؛ ) تسهم في تحقيق جميع أهداف المرطلة الابتدائية دون استثناءِ.

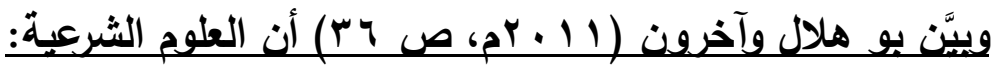

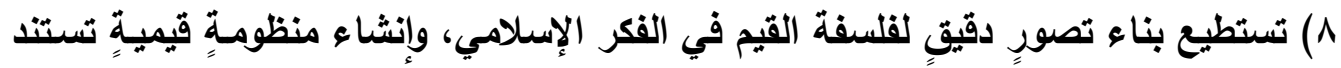

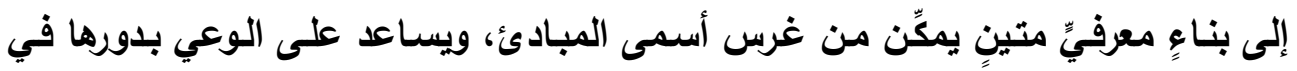
توجيه الفعل الإنساني، وتحقيق الرقي الفردي والاجتماعي. ويتضح مما سبق مدى أهمية العلوم الثرعية، وعلو منزلتها بين العلوم الأخرى، ومن العندي

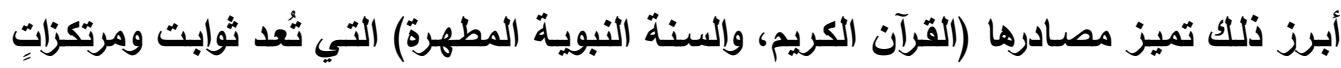
قامت عليها الملكة العربية السعودية، ويذلك استمدت هذه العلوم أهميتها من الإسلام ذاتها.

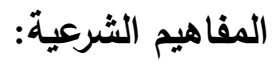
إن المتأمل في الأدبيات والدراسـات والمراجع يجد تنوعاً في المصطلح الذي يُقَصد بـهـ

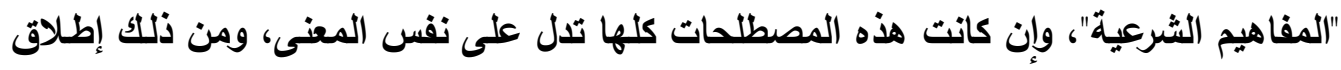

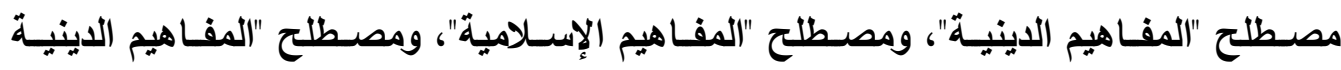
الإسلامية"؛ وهذا التنوع كما تم ذكره سابقاً فيما يتطق بمصطلح "العطوم الثرعية". 
التفكير الاستلالالي:

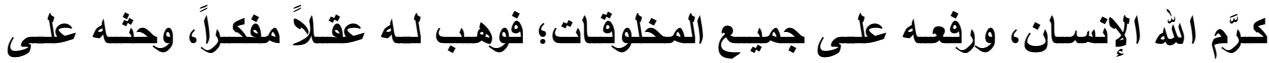
التفكير، والتدبر، والتأمـل، ويُعتبر مفهوم التفكير مـ أهـم المفـاهيم التي دعـا إليهـا القـرآن الكريم؛ وتُعدُّ تنمبة مهارات التفكير -بشكلٍ عامًّ- من أهم أهداف المناهج الحديثة التي تسعى إلى تحقيقها، وتطوير قدرة التلميذ على استخدامها في مجالات الحياة المتتوعة؛ لجعل عملية التعلم ذات معنَى، فيشـارك التلميذ في عملية التعلم بإيجابيةٍة، ويطبق مـا تعلمـه في مواقف

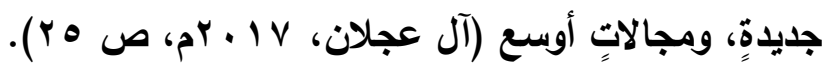
وقد تم تناول ما يتعلق بمحور التفكير الاستدلالي على التحو الآتي:

مفهوم التفكير الاستدلاكي: تعددت تعريفات التفكير الاستدلالي؛ حسب وجهات نظر المعرِّفين له وتخصصاتهم، ومن هذه التعريفات ما يأني:

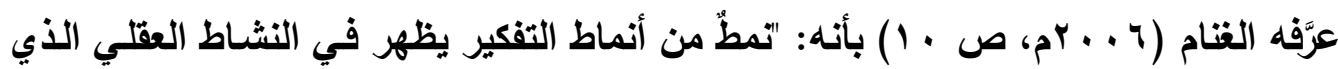
يتجاوز حدود الأدلة المتوفرة، أو المعلومات المقدمـة؛ للتوصل إلى تعميماتٍ (استقراء)، وفي التوصل إلى أحكامٍ خاصةٍ معتمداً على فروضٍ أو مقدماتٍ (استتباط)، وفي التوصل إلى نتيجةٍ من حقائق معينةٍ (قياس)". ويتضح من هذه التعريفات أن التفكير الاستدلالي يقوم على توليد الأفكار، والمعلومـات، والاستخلاص، والاستقراء، والاستنباط، والاستتتاج. أهمية التفكير الاستلالبي:

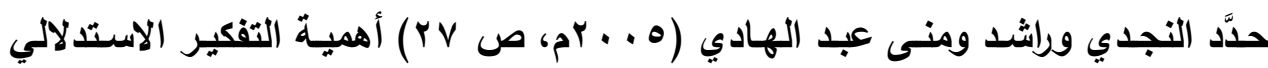
كالآتي: ( ) الاستدلال من أهم ما يحقق أهداف التعليم. r ) الاستدلال يُعد أداة لإثراء العلم. r) الاستدلال من الأمور التي تزيد تحصيل الطلاب. تدريس العلوم الثرعية وتتمية التفكير الاستدلالي: 
هناك طريقتين مهمتين لإكسـاب المفاهيم بشكلٍ عامًّ، والمفاهيم الشرعية بشكلٍ خاصِّ للتلاميذ، وهما: الطريقة الاستتباطية، والطريقة الاستقرائية، وهاتان الطريقتان تمثلان مهارتين من مهارات التفكير الاستدلالي. وهذه الاراسة راعت أهمية الريط بين إكساب المفاهيم الشرعية لتلاميذ الصف السـادس الابتدائي وتثمية مهارات التفكير الاستدلالي لايهم عند تدريس وحدة "الزكاة" من مقرر الفقه،

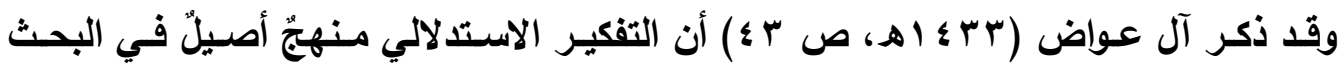

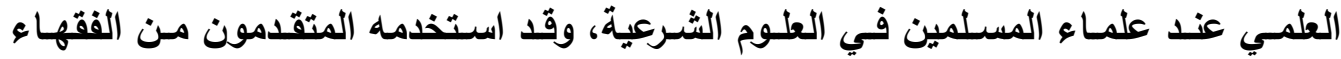
والأصوليين، وكان له النصيب الأكبر في صياغة القواعد الأصولية الفقهية. نهج النظم المتلداخلة: لقد أصبح نهج النظم المتداخلة تقتيـةً مهمةًة في المنـاهج الحديثة وتدريسها؛ حيث إنها يـوازن بين أكثر مـن مـادةٍ دراسيةٍة، ويربط بين المفاهيم على مستوى العلم الواحد، وعلى مستوى عدة علومٍ، ومن ثم فهو يجعل تعلم التلاميذ ذا معنَّ.

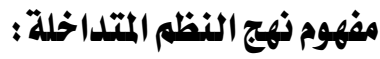

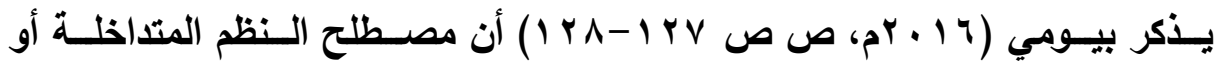
الاراسات البينية (Interdisciplinary) يتكون من مقطعين أساسيين هما:

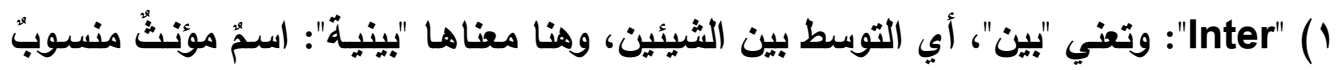

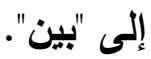
r (discipline" (التعني "النظام"، أي التأليف بين الأثشياء وضم بعضها إلى البعض الآخر، مع الترتيب والاتساق، وهنا معناها "مجالٌ دراسيٌّ معينٌ".

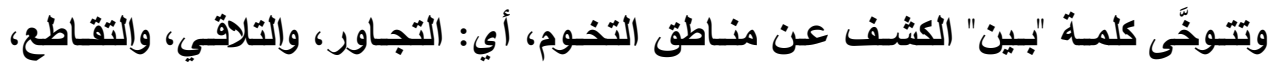
وإلتشابك، والتقارب بين العلوم (صالحين، 9 1 1 ـ بم). وأمسا مصطلح "Approach" فيعني: نهُجج، أو مدخل، أو أسـلوب، أو منحسى (قاموس ومعجم المعاني، • 1 • ب م).

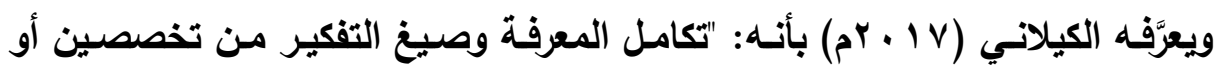

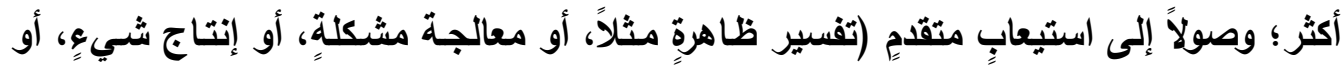
إثارة تساؤلاٍٍ جديدةٍ) لا يمكن لوسائل تخصصٍِ منفردٍ أن تحققه". 


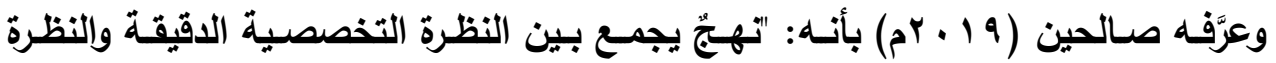

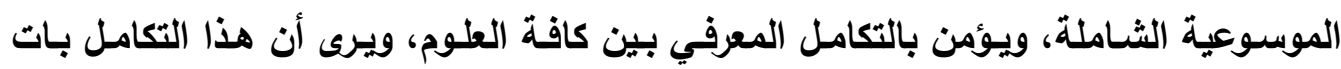
ضرورةً من ضرورات المنهج العلمي النافع في هذا العصر". عناصر العملية التعليمية في ضوي نهج النظم المتلاخلة:

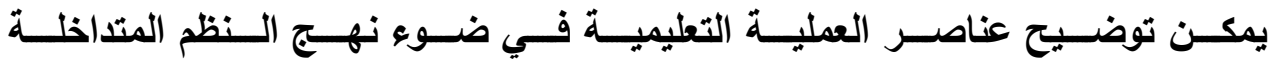
(Interdisciplinary Approach) ( ) تخطيطالمـنهج : ينبغـي أن يُخطط المـنهج في ضـوء التـاخل والتكامل بـين التخصصـات المتنوعة؛ بحيث تُلفى الحدود الفاصلة وتتلاشسى بين تلك التخصصات، ويتم طرح أسئلةٍ جوهريةٍ حول مشكلاتٍ حقيقيةٍ وحيويةٍ وذات أهميةٍ في حياة التلاميذ، وتؤدي هذه الأسئلة إلى الاستقصاء والجدل للوصول إلى الأفكار الكبرى (المفاهيم الأساسية).

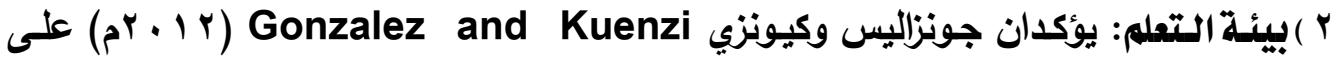

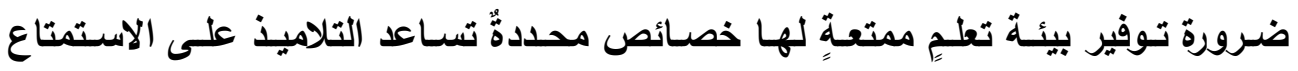

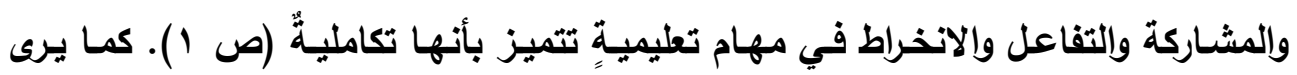

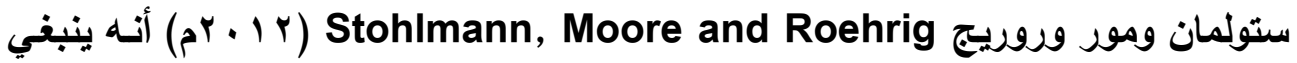
تصميم بيئة تعلمٍ شموليةٍ وحقيقيةٍ تركز على المشكلات والتطبيقات التي صاغتها المعرفة السـابقة لـدى التلميذ في العـالم الحقيقي، والاستفادة مـن المجتمـع المحلـي في تحقيـق أهداف التعلم، ومعايشة التجرية الواقعية في ظل الاحتياجات الحقيقية للمجتمع (ص 9 ؟).

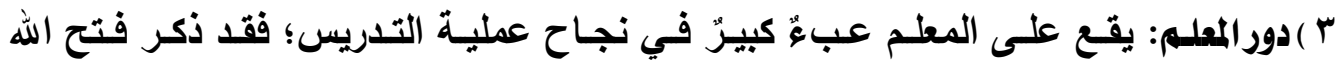
( أن المعلم هو المسؤول الأول والأخير عن إظهار التفاعل

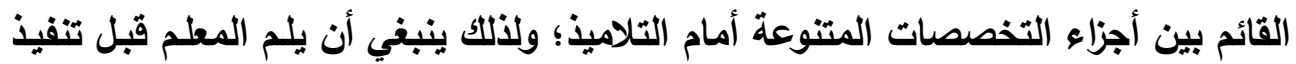
عملية التدريس بالأدوار الآتية:

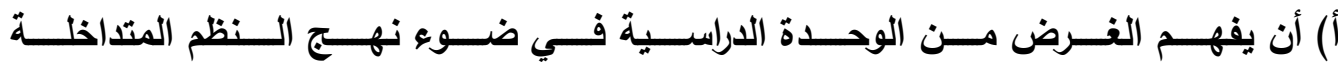
بشكلٍ واضحٍ. (Interdisciplinary Approach) ب) أن يعرف أنها مطالَبٌْ بالتشعب في المعرفة، والسـعي لتثقيف نفسـه باستمرارِ، والبعد عن الاوامة الروتينية في أداء رسالته. 


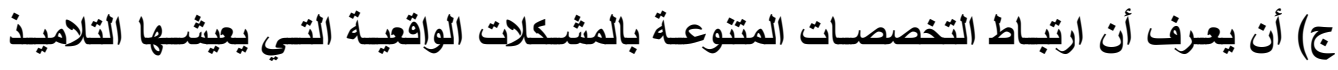
يفرض عليه اتباع طرائق للتدريس وإستراتيجياتٍ جديدةٍ، بحيث تعتمد على تنمية التفكير لاى التلاميذ؛ لإيجاد حولٍ غير تقليديةٍ للمشكلات.

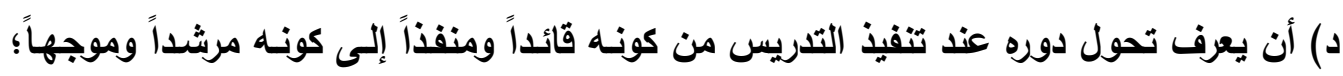

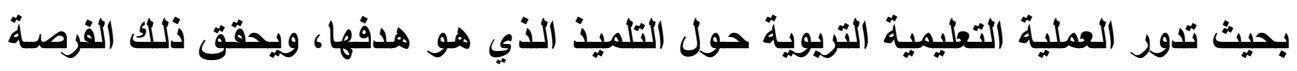
للتلميذ في مواجهة المشكلات، والتجرية وإلخطأ، وتعديل السلوك.

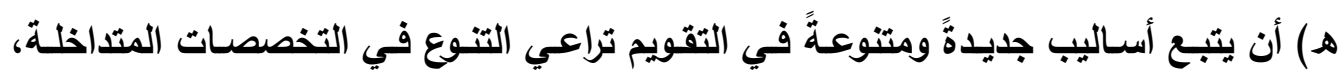

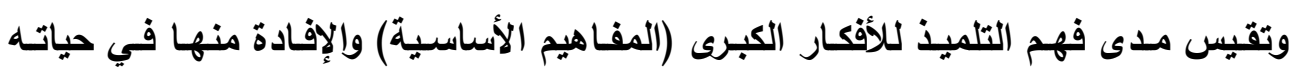

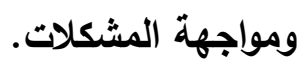

وذكر أورتيقا وأورتيقا Ortega, \& Ortega, 2005) أنه يتعين على المعلم:

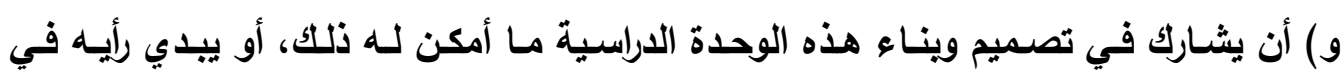

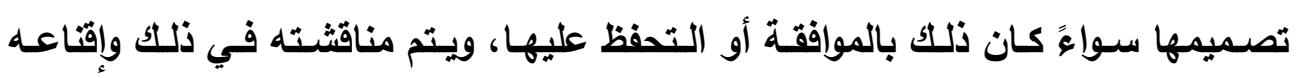
بأهميتها ودورها في تحقيق أهداف العملية التعليمية.

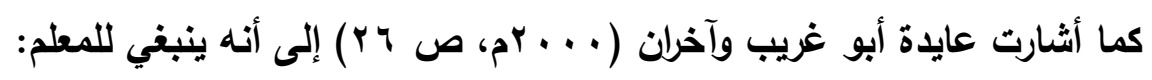

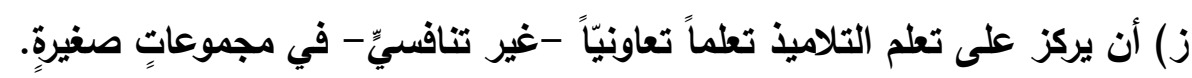
ح) أن يتيح الفرصة للتلاميذ للتعبير عن أنفسهم. أمسا دينيمي وأدا(Deneme and Ada , 2012.p.885) فقد ذلكرا أنسه ينبغي

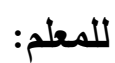

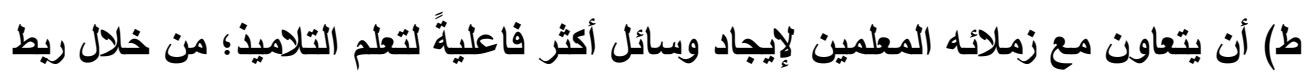

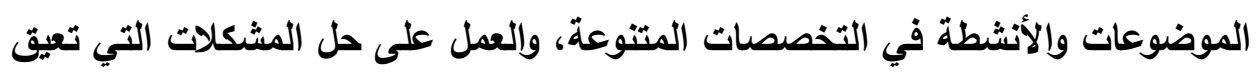

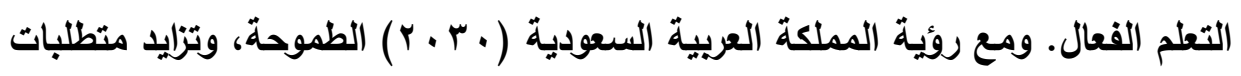

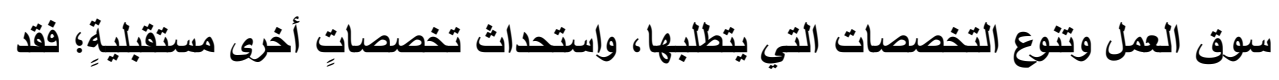

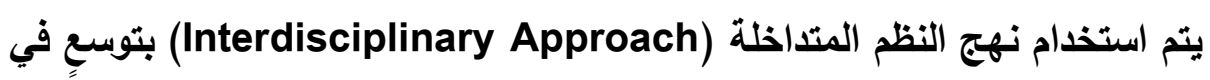

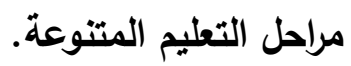


العلاقة بين نهج النظم المتلاخلة وإكساب المفاهيم الشرعية وتنمية التفكير الاستدلالي: تمـت الإشـارة إلى بعض جواتب العلاقِة بين المفـاهيم -بشكلٍ عـامٍ والمفـاهيم الشـرعية بشكلٍ خاصٍٍ - وإلتفكير الاستـلالي ضمن المحورين الثاني والثالث من الإطار النظري -وهمـا:

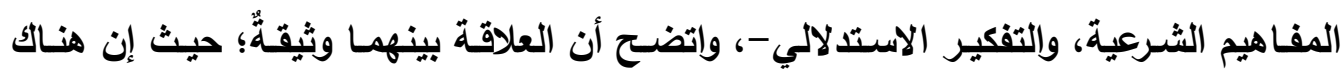

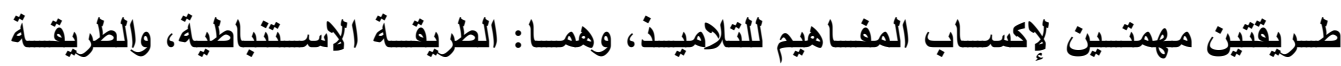
الاستقرائية، وهاتان الطريقتان تمثلان مهارتين من مهارات التفكير الاستدلالي.

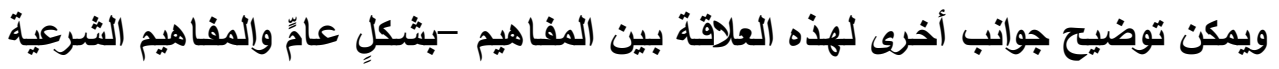
بشكلٍ خاصٍٍ - والتفكير الاستدلالي على التحو الآتي: - أهم مثيرات التفكير السليم هي المفاهيم، والتي تساعد في تذكر المعرفة، وتنظيم الخبرة ومتابعة تطورها في مصادرها (Carroll, 2000, p.187). - تساعد المفاهيم على تنمية المهارات العقلية لدى التلاميذ أثناء عملية اكتساب المفاهيم، كمهارة الربط، وإلتظيم، والتمييز، وتحديد الخصائص المشتركة، وتحديد الصفات الرئيسة

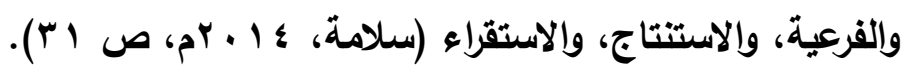
- القواعد والمفاهيم التي يتوصل لها التلميذ بنفسه عن طريق التفكير الاستدلالي ستبقى معه

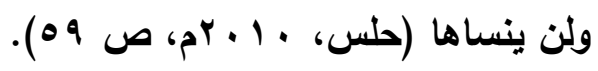
- يُسـتخدم التفكير الاسـتدلالي في حسالات تكوين المفهوم، ويُعدُ أساسـاً للتطور المعرفي؛ لارتباطه الموجب بتحصيل التلاميذ، وإظهاره لأعلى معاملات الارتباط بدرجاتهم في كثيرٍ

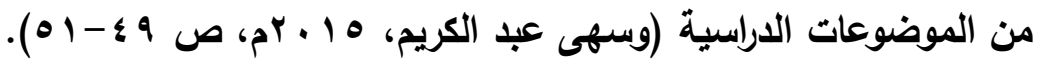

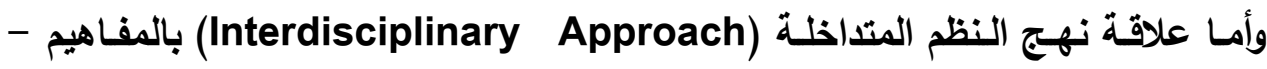
بشكلٍ عامًٍ والمفاهيم الثرعية بشكلٍ خاصٍٍ - فيمكن توضيحها على النحو الآتي: - يمكّن من إبراز الترابط وإلتكامل بين فروع المعرفة المتنوعة من خلال تدريس المفاهيم ، حيث يفهم التلميذ الصورة الكبيرة لمفهومٍ معينٍ ضمن سياق تخصصـاتٍ علميةٍ متنوعةٍ

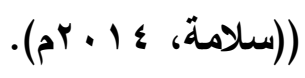

- مساعدة التلاميذ على البحث والاستقصاء؛ للحصول على معلوماتٍ جديدة ، كما تُسـهم في توظيف الخبرات التعليمية في المواقف التعليمية الجديدة (سعادة، 1 ا ـ r). 
- يُعتبر نهج النظم المتاخلة (Interdisciplinary Approach) مهمّاً في جميع مراحل

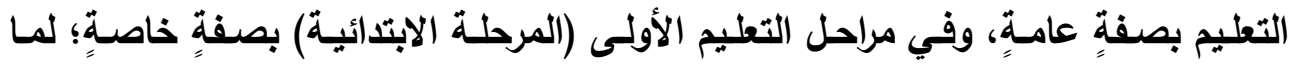

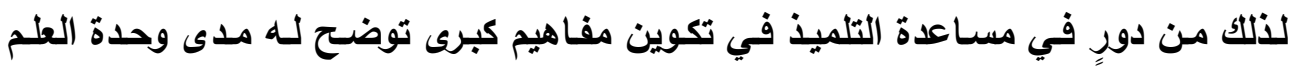
وترابط مفاهيمه، وهذا يساعد التلميذ في تجنب تكوين مفاهيم خاطئة في المراحل التعليمية التالية (Novak and Gowin, 2000, p.26). - يؤدي نهج النظم المتداخلة (Interdisciplinary Approach) إلى تنظيم المعرفة (لئة

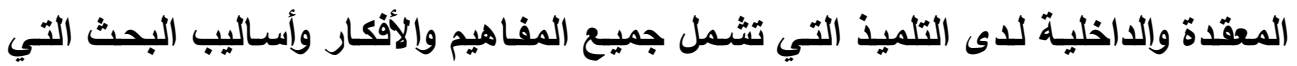
تثكل مجال المعرفة وتعطيها معنَى (Ivanitskaya, Clark, Montgomery and .Primeau, 2002, p.101) - يُعتبر بناء مناهج العلوم الثرعية بالاعتماد على المفاهيم الثرعية بناءً متتابعاً ومترابطاً في المراحل الدراسية، وسيريطها بالمناهج الدراسية الأخرى؛ ليتكامل البناء المعرفي، ويتم

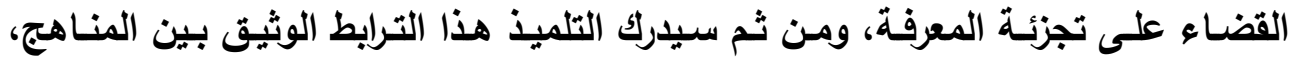

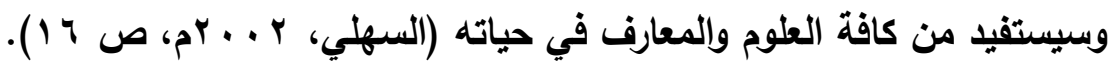

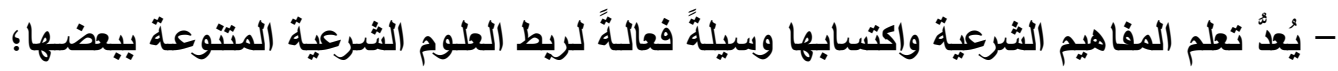

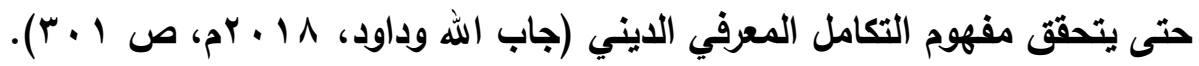
وأمسا علاقـة نهـج النظم المتداخلـة (Interdisciplinary Approach) بـالتفكير الاستدلالي فيمكن توضيحها على النحو الآتي: - يمكن تنمية التفكير الاستدلالي من خلال استخدام طرائق التدريس وإستراتيجياته ونمانجه الإنها

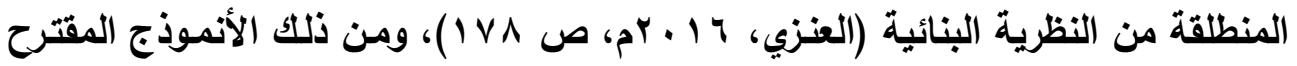
في ضوء نهج النظم المتداخلة (Interdisciplinary Approach) في هذه الدراسة؛ حيث ينطلق من النظرية البنائية.

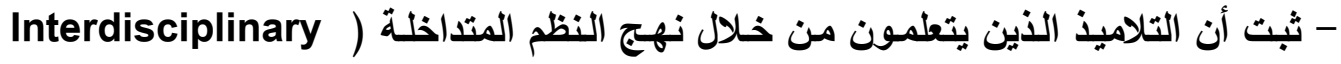

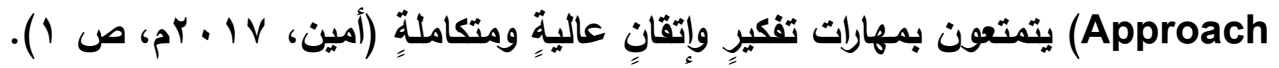

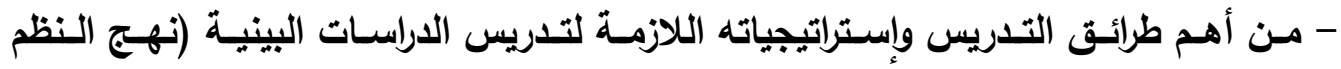
المتداخلة) طريقتا الاستدلال: الاستتباط، والاستقراء -اللتان تمثّلان مهارتين من مهارات

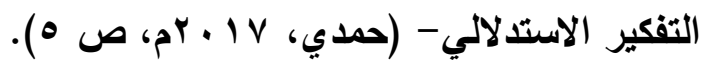


- يُسهم التدريس في ضوء نهج النظم المتاخلة (Interdisciplinary Approach) في تطوير مسـتويات التفكير العليـا التـي تثــل: حريـة التقصس، والتفكير الناقد، والتفكير الاستدلالي، والتفكير التركيبي (You, 2017, p.67).

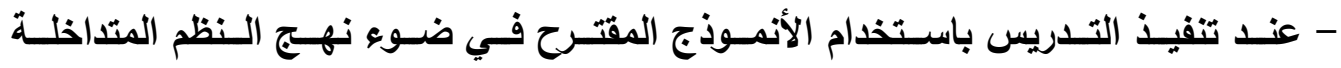
(Interdisciplinary Approach)؛ فإن التلميذ يمارس مهارتَي الاستتباط والاستقراء أو إحداهما في المراحل الآتية: (إثارة انتباه التلاميذ للارس، واستكشـاف احتياجات التلاميذ في الارس، والبحث والاستقصاء)، كما يمارس التلميذ مهارة الاستتتاج في مرحلة (توضيح

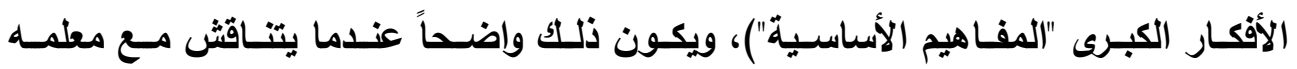
وزملائه، وكذلك يمسارس مهارات العلم كالملاحظة والتفسير والتتبؤ في المراحل السـابقة؛ مما يؤدي إلى تنمية مهارات التفكير الاستـلالي لديه، ويمكن القول بأن التلميذ يمارس

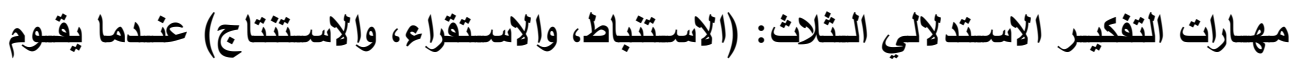
بتلخـيص الــرس في خـرائط مفـاهيم ضـمن مرحلـة (توضـيح الأفكار الكبـرى "المفـاهيم (الأساسية").

\section{اللدراسات السابقة :}

تناول جزء الدراسـات السـابقة العديد من الدراسـات السـابقة العربيـة والأجنبية ذات الصلة بموضوع الدراسة، وذلك من خلال أربعة محاور هي: ( ) دراسات تناولت تدريس العلوم الثرعية. r r باسات تناولت المفاهيم الشرعية. r) دراسات تناولت التفكير الاستدلالي. ع) دراسات نتاولت نهج النظم المتداخلة. 


\section{المحور الأول : دراسات تنتاولت تلدريس العلوم الشرعية:}

تعدلت الداسات التي تناولت تلديس العلوم الثرعية في جميع مراحل التعليم، ويُلاحظ أن معظم تلكت الدراسـات يتطق بجاتب معوقات (مشكلات) التدريس، وفي هذا المحور تم عرض بعض الدراسات على النحو الآتي:

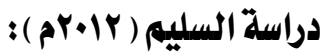

حيث قامت الباحثة بدراسِةٍ بغنوان: "معوقات استخدام إستراتيجية التعليم المتمايز في تدريس مقرات العلوم الثرعية في المرحلة الابتدائية من وجهة نظر المعلمـات في مدينة الرياض"، وهدفت الدراسة إلى تعرُّ معوقات استخدام إستراتيجية التعليم المتمايز في تدريس مقررات العلوم الثرعية في المرحلة الابتدائية من وجهة نظر المعلمات في مدينة الرياض، واتبعت الدراسة المنهج الوصفي المسحي، وتمثلت أداتها في استبانةٍ موجهةٍ لعينة الدراسة فئة

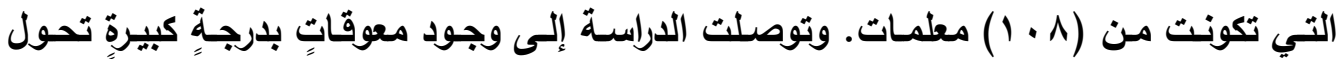
دون استخدام إستراتيجية التعليم المتمـايز في تدريس مقررات العلوم الثرعية في المرحلة

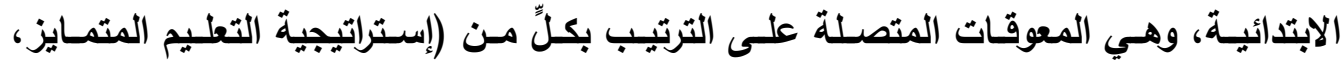
والبيئة، والتنظيم، والطالبات).

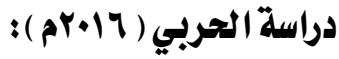
حيث أعدَّ الباحث دراسةًَ بعنوان: "واقع استخدام التعليم المتمازج في تدريس مقررات

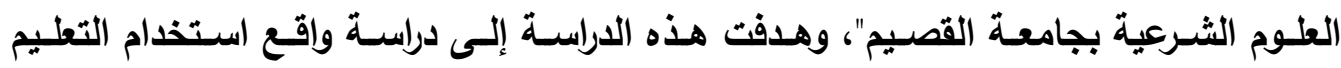

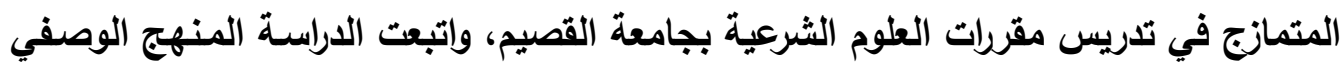

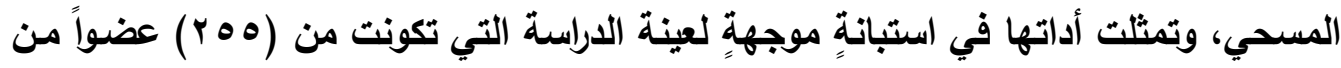
أعضاء هيئة التدريس في جامعة القصيم. وتوصلت الدراسـة إلى مجموعةٍ من النتائج، كان من أبرزها: اتفاق عينة الدراسة بدرجةٍ كبيرةٍ على كلٍّ من: معرفة أدوات التعليم المتمازج التي

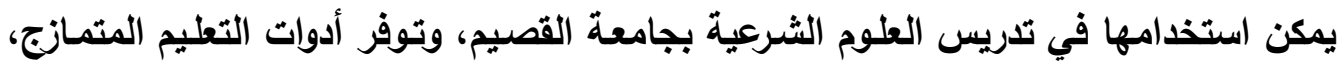
ومعرفة فوائد استخدامه.

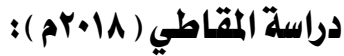

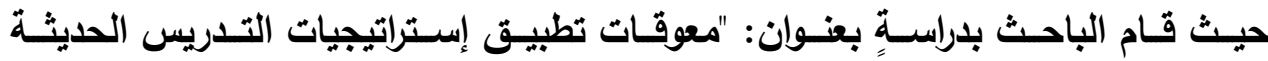

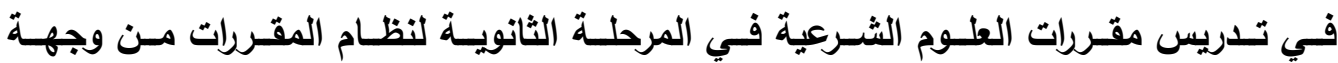


نظـر المعلمـين"، وهـدفت هـــه الدراســة إلـى الكشـف عـن معوقـات تطبيـق إســراتيجيات

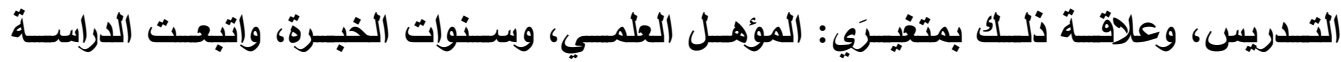

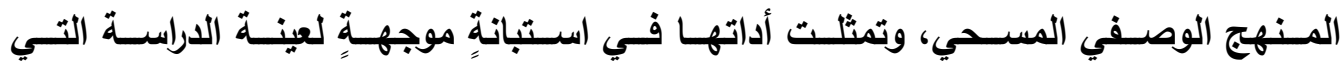

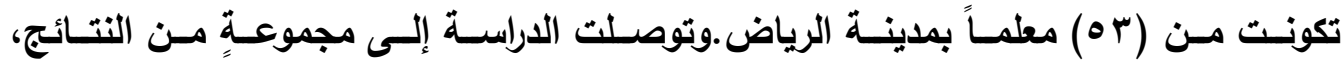

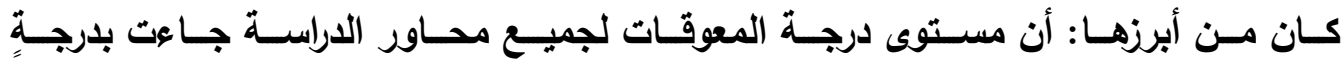

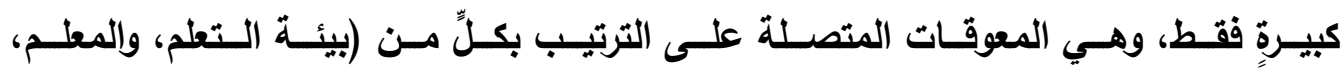

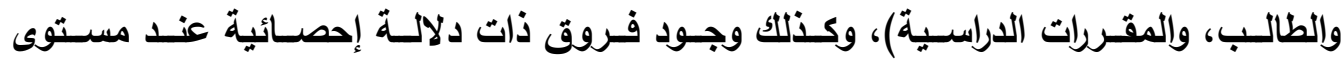

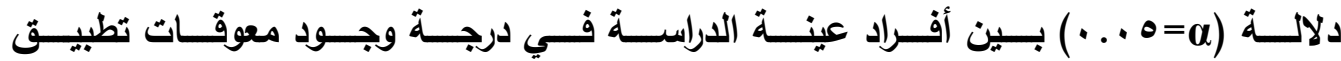

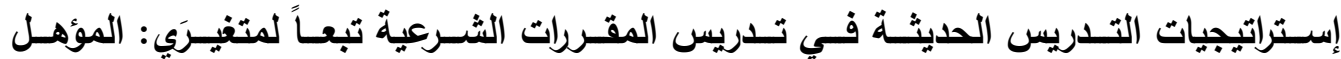
العلمي، وسنوات الخبرة.

دراسة الناجي (19.19م )؛ حيث أجرى الباحث دراسةً بعنوان: "إستراتيجيات وطرائق تدريس العلوم الثرعية من خلال البحوث التريوية"، وهدفت هذه الدراسة إلى تحديد إستراتيجيات وطرائق

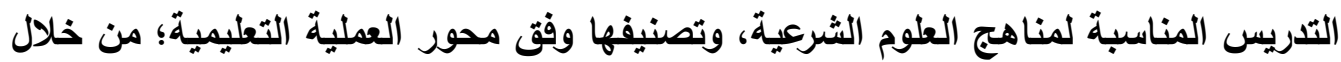
مجموعةٍ من قواعد البيانات الرقمية للبحوث التربوية في الدول العربية، واتبعت الدراسة المنهج الوصفي التحليلي، وتمثلت أداتها في بطاقة تحليلٍ تم تطبيقها على عينة بلفت

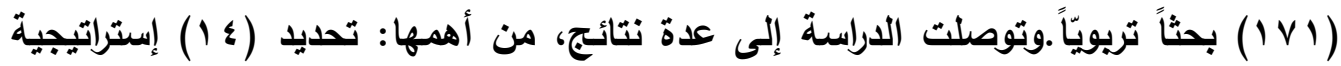

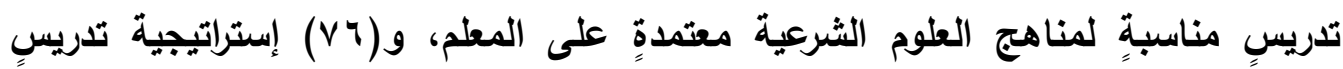
معتمدةٍ على المتعلم، و( ؛ ) إستراتيجيات تدريسٍ معتمدةٍ على المعلم وإلمتعلم معاً. 


\section{المحور الثاني : دراسات تناولت المفاهيه الشرعية:}

هناك دراساتُّ متنوعةٌ تناولت المفاهيم الثرعية، ولكن تلكت الدراسات تباينت في تسمية "الدفاهيم الثرعية" للالالة على نفس المغنى؛ ومن ذلك التباين تسميتها: "المفاهيم الثرعية"،

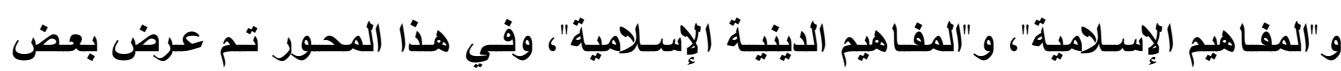

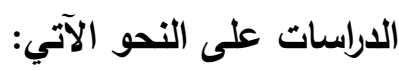

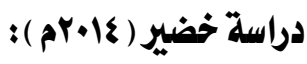

حيث أجرى الباحث دراسـةً بعنوان: "أثر أنمـوذج ميرل تتسـون في اكتسـاب المفـاهيم

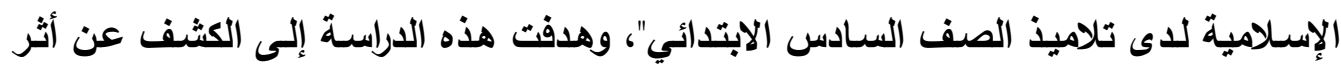

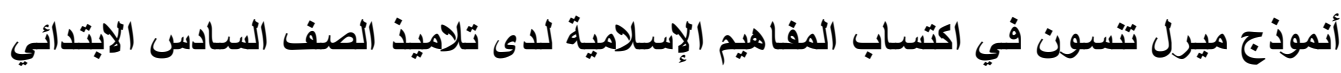

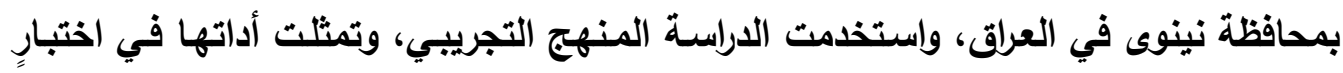

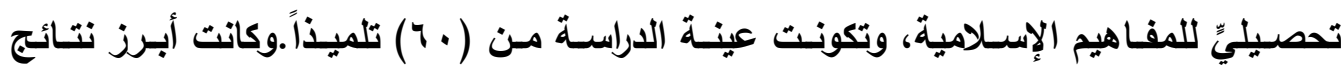
الاراسة كالآتي: وجود فروق ذات دلالة إحصائية بين متوسطي درجات تلاميذ المجموعتين

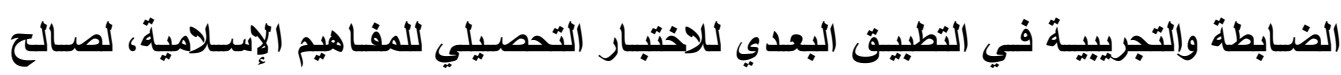
المجموعة التجريبية. دراسة حسن (10 مrم ): قام الباحث بدراسةٍ بغوان: "أثر اختلاف مستوى التفاعل في القصة الإكترونية وموقعها

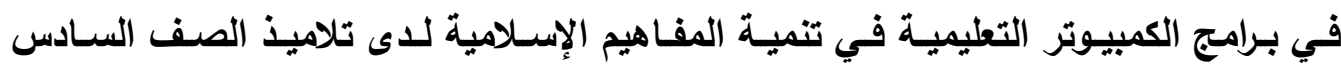

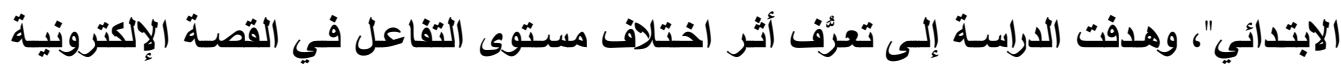

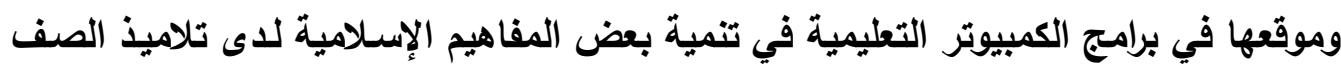

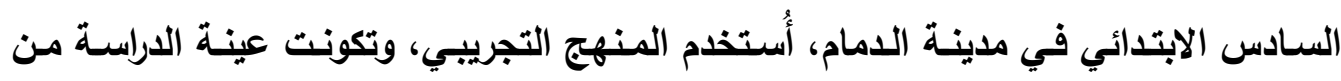

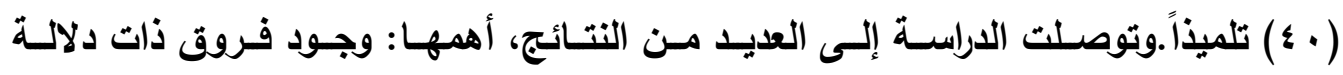

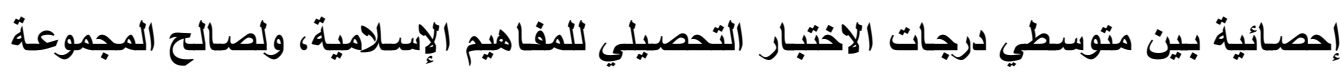
التجريبية التي درست باستخدام برنامج القصة الإكترونية بمستوى تفاعلٍ متقام. 
دراسة محمود وسيلد وعمران ( 17 مبم ) ؛

حيث أعدَّ الباحثون دراسةً بعنوان: "فاعلية إستراتيجية النمذجة المدعومـة بالويب كويست في عـلاج الفهم الخطأ لبعض المفـاهيم الاينيـة الإسـلامية لـدى تلاميذ المرحلـة الإعداديـة"، وهدفت الدراسـة إلى تعرف فاعلية إستراتيجية النمذجة المدعومـة بالويب كويست في علاج بعض المفاهيم الاينية الإسلامية الخاطئة لاى تلاميذ الصف الثاني الإعدادي بمدينة القوصية في مصر، أُستخدم المنهجين: الوصفي، وشبه التجريبي، وتمثلت أدواتها في بطاقةٍ لتحليل

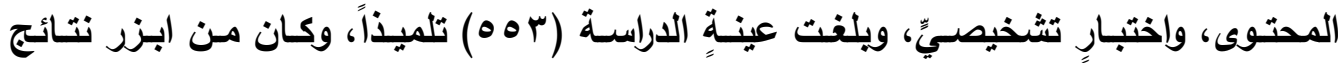
الاراسـة: وجود فروق ذات دلالة إحصائية عند مستوى دلالـة ( درجات تلاميذ مجموعة لاراسـة في التطبيقين القبلي والبعدي للاختبار التحصيلي، ولصـالح التطبيق البعدي.

دراسة الخوالدة ( Vا.مrم ) ؛ حيث أجرى الباحث دراسـةً بعنـوان: "أثر استخدام التقويم الحقيقي في اكتســاب طلاب الصف الأول الثانوي للمفاهيم الثرعية"، وهدفت هذه الاراسـة إلى الكثف عن أثر استخدام التقويم الحقيقي في اكتساب طلاب الصف الأول الثانوي في محافظة المفرق بـالأردن للمفاهيم

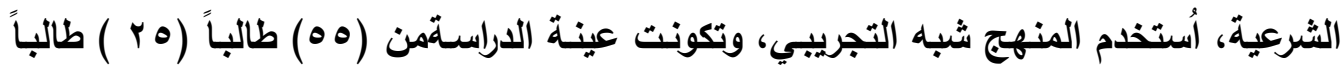

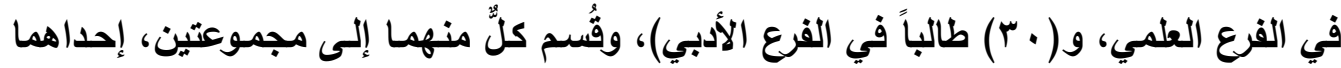
ضابطة، والأخرى تجريبية. وأظهرت نتائج الدراسة وجود فروق ذات دلابلة إحصائية عند مستوى دلالة (ه=ه ه . . ) بين متوسطي درجات طلاب المجموعتين الضـابطة والتجريبية في التطبيق البعدي للاختبار التحصيلي، ولصالح المجموعة التجريبية.

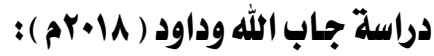
قام الباحثان بدراسةٍ بعنوان: "أثر إستراتيجية خرائط المفاهيم في اكتساب المفاهيم الثرعية والتحصيل الدراسي للطلاب الناطقين بغير العربية"، وهدفت الدراسـة إلى تعرُّف أثر استخدام

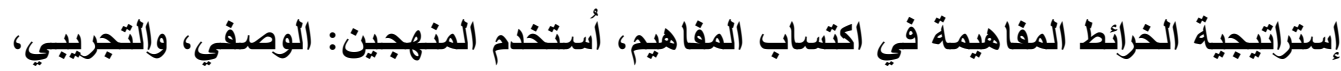

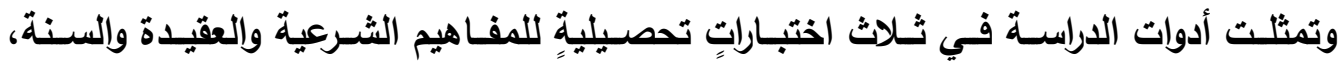

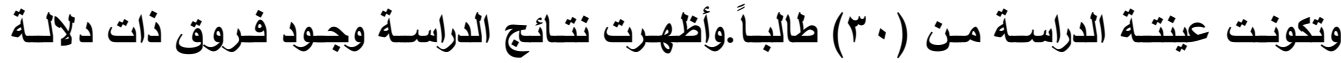


إحصائية بين متوسطي درجات طلاب المجموعتين الضابطة والتجريبية في التطبيق البعدي للاختبار التحصيلي، ولصالح المجموعة التجريبية.

\section{المحور الثالث : دراسات تناولت التفكير الاستلالي:}

في هذا المحور عُرضت بعض الدراسـات التي تناولت التفكير الاستتلالي في الصف

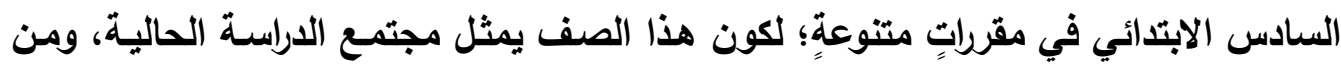
تلك الدراسات ما يأتي:

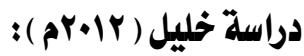

حيث قامت الباحثة بدراسةٍ بعنوان: "أثر استخدام برنامج كورت في تحصيل العلوم ويقاء أثر التعلم وتتمية التفكير الاستدلالي لدى تلاميذ الصف السادس الابتدائي"، وهدفت الدراسـة إلى تعرُف أثر استخدام برنامج كورت في تنمية مهارات التفكير الاستدلالي للى تلاميذ الصف لأل

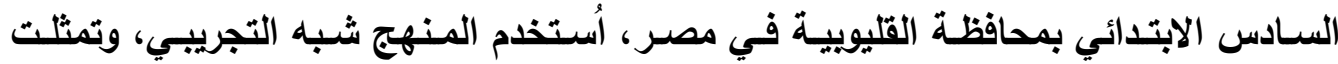

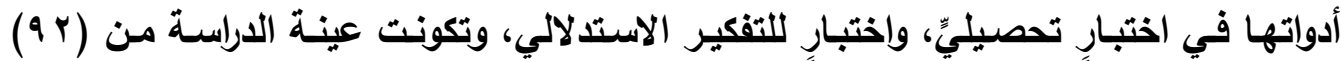

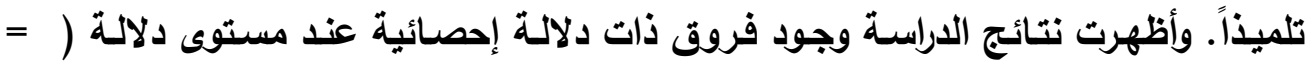

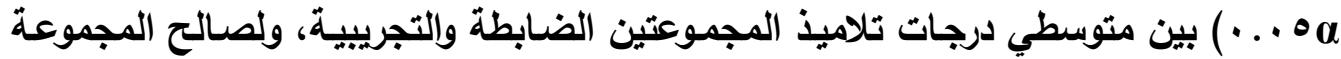
التجريبية.

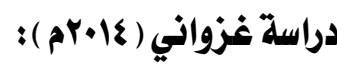
أعدَّ الباحث دراسةً بعنوان: "أثر تدريس العلوم في ضوء برنـامج كورت CoRT على

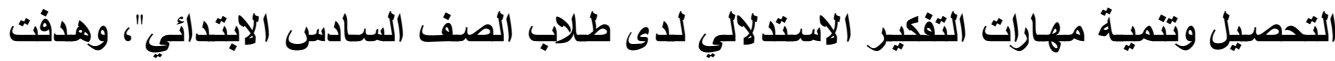
هذه الاراسة إلى تعرُّف أثر تدريس العلوم في ضوء برنامج كورت في التحصيل وتنمية مهارات

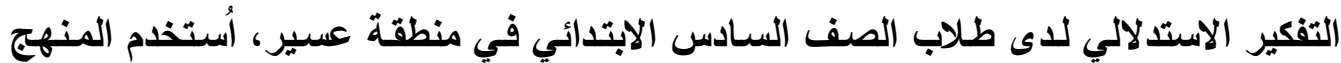
شبه التجريبـي، وتمثلت أدوات الاراسـة في اختبارٍ تحصيليِّ، وإختبارٍ للتفكير الاستـلالي،

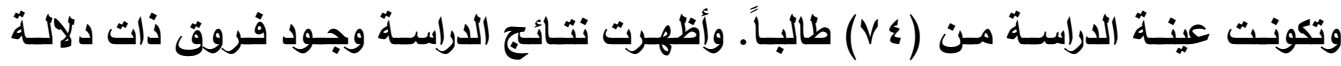
إحصائية عند مستوى دلالة (a = ه . . .) بين متوسطي درجات طلاب المجموعتين الضـابطة والتجريبية، ولصالح المجموعة التجريبية. 
دراسة الفضيلي ( 10 مrم ) ؛

وأجرى الباحث دراسةً بعنوان: "فعالية تدريس العلوم باستخدام أنموذج التعلم التوليدي

في تعديل التصورات البديلة وتثمبة مهارات التفكير الاستدلالي لدى طلاب الصف السـادس الابتدائي"، وهدفت الدراسة إلى تعرُّف فعالية تدريس العلوم باستخدام أنموذج التعلم التوليدي في تعديل التصـورات البديلة لـى طلاب الصف السـادس الابتدائي في مدينة أبها، وتتميـة مهارات التفكير الاستدلالي لايهم، أستخدم المنهج شبه التجريبي، وتمثلت أدواتها في اختبارٍ

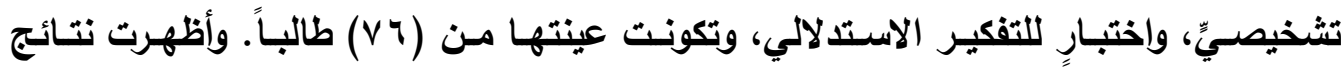

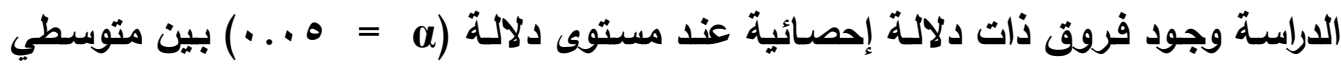
درجات طلاب المجموعتين الضابطة والتجريبية، ولصالح المجموعة التجريبية. دراسة محمد ( ) قام الباحث بدراسـة بعنوان: "قاعليـة إستراتيجية مقترحة وفق التسريع المعرفي في تحصيل مـادة الرياضسيات والتفكير الاســدلالي لتلاميذ الصـف السـادس الابتـائي وكفـايتهم المعرفية المدركة"، وهدفت هذه الاراسـة إلى تعرُّف فاعلية إستراتيجية مقترحة وفق التسريع المعرفي في تحصسيل مـادة الرياضـيات والتفكير الاسـتلالي والكفايـة المعرفيـة المدركة لدى تلاميذ الصف السـادس الابتدائي في محافظة البصرة بالعراق، أستخدم المنهجين: الوصفي، والتجريبي، وتمثلث أدواتها في اختبارٍ تحصيليٍ، واختبارٍ للتفكير الاستدلالي، واختبارٍ للكفايـة المعرفية المدركة، وتكوتت عينتها من (اب) تلميذاً. وأظهرت نتائج الدراسـة وجود فروق ذات

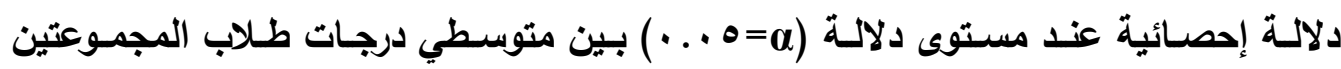
الضابطة والتجريبية، ولصالح المجموعة التجريبية.

دراسات تناولت زهج النظم المتلداخلة:

تناولت عدة دراساتٍ أجنيِةٍ نهج النظم المتداخلة، وأمـا على صعيد الدراسـات العربية فلا يوجد -على حد علم الباحث- سوى دراسة جبر ( آ م ب م)، وفي هذا المحور تم عرض بعض تثلك الاراسات الأجنبية مع هذه الاراسة العربية على النحو الآتي: 
دراسة بارك وميلز) (Park and Mills, 2014) :

حيث قام الباحثان بدراسةٍ بعنوان: "تعزيز التعلم بالنظم المتاخلـة مـع نظام إدارة التعلم"،

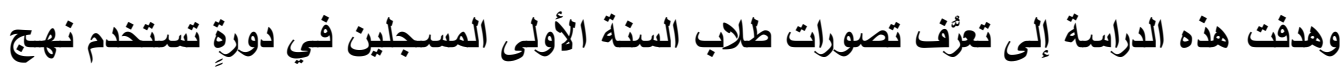

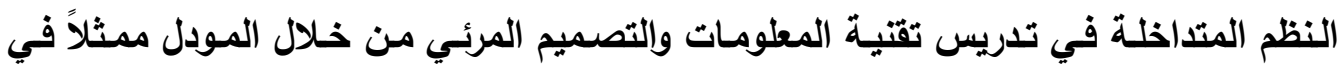

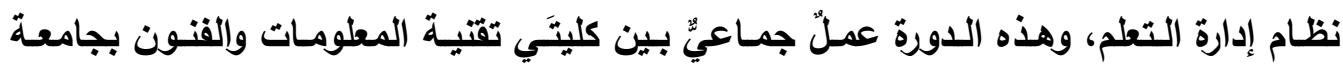
كوينزلاند للتقنية في أستراليا، أستخدم المنهج التجريبي، وتمثلت أداتها في استبانةٍ موجهةٍ

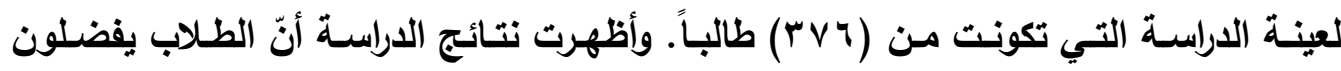

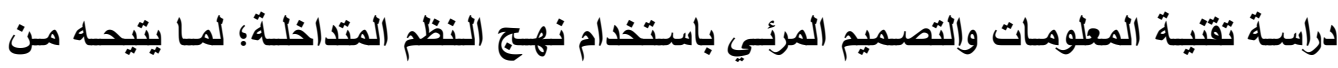
الإثراف الذاتي، والعمل التعاوني، ووجود مجموعةٍ متنوعةٍ من الطرق لزيادة مشاركة الطلاب في أنثطة التطلم. دراسلة ساجديك وديميركايا(Sagdic and Demirkaya, 2014) حيث أعدً الباحثنان دراسةً بعنوان: "تقويم نهج النظم المتداخلة في تدريس الجغرافيا"، وهدفت هذه الدراسة إلى تقويم نهج النظم المتداخلة في تدريس الجغرافيا في التعليم الثانوي

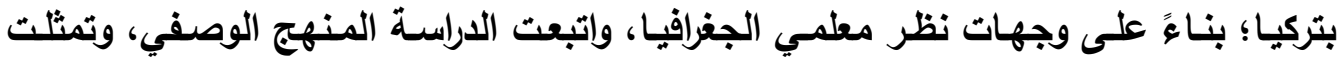

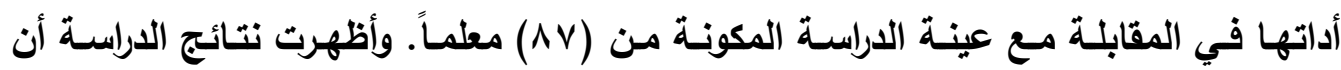
التدريس وفقاً لنهج النظم المتداخلة يناسب دروس الجغرافيا؛ حيث لاحظ معلمو الجغرافيا دوره الإيجابي في ترسيخ مفاهيم الموضوع الدراسي، وزيادة دافعية الطلاب نحو التعلم، وممارسة لإسنة التفكير، والقدرة على الاستتناج بسهولةِ.

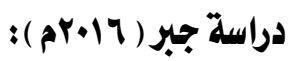
حيث أجرت الباحثة دراسةً بعنوان: "أثر توظيف نهج النظم المتداخلة في منهاج الفنون والحرف على التفكير الإبداعي والدافعية لدى طلبة الصف السيادس الأساسي في محافظة

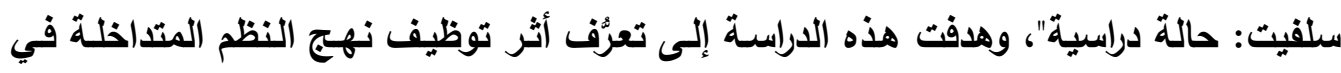

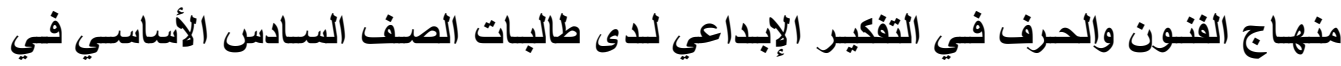
مدارس محافظة سلفيت في فلسطين، وفي دافعيتهن نحو تعلم هذا المنهاج، واتبعت الدراسة الإست

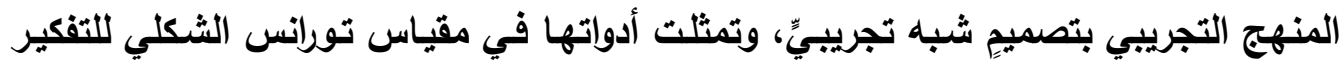

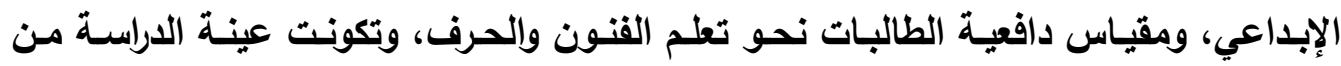




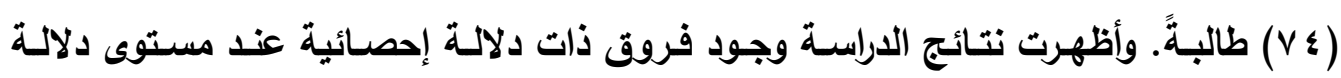

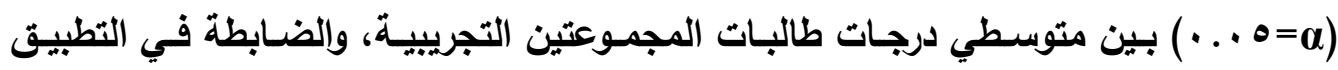

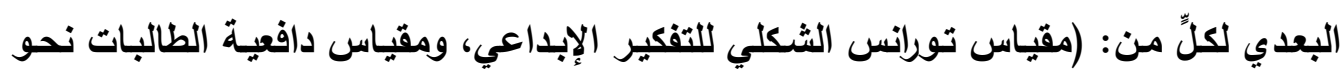
تعلم الفنون وإلحرف)، ولصالح المجموعة التجريبية.

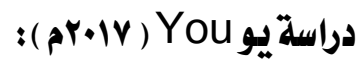

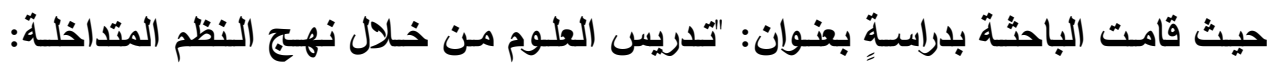

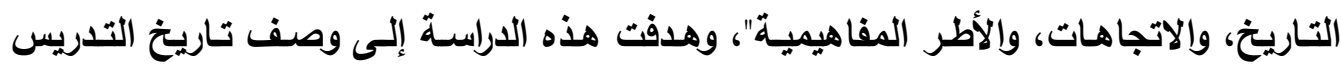

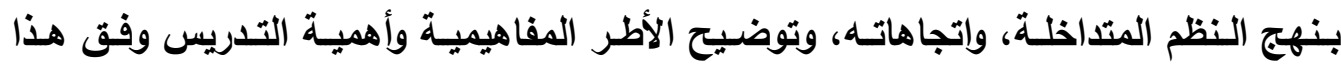

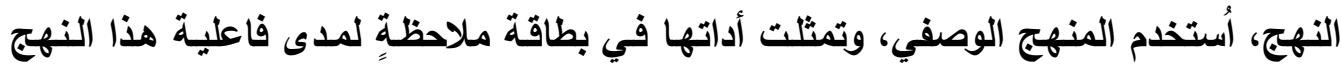

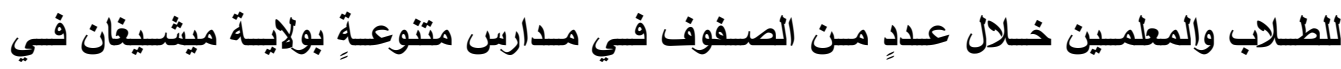

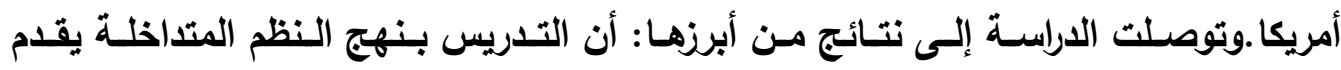

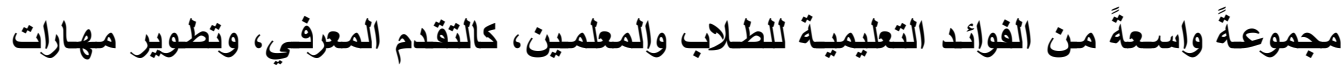
التفكير الناقد والاستدلالي وحل المشكلات، وتطوير جوهر المعرفة العام، وتعميق فهمها، ومن الفئن

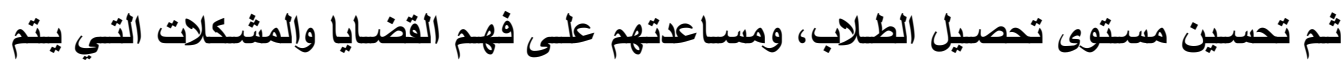
تقيمها في سياقاتٍ واقعيةٍ من الناحية العلمية، والتعامل معها باستخدام المعارف والمهارات ذات الصلة بتلك القضايا والمشكلات.

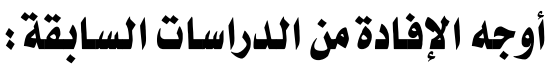

أفادت الدراسة الحالية من الدراسات السابقة في عدة جواتب، ومنها ما يأتي: - - توصيات ومقترحات الاراسات السابقة. - تعرُّ المنهجية البحثية، ويعض المراجع العلمية التي خدمت هذه الاراسة. - - إعداد أدوات هذه الدراسة. - - تحديد الأساليب الإحصائية المناسبة لهذه الدراسة. 


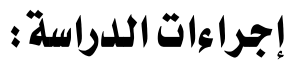

لتحقيق أهداف هذه الاراسة؛ تم اتبّاع الإجراءات الآتية:

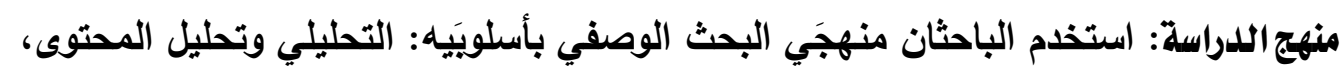
والتجريبي بتصميمٍ شبه تجريبيً. مجتمع الدراسة : تكوَّن مجتمع الاراسة من جميع تلاميذ الصف السادس الابتدائي في المدارس

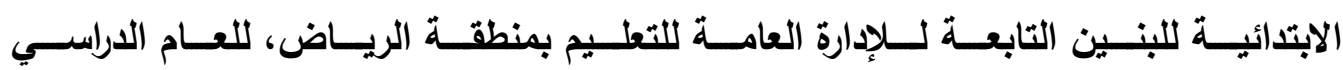

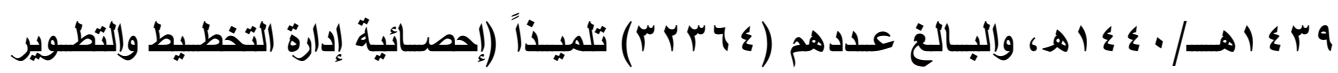

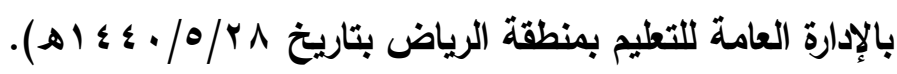

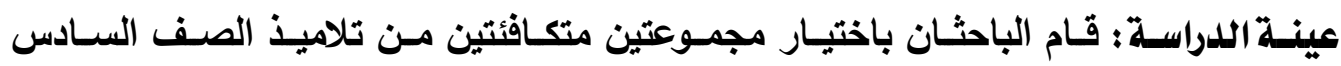
الابتدائي في مدينة الرياض؛ وذلك بالطريقة العشوائية العنقودية متعددة المراحل؛ وتم التعيين

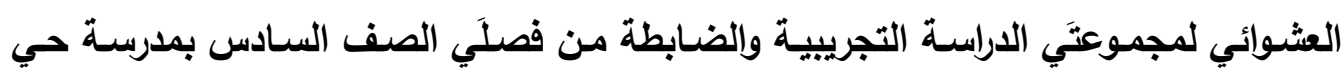

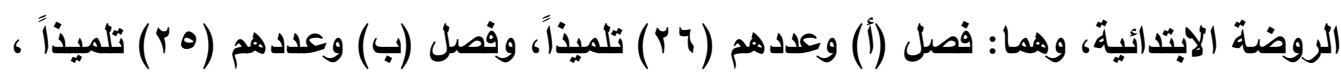

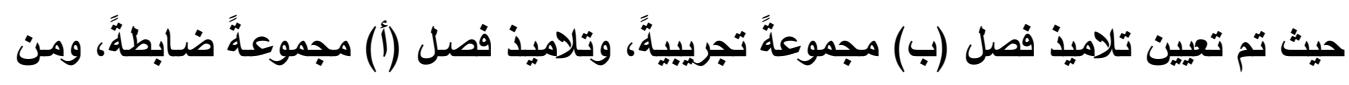

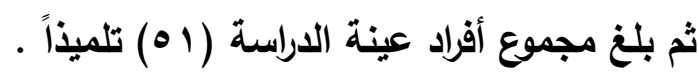

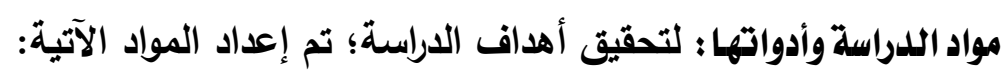
1) قُائمةٍ بالمفاهيم الثرعية في وحدة "الزكاة" من مقرر الفقه، المراد إكسابها لتلاميذ الصف التفال السادس الابتدائي.

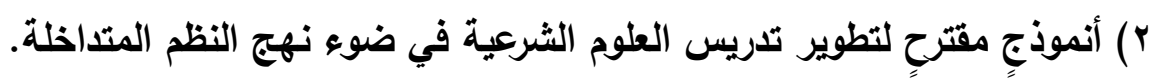

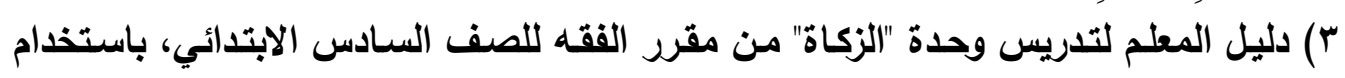
الأنموذج المقترح.

\section{كما تم إعداد الأداتين الآتيتين:}

1) اختبارٍ تحصيليً للمفـاهيم الثـرعية في وحدة "الزكاة" مـن مقرر الفقـه، المـراد إكسابها لتلاميذ الصف السادس الابتدائي. r ا اختبارٍ لقياس مهارات التفكير الاستدلالي في وحدة "الزكاة" من مقرر الفقه. 
إجراءات بناء مواد اللدراسة وأدواتها : تم بناء مواد اللدراسة وأدواتها على النحو الآتي: أولاً إعداد قائمة المفاهيم الشرعية: حيث تم إعداد هذه القائمة وفقاً للإجراءات الآتية: ( ) تحديد الهـف مـن إعداد قائمسة المفـاهيم الشـرعية: وذلك لتحديد تلك المفـاهيم، ومـن ثم إكسابها للتلاميذ من خلال تطوير تدريسها في ضوء نهج النظم المتداخلة، وقياس فاعلية ذللك في إكسابها.

r ) اختيار محتوى العلوم الثرعية: تم اختيار وحدة "الزكاة" من مقرر الفقه. r) تحليل المحتوى: وذلك بهذف تحديد المفاهيم الثرعية في محتوى وحدة "الزكاة"، حيث تم هذا من خلال الآتي: أ) الاطلاع على البحوث والدراسات السابقة التي تناولت أساليب تحليل المحتوى: وذلك للإفادة من منهجيتها المتبعة في التحليل. ب) تحديد الهدف من التحليل: وذلك لإعداد قائمةٍ محددةٍ للمفاهيم الثرعية في وحدة "الزكاة". ج) تحديد مجتمع التحليل: حيث تكوَّن من محتوى مقررات العلوم الثرعية للصف السـادس الابتدائي.

د) تحديد عينة التحليل: حيث تكوَّتت من محتوى وحدة "الزكاة" من مقرر الفقه.

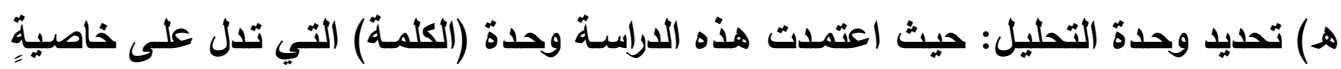
شرعيةٍ أو أكثر (المفهوم الشرعي). و) تصميم قائمة التحليل في صورتها الأولية: وذلك بهدف الوصف الموضوعي المنظم الكمي لما يتضمنه المحتوى من مفاهيم شرعية.

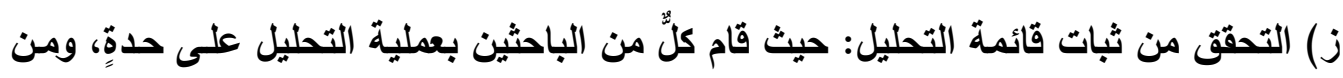

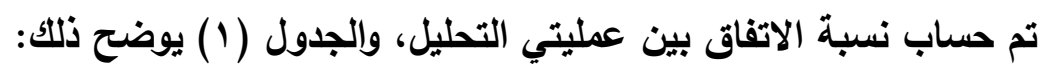
الجدول( (1): نسب الاتفاق بين عمليتي التحليل

\begin{tabular}{|c|c|c|c|}
\hline معامل الثبات & عدد نقاط الاتفاق & عدد المفاهيم & عملية التحليل \\
\hline \multirow{2}{*}{.91} & \multirow{2}{*}{0 . } & Or & الباحث الأول \\
\hline & & 0. & الباحث الثاني \\
\hline
\end{tabular}

ويوضح الجدول (1) أن معامل ثبات تحليل المحتوى وفقاً لمعادلة هولستي (Holisti)

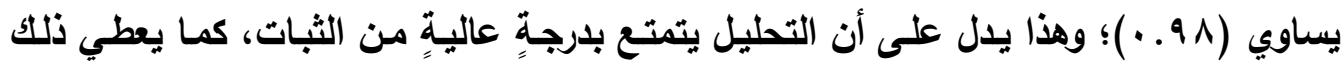
ثقةً في نتائج عمليتَي التحليل اللتين قام بهما الباحثان. 


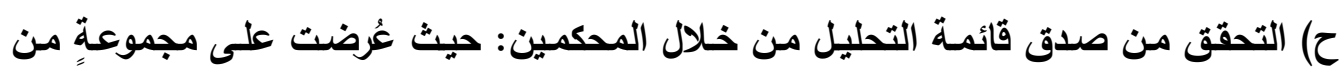

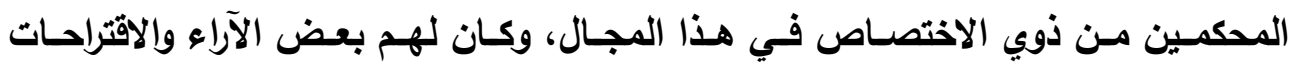

$$
\text { والملاحظات التي كانت محل اهتمام الباحثين. }
$$

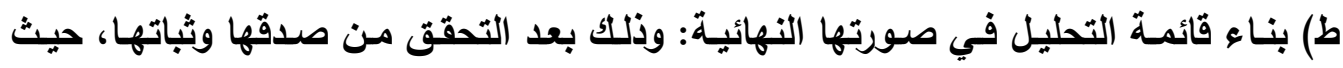

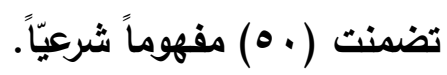

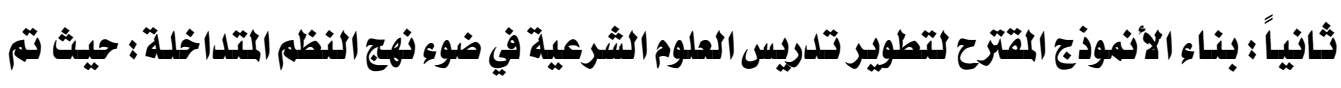

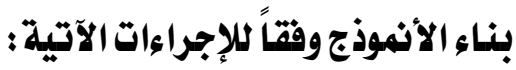
1) تحديد هدف الأنموذج المقترح: وذلك لتطوير تدريس العلوم الثرعية في ضوء نهج النظم

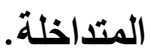
r) تحديد مصادر أسس الأنموذج المقترح ومبادئه في ضوء نهج النظم المتداخلة: وذلك من

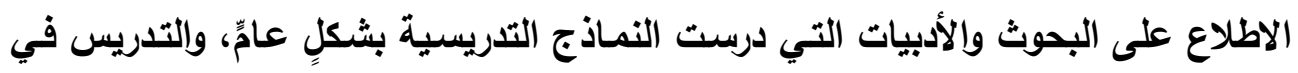

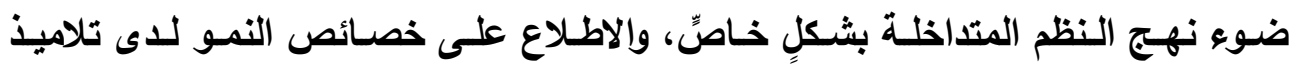
الصف السادس الابتدائي، إضافةً إلى آراء الخبراء والمختصين.

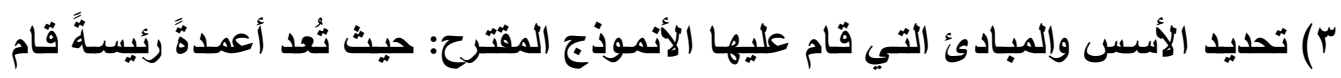
عليها الأنموذج المقترح. ؛ ) بناء وتصميم الأنموذج المقترح في صورته الأولية.

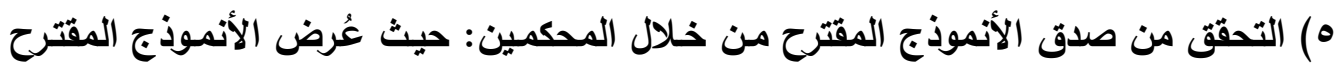

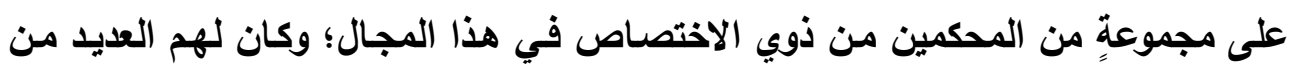
الآراء والاقتراحات والملاحظات التي أسهمت في تطوير هذا الأنموذج المقترح.

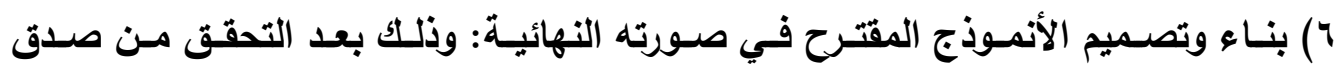
الأنموذج، حيث تضمن (؟) مراحل.

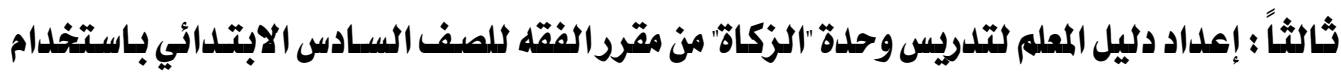
الأنموذج المقترح: حيث تم إعداد دليل المعلم وفقاً للإجراءات الآتية: ( ) تحديد هدف دليل المعلم: وذلكـ لمسـاعدة المعلم في تلريس وحدة "الزكـاة" باستخدام الأنموذج المقترح في ضوء نهج النظم المتاخلة. r) إعداد دليل المعلم في صورته الأولية. 


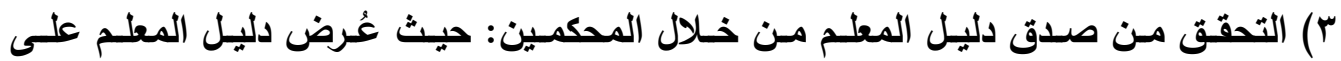
مجموعةٍ من المحكمين من ذوي الاختصاص في هذا المجال، وكان لهم العديد من الآراء والاقتراحات والملاحظات التي أسهمت في تطوير هذا الدليل. ع) إعداد دليل المعلم في صورته النهائية: وذلك بعد التحقق من صدقه.

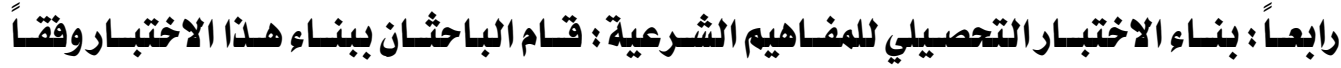
لإجراءات الآتية: 1) وضع اهداف اختبار المفاهيم الشرعية: وذلك للقياسين القبلي والبعدي لمستوى اكتسـاب المفاهيم الشرعية -في وحدة "الزكاة" من مقرر الفقه لتلاميذ الصف السـادس الابتدائيلاى المجموعتين التجريبية والضابطة في هذه الدراسة. ب) تحديد المستويات المعرفيـة للاختبار: حيث تبنت هذه الاراسـة تصنيف بلوم (Bloom) للأهداف المعرفيـة في إعداد اختبار المفاهيم الثـرعية، حيث شـمل الاختبار المستويات المعرفية الآتية: (التذكر، والفهم، والتطبيق، والتحليل، والتركيب، والتقويم). ب) بنـاء جدول المواصفات للاختبار: وذلك للتوصل إلى اختبارٍ متوازنٍ وعادلٍ يقيس عينةً ممثيةً للأهداف التعليمية والمحتوى التدريسي؛ حيث تم إيجاد الوزن النسبي للموضوعات وأسئلة الاختبار في المستويات المعرفية المتتوعة، ويذلك بلغت فقرات الاختبار ( • ع ) فقرةً. ع) بناء الاختبار في صورته الأولية. •) وضع تعليمات الاختبار. ؟) التحقق من صدق الاختبار من خلال المحكمين: حيث عُرض الاختبار على مجموعةٍ من المحكمين من ذوي الاختصساص في هذا المجال، وكان لهم العديد من الآراء والاقتراحات والملاحظات التي أسهمت في إخراج الاختبار بصورةٍ أفضل. V) التطبيق الاستطلاعي للاختبار: حيث تم تطبيق الاختبار على عينةٍ استطلاعيةٍ من مجتمع

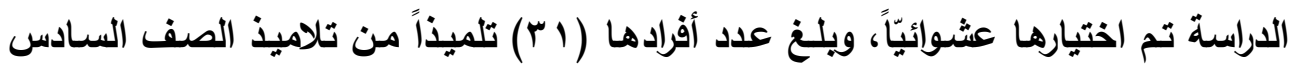
الابتدائي؛ وهدف هذا التطبيق إلىى تعرُّف وضـوح تعليمـات الاختبار، وأسـئلته، وحسـاب صدق الاتساق الداخلي للاختبار. 
ولتعرُّف مدى تحقق هذا النوع من الصدق في الاختبار؛ حُسب معاملات الارتباط بين

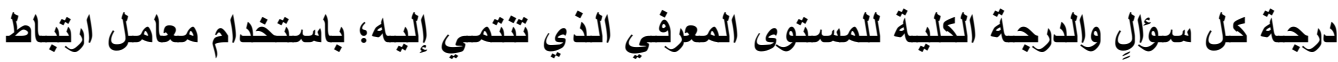

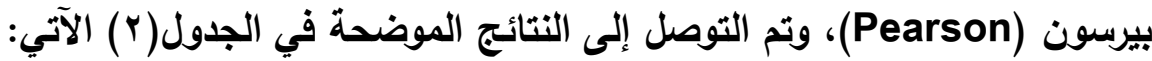

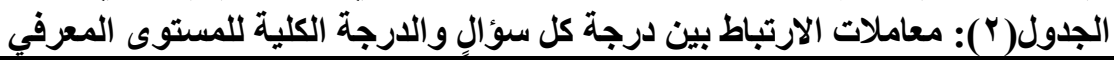

\begin{tabular}{|c|c|c|c|c|c|}
\hline معامل الارتباط & رقم السؤال & معامل الارتباط & رقم السؤال & معامل الارتباط & رقم السؤال \\
\hline$* * .7$. & pq & $* * \ldots \leqslant$ & 10 & $* * .79$ & 1 \\
\hline$* * . \vee V 4$ & $r$ & $* * .71$ & 17 & $* * . .7 \varepsilon$ & $r$ \\
\hline$* . . \leq \varepsilon$ & r & $* * .9 \varepsilon$ & IV & $* . . \leq 1$ & $\mu$ \\
\hline$* * .07$ & rr & $* * \ldots q 9$ & 11 & $* * . .7 \mu$ & $\varepsilon$ \\
\hline$* * . \Lambda Y$ & r & $* * .09$ & 19 & $* * . .0 \mathrm{~V}$ & 0 \\
\hline$* * . V 0$ & $r \varepsilon$ & $* * .09$ & $r \cdot$ & $* * .94$ & 7 \\
\hline$* *, \varepsilon \Lambda$ & ro & $* \cdot . \leqslant \mu$ & YI & $* * .71$ & V \\
\hline$* * . . \leqslant V$ & rq & $* * . \wedge 1$ & Yr & $* * .0 \leq$ & $\Lambda$ \\
\hline$* . \% \Lambda$ & $\mu v$ & $* *, \leqslant \Lambda$ & $r r$ & $* * . .7 \varepsilon$ & 9 \\
\hline$* * . . \leqslant \Lambda$ & $\mu$ & $* * .00$ & Y $\varepsilon$ & $* *, \wedge r$ & $1 \cdot$ \\
\hline$* . r q$ & rq & $* . . \leqslant \Lambda$ & ro & $* *, \mathrm{~V}$. & 11 \\
\hline$* *, . \leqslant V$ & $\varepsilon$ & $* * .01$ & ry & $* *, 07$ & Ir \\
\hline \multirow{2}{*}{\multicolumn{2}{|c|}{ 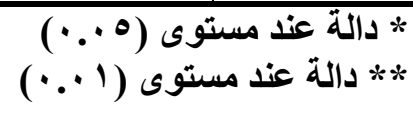 }} & $* . . \leqslant 7$ & rV & $* *, 0$. & Ir \\
\hline & & $* * . .0 \mathrm{~V}$ & r^ & $* *, 79$ & $1 \varepsilon$ \\
\hline
\end{tabular}

يوضح الجدول (Y) جميع قيم معاملات ارتباط أسئلة اختبار المفاهيم الثرعية بالدرجة

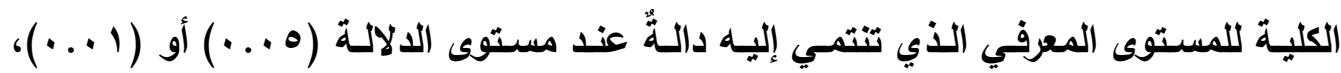

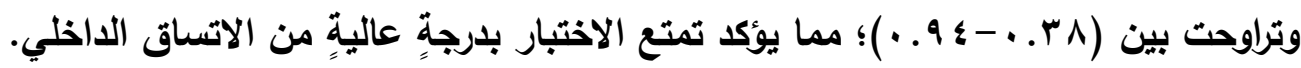
ج) حسـاب معامـل ثبـات الاختبـار : حيـ حُسب بطريقـة التجزئسة النصـفية (Spilt-Half) باستخدام معادلة سبيرمان - براون (Spearman-Brown)، وتم تقسيم الاختبار نظريّاً إلى

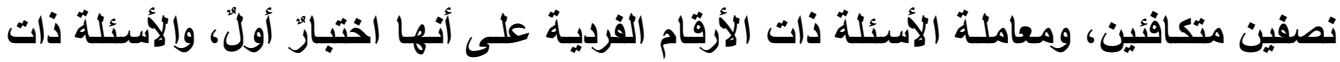
الأرقام الزوجية على أنها اختبارٌ ثُانِ، ثم صُححت الإجابـات، وحُسب معامـل الارتبـاط بين

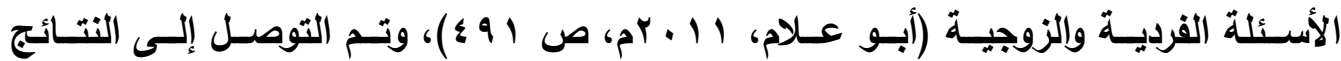
الموضحة في الجدول(ب) الآتي: 
أنموذج مقترح لتطوير تدريس العلوم الشرعية في ضوء نهج النظم المتداخلة ....

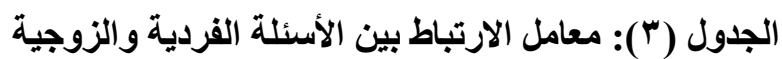

\begin{tabular}{|c|c|c|}
\hline معامل الثبات & معامل الارتباط & المستوى المعرفي للاختبار \\
\hline$\cdot \wedge \varepsilon$ & $\cdot V Y$ & التذكر \\
\hline. .17 &. $.7 r$ & الفهم - م الفم \\
\hline$\because V V$ & $.9 \pi$ & التطبيق \\
\hline$. V \leq$ & .09 & التحليل \\
\hline.$\wedge \theta$ & $. V \leq$ & التركيب \\
\hline.$\wedge 1$ &. .71 & التقويم \\
\hline $.9 \varepsilon$ &..$\wedge 9$ & كل المستويات المعرفية للاختبار \\
\hline
\end{tabular}

يوضح الجدول (r) اختبار المفاهيم الثرعية يتمتع بدرجةٍ عاليةٍ من الثبات، وصالحِّ

للتطبيق؛ حيث بلغ معامل الثبات الكلي للاختبار باستخدام معادلة سبيرمان - براون ( 9 ـ . )). د) حسـاب معاملات السـهولة والصعوية لأسئلة الاختبار : حيث حُسب معامل السـهولة لكل

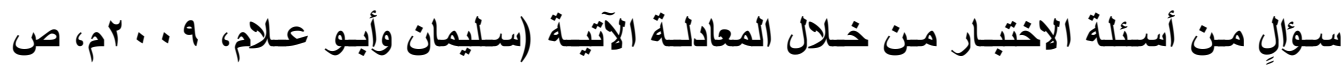
ب بن $:(r) r$ ؛ حيث مج ص: مجموع الإجابات الصحيحة،

$$
\text { بج }
$$$$
\text { معامل السهولة = }
$$

ومج خ: مجموع الإجابات الخاطئة.

ويُقصد بمعامل الصعوية: "تسبة الطلاب الذين لـم يجيبوا عن السوأل إلى العدد الكلي

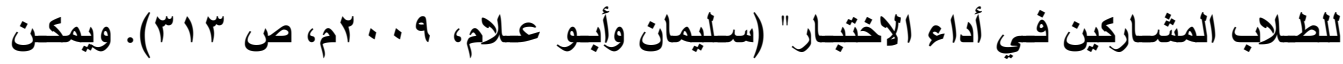
حساب معامل الصعوية لكل سؤالٍ من أسئلة الاختبار من خلال المعادلة الآتية:

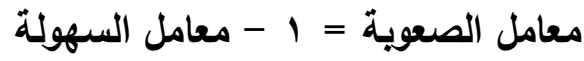


أنموذج مقترح لتطوير تدريس العلوم الشرعية في ضوء نهج النظم المتداخحلة ...

والجدول (ع) يوضح معاملات السهولة والصعوبة لأسئلة اختبار المفاهيم الثرعية:

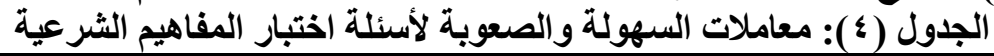

\begin{tabular}{|c|c|c|c|c|c|}
\hline معامل الصعوبة & معامل السهولة & b & معامل الصعوبة & معامل السهولة & م \\
\hline. .81 &..$r q$ & & $.0 r$ & 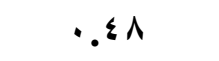 & \\
\hline..$r q$ &. .81 & & .70 & ס ט. & \\
\hline $.0 \wedge$ &..$\varepsilon r$ & & .00 &..$\leqslant 0$ & \\
\hline. .71 & • & &. .81 &.$r q$ & \\
\hline.$V V$ & 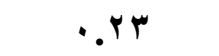 & &.$V \varepsilon$ &.$Y T$ & \\
\hline $.0 r$ & $\cdot . \leqslant \Lambda$ & &. .71 &.$r q$ & \\
\hline .00 & .00 & &..$V \varepsilon$ &.$Y T$ & \\
\hline. .71 & •.r & &..$V V$ & rr. & \\
\hline .00 &..$\leqslant 0$ & & .70 & ט. & \\
\hline.$\varphi q$ &. .71 & &. .70 & ס ט. & \\
\hline. .71 & • & &.$M^{M r}$ &. .71 & \\
\hline. .71 & . & & .00 &..$\leqslant 0$ & \\
\hline. .70 & • & & .00 &..$\leqslant 0$ & \\
\hline.$V \varepsilon$ & I & &. .81 &.$r q$ & \\
\hline.$V \varepsilon$ & . Y & &. .71 &..$r q$ & \\
\hline. .81 & . rq & &.$V V$ &.$r r$ & \\
\hline. .71 & • & &., 00 &..$\leqslant 0$ & \\
\hline$\cdot 71$ & r r & & $\cdot, V \varepsilon$ &..$Y q$ & \\
\hline. .70 & ه ب. & &. .71 & r r & \\
\hline. .81 &..$r q$ & &. .71 &..$r q$ & \\
\hline
\end{tabular}

يوضـح الجـدول(؛ ) معـاملات السـهولة والصـوية لأسـئلة اختبـار المفـاهيم الشـرعية

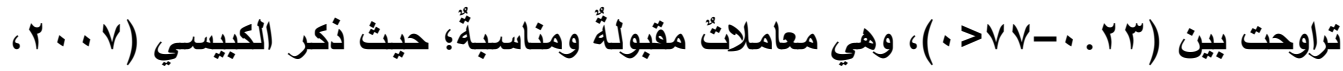


أنموذج مقترح لنطوير تدريس العلوم الشرعية في ضوء نهج النظم المتداخلة .

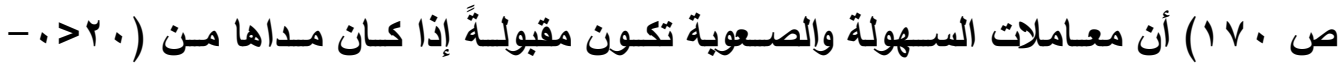
$\cdot(\cdot>\Lambda$.

هـ) حساب معاملات التمييز لأسئلة الاختبار : ويسـاعد معامل التمييز في تحديد قدرة السؤال على التمييز بين الطلاب ذوي التحصيل المتـني والطـلاب ذوي التحصيل العـالي (النبهان،

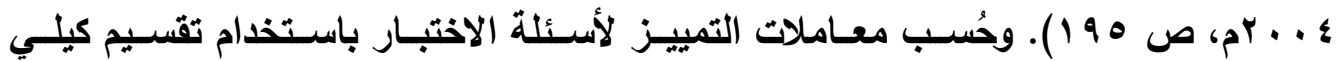
(الذي يعتمد على الخطوات الآتية (زيتون، ب... (Kelly) • ترتيب أوراق التلاميذ حسب الارجات. • فصل (rv \% من درجات أفراد العينة التي تقع في الجزء العلوي. • فصل (rv \% من درجات أفراد العينة التي تقع في الجزيء السفلي. • استخدام معادلة جونسون (Johnson):

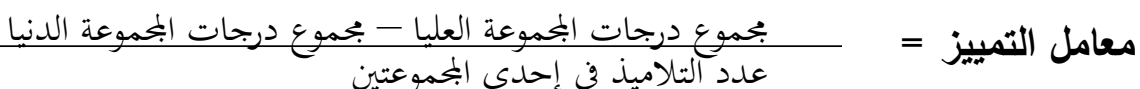

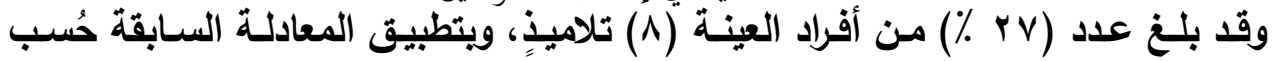
معامل تمييز كل سؤالٍ من أسئلة الاختبار، وتم التوصل إلى النتائج الموضحة في الجدول الجدول (0): معامل تمييز كل سؤالٍ من أسئلة الاختبار

\begin{tabular}{|c|c|c|c|c|c|c|c|}
\hline معامل التمييز & م & معامل التمييز & م & معامل التمييز & م & معامل التمييز & م \\
\hline.$\mu \Lambda$ & &. ro & & .0 & &.$\wedge \Lambda$ & \\
\hline. .74 & & .0 & &.$Y 0$ & &..$Y 0$ & \\
\hline..$\vee 0$ & &.$r \theta$ & &..$\mu$ & &..$\mu$ & \\
\hline. .74 & &. .74 & & . rᄉ & &.$Y 0$ & \\
\hline$\cdot / \mu \wedge$ & &.$r \Delta$ & &.$r \theta$ & &..$\mu$ & \\
\hline .0 & & .0 & & .0 & &.$\wedge \wedge$ & \\
\hline.$Y 0$ & & .0 & &..$\mu \Lambda$ & &..$\mu$ & \\
\hline .0 & &.$r^{\prime}$ & & .0 & &..$\mu$ & \\
\hline.$r^{\prime}$ & & $\because 0$ & & 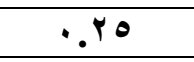 & & $\because V 0$ & \\
\hline. .90 & &. .74 & & .0 & & .0 & \\
\hline
\end{tabular}

يوضح الجدول (0) أن معاملات التمييز لأسئلة اختبار المفاهيم الشرعية تراوحت بين

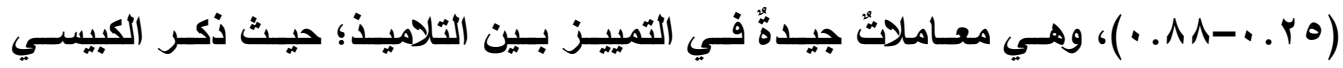

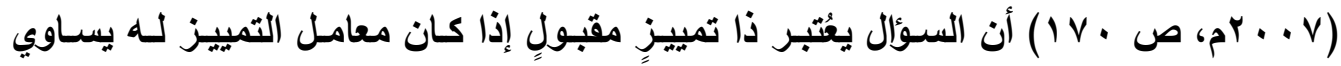
( • بز • ) فأعلى، وكلما زاد معامل التمييز كان ذلك أفضل. 
و) حساب زمن الاختبار: حُسب زمن الاختبار من خلال حساب متوسط الزمن الذي استغرقه جميع التلاميذ للإجابة عن أسئلة الاختبار؛ وذلك وفقاً للمعادلة الآتية:

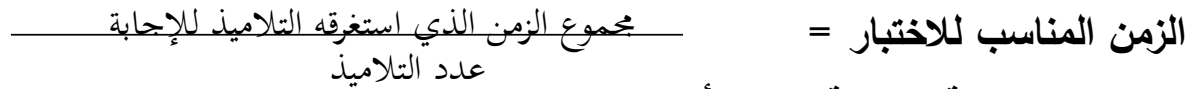

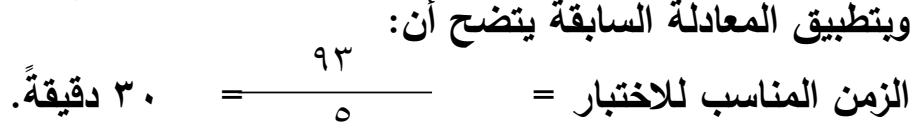

^) إخراج اختبار المفـاهيم الشرعية في صورته النهائية: حيث تكوَّن الاختبار في صورته النهائية من ( • ع ) سوألاً. خامساً ؛ بناء اختبار مهارات التفكير الاستدلالي: التوال تم بناء اختبار مهارات التفكير الاستدلالي وفقاً للإجراءات الآتية: ( ) تحديد الهدف مس اختبار مهارات التفكير الاستـلالي: وذلك للقياسين القبلي والبعدي

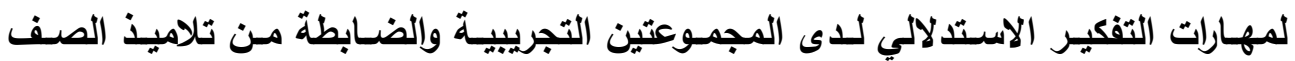
السادس الابتدائي في وحدة "الزكاة" من مقرر الفقه.

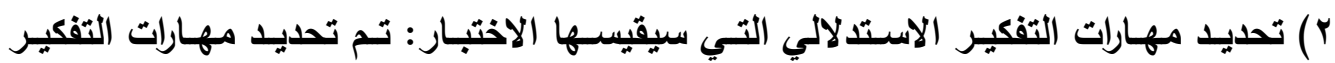
الاستـلالي مـن خـلال الاطـلاع على الأدبيـات والدراسـات التربويـة والمراجـع التـي تناولت التفكير الاستدلالي على النحو الآتي: (الاستنباط، والاستقراء، والاستنتاج).

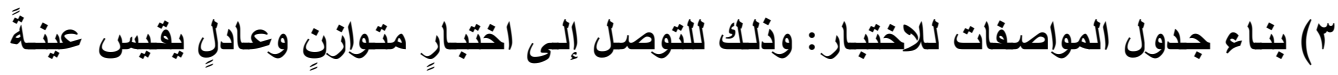

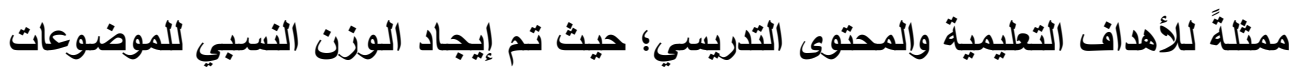

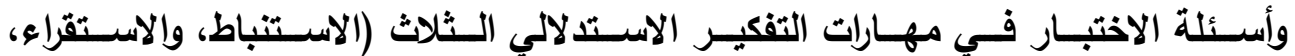
والاستنتاج)، ويذلك بلغت فقرات الاختبار (VY) فقرةً. ؛ ) بناء الاختبار في صورته الأولية. •) وضع تعليمات الاختبار. ז) التحقق من صدق الاختبار من خلال المحكمين: حيث عُرض الاختبار على مجموعةٍ من المحكمين من ذوي الاختصاص في هذا المجال، وكان لهم العليد من الآراء والاقتراحات والملاحظات التي أسهمت في إخراج الاختبار بصورةٍ أفضل. 
أنموذج مقترح لنطوير تدريس العلوم الشرعية في ضوء نهج النظم المتداخلة .

V التطبيق الاستطلاعي للاختبار:حيث تم تطبيق الاختبار على عينةٍ استطلاعيةٍ من مجتمع

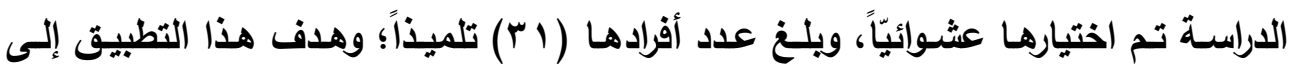

\section{تعرُّف ما بأتي:}

أ) وضوح تعليمات الاختبار، وأسئلته. ب) حسـاب صدق الاتسـاق الداخلي للاختبار : حيث حُسب معاملات الارتبـاط بين درجـة كل سؤالٍ والدرجة الكلية لمهارة التفكير الاستدلالي التي ينتمي إليها؛ باستخدام معامل ارتباط بيرسون (Pearson)، وتم التوصل إلى النتائج الموضحة في الجدول (†) الآتي:

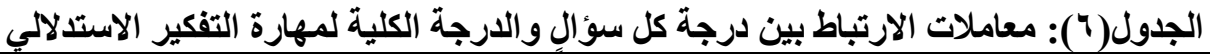

\begin{tabular}{|c|c|c|c|c|c|}
\hline معامل الارتباط & رقم العبارة & معامل الارثباط & رقم العبارة & معامل الارتباط & رقمث \\
\hline$* . . \leqslant 1$ & $\varepsilon 9$ & $*, \ldots \varepsilon$ & ro & $* * \bullet \bullet \wedge$ & 1 \\
\hline$* *, . \leqslant \Lambda$ & 0 . & $* * .77$ & rq & $* * . .7 \mu$ & $r$ \\
\hline$* *, 01$ & 01 & $* * . .7 r$ & YV & $* *, . \vee \wedge$ & $\mu$ \\
\hline$* *, \leq 1$ & $\Delta Y$ & $* * . .7 Y$ & $r \Lambda$ & $* * . .7 V$ & $\varepsilon$ \\
\hline$* * 01$ & or & $* * .0 \mu$ & pq & $* * . V \psi$ & 0 \\
\hline$* *, \leq \vee V$ & $0 \varepsilon$ & $* *, 00$ & $\mu$ & $* * .09$ & 7 \\
\hline$* . \varepsilon$. & 00 & $* * . .7 Y$ & r & $* *, \ldots q$ & V \\
\hline$* * \bullet .00$ & 07 & $* * . \leq 7$ & $r r$ & $* . \leqslant 0$ & $\Lambda$ \\
\hline$* . \_\psi$ & $\Delta V$ & $* * \ldots q 9$ & r & $* * . \leqslant 7$ & 9 \\
\hline$* * \leq \leqslant 9$ & $\Delta \wedge$ & $* . \leq \varepsilon$ & $\mu \varepsilon$ & $* * \bullet \Delta \mu$ & 1. \\
\hline$* . \leqslant 0$ & 09 & $* \varepsilon$. & ه & $* \varepsilon Y$ & 11 \\
\hline$* . \leqslant Y$ & 7. & $* . . \% q$ & r & $* . \mu \Lambda$ & $1 Y$ \\
\hline$* * .09$ & 71 & $* . \varepsilon Y$ & $\mu v$ & $* * \Delta, \Delta \mu$ & $1 \%$ \\
\hline$* . \leq \varepsilon$ & $7 r$ & $* . . \mu V$ & $\mu \Lambda$ & $* . \leqslant 0$ & $1 \varepsilon$ \\
\hline$* *, 0$ & 7 & $*, \varepsilon \varepsilon$ & rq & 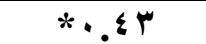 & 10 \\
\hline$* * \bullet \bullet V$ & $7 \varepsilon$ & $* * .0 \mu$ & $\varepsilon$. & $* * . . V V$ & 17 \\
\hline$* *, . \leqslant 7$ & 70 & $* *, \leq 4$ & $\varepsilon 1$ & $* * \bullet \bullet \wedge$ & $1 V$ \\
\hline$* * .09$ & 77 & $* *, \varepsilon 7$ & $\varepsilon Y$ & $* *, V \psi$ & 11 \\
\hline$* *, . \leqslant 7$ & $7 V$ & $* . \varepsilon Y$ & $\varepsilon \mu$ & $* *, \leq \Lambda$ & 19 \\
\hline$* . \varepsilon$ & 71 & $* . \varepsilon$. & $\varepsilon \varepsilon$ & $* * . .7 Y$ & Y. \\
\hline$* * . .7 \mu$ & 79 & $* . . \% q$ & $\varepsilon 0$ & $* * .09$ & YI \\
\hline$* * \bullet \bullet r$ & $V$. & $* . \mu \Lambda$ & $\varepsilon 7$ & $* * . \vee V$ & $r r$ \\
\hline$* . \mu \Lambda$ & VI & $*$ * q & $\varepsilon V$ & $* * \Delta, 0 \mu$ & $r$ \\
\hline$* *, . \leqslant 1$ & VY & $* . \varepsilon$ & $\varepsilon \Lambda$ & $* *$ & Y $\varepsilon$ \\
\hline
\end{tabular}


أنموذج مقترح لتطوير تدريس العلوم الشرعية في ضوء نهج النظم المتداخلة ....

يوضتح الجدول (7) أن جميع قيم معاملات ارتباط أسئلة الاختبار بالارجة الكلية لمهارة

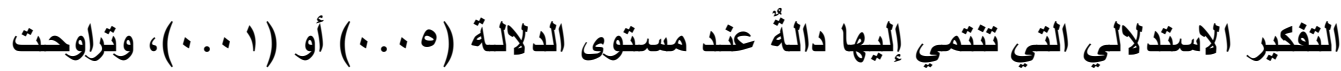

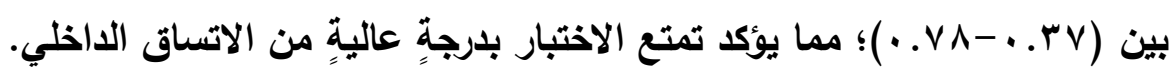

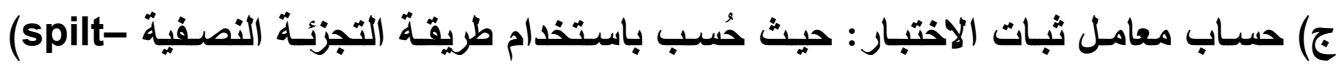

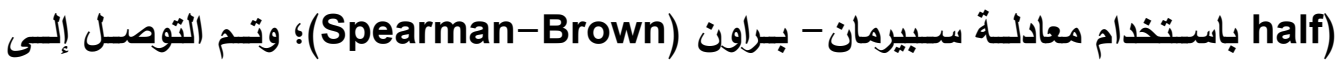
النتائج الموضحة في الجدول(V) الآتي:

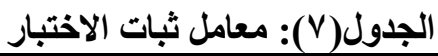

\begin{tabular}{|c|c|c|}
\hline معامل الثبات & معامل الارتباط & مهارة التفكير الاستدلالي \\
\hline .91 & .90 & مهارة الاستتباط \\
\hline .94 &.$\wedge 0$ & مهارة الاستقراء \\
\hline.$\wedge 0$ &.$V \varepsilon$ & مهارة الاستنتاج \\
\hline. .91 &. .97 & كل مهارات التفكير الاستدلالي في الاختبار \\
\hline
\end{tabular}

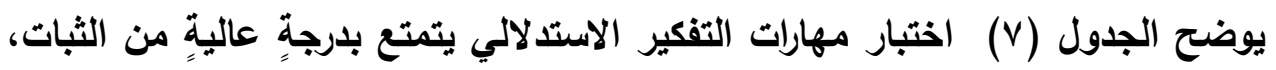

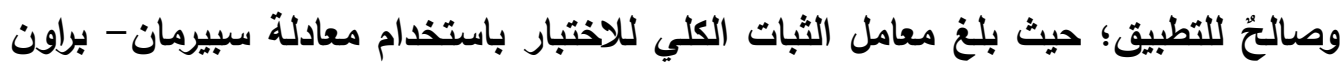
.$(\cdot 9 \Lambda)$ د) حسـاب معساملات السـهولة والصـعوية لأسـئلة الاختبـار : حيـث حُسـب معـاملَي السـهولة

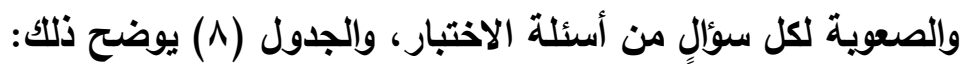

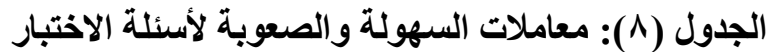

\begin{tabular}{|c|c|c|c|c|c|}
\hline معامل الصعوبة & معامل السهولة & b & معامل الصعوبة & معامل السهولة & م \\
\hline.$V \varepsilon$ & 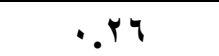 & $r v$ &. .71 &..$\mu q$ & 1 \\
\hline. Ho & .70 & $\mu \wedge$ & .01 & $\because \varepsilon Y$ & $r$ \\
\hline $.0 r$ &..$\leqslant \Lambda$ & rq & $.0 r$ &..$\leqslant \Lambda$ & $r$ \\
\hline. .91 & $.0 q$ & $\varepsilon$. &. .71 &.$M r$ & $\varepsilon$ \\
\hline .70 & ه & $\& 1$ & .00 & $\because \leq 0$ & 0 \\
\hline. .70 & ט & $\varepsilon Y$ & .91 &..$M r$ & 9 \\
\hline. .71 & $\cdot r q$ & $\varepsilon r$ & $\because \diamond \wedge$ & $\because \varepsilon Y$ & $V$ \\
\hline $.0 \wedge$ &.$\varepsilon Y$ & $\varepsilon \varepsilon$ & $.0 \wedge$ & 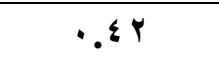 & $\Lambda$ \\
\hline $.0 Y$ & $\because \varepsilon \Lambda$ & $\varepsilon 0$ & .01 &..$\leqslant Y$ & 9 \\
\hline .70 & هץ. & $\leqslant 7$ & .00 & $\because \leqslant 0$ & 1. \\
\hline .00 & $\because \leqslant 0$ & $\varepsilon V$ &. .71 & 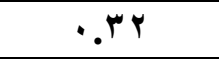 & 11 \\
\hline $.0 Y$ &..$\leqslant \Lambda$ & $\varepsilon \wedge$ &.$V \varepsilon$ & YY." & Ir \\
\hline ד & $. . V \leq$ & $\& 9$ & .00 & $\because \leqslant 0$ & 14 \\
\hline
\end{tabular}


أنموذج مقترح لتطوير تدريس العلوم الشرعية في ضوء نهج النظم المتداخلة ....

\begin{tabular}{|c|c|c|c|c|c|}
\hline معامل الصعوبة & معامل السهولة & 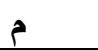 & معامل الصعوبة & معامل السهولة & 5 \\
\hline. .71 & . rr & 0 . &. .70 & • ט & 18 \\
\hline 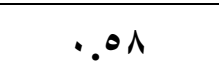 & $\cdot . \varepsilon r$ & 01 &. .11 &.$r q$ & 10 \\
\hline$\because O r$ & $\cdot . \leqslant \Lambda$ & Or &. .71 & q & 17 \\
\hline. .71 &.$r q$ & Or & $.0 \wedge$ & $\cdot . \varepsilon r$ & 18 \\
\hline •rr & .71 & $0\}$ & .00 & $\because \leqslant 0$ & 11 \\
\hline .00 & $\because \leqslant 0$ & 00 & .00 &.$\leqslant 0$ & 19 \\
\hline . rq & 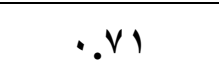 & 07 & .70 & ט & $r \cdot$ \\
\hline . &. .71 & $\Delta V$ & $.0 \wedge$ &..$\varepsilon r$ & YI \\
\hline. .71 & $\cdot . r q$ & $\Delta \Lambda$ & .00 &..$\leqslant 0$ & rr \\
\hline .70 & • & 09 & .01 & $\cdot . \leqslant r$ & $r r$ \\
\hline. .71 & . & 7. &. .71 & q & $r \varepsilon$ \\
\hline..$V V$ & • & 71 &. .71 &..$r q$ & ro \\
\hline$\because V \varepsilon$ & 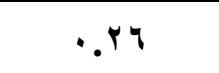 & $7 r$ &. .71 & $\cdot . r q$ & YY \\
\hline .00 & $\because \leqslant 0$ & $4 r$ & $.0 r$ & $\because . \leqslant \Lambda$ & $r V$ \\
\hline .00 & $\because \leqslant 0$ & $7 \varepsilon$ & $.0 r$ & $\cdot . \leqslant \wedge$ & $r \Lambda$ \\
\hline.$V_{1}$ & - rq & 70 & .71 & $\cdot . r r$ & rq \\
\hline.$v 1$ & - rq & 79 & .00 &.$\leqslant 0$ & $r$ \\
\hline. .81 &.$r q$ & $7 V$ &. .71 & . & M \\
\hline .00 &..$\leqslant 0$ & 71 & $.0 \wedge$ & $\cdot \varepsilon r$ & rr \\
\hline .70 & ט & 79 & $\because \Delta \wedge$ & $\cdot . \varepsilon r$ & r \\
\hline $.0 \wedge$ & $\because \varepsilon r$ & $V \cdot$ & $.0 \wedge$ & $\cdot . \varepsilon r$ & ME \\
\hline..$v V$ & & VI & .00 &..$\leqslant 0$ & ro \\
\hline. .71 & . & $V Y$ &. .71 & r r & rq \\
\hline
\end{tabular}


أنموذج مقترح لتطوير تدريس العلوم الشرعية في ضوء نهج النظم المتداخلة ....

يوضـح الجـدول (^) معـاملات السـهولة والصـعوية لأســلة اختبـار مهـارات التفكيـر

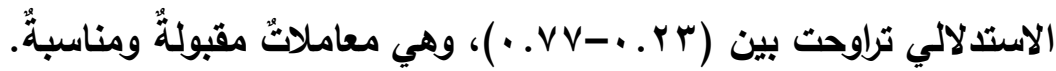
ه) حساب معاملات التمييز لأسئلة الاختبار: حيث حُسب معاملات التمييز لأسئلة الاختبار، والتوصل إلى النتائج الموضحة في الجدول(9) الآتي: الجدول (9): معاملات التمييز لأسئلة الاختبار

\begin{tabular}{|c|c|c|c|c|c|}
\hline معامل التمييز & م & معامل التمييز & b & معامل التمييز & 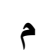 \\
\hline .0 & $\varepsilon 9$ & 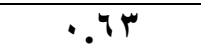 & ro &. $.7 \mu$ & 1 \\
\hline.$Y 0$ & 0. &..$\wedge \Lambda$ & $r q$ &. .80 & r \\
\hline .97 & 01 &..$\wedge \wedge$ & $r V$ &.$\wedge \wedge$ & $r$ \\
\hline.$\mu \Lambda$ & Or &.$\wedge \wedge$ & $r \Lambda$ &.$\vee 0$ & $\varepsilon$ \\
\hline .97 & or &. $\mathrm{Vo}$ & rq &. $\mathrm{Vo}$ & 0 \\
\hline .0 & O\& &.$V 0$ & $r$ &..$V 0$ & 7 \\
\hline .0 & 00 &.$V 0$ & $\mu_{1}$ & .94 & V \\
\hline.$r 0$ & 09 &. .74 & $r r$ &..$V 0$ & $\Lambda$ \\
\hline.$Y 0$ & ov & $\because V 0$ & $r$ & .97 & 9 \\
\hline. .74 & $0 \wedge$ & .97 & $r \varepsilon$ & .94 & 1. \\
\hline..$\mu \Lambda$ & 09 & .97 & ro &.$\mu \wedge$ & 11 \\
\hline..$\mu \Lambda$ & 7. &.$\mu \Lambda$ & $r q$ & .0 & IT \\
\hline.$V 0$ & 71 & .0 & $\mu v$ &. .74 & Ir \\
\hline. YO & $9 Y$ &. Yo & $r \Lambda$ &..$\mu \Lambda$ & $1 \leq$ \\
\hline. .74 & Tr &.$\mu \Lambda$ & $r q$ & .0 & 10 \\
\hline.$V 0$ & $7 \varepsilon$ & .0 & $\varepsilon$. &.$\wedge \wedge$ & 17 \\
\hline..$Y 0$ & 70 &..$\mu \Lambda$ & $\& 1$ &. .74 & 18 \\
\hline .97 & 79 &.$\mu \Lambda$ & $\varepsilon Y$ & .100 & 11 \\
\hline. Yo & $7 V$ &. Yo & $\varepsilon \psi$ & $\because 0$ & 19 \\
\hline..$r o$ & 71 & $\cdot, \mu \wedge$ & $\varepsilon \varepsilon$ &. $\mathrm{VO}$ & $r$. \\
\hline.$V 0$ & 79 & .0 & $\leqslant 0$ & .94 & YI \\
\hline. .10 & $V$. & .0 & $\leqslant 7$ &.$\vee v 0$ & $r Y$ \\
\hline. YO & VI & .0 & $\varepsilon V$ & r & $r r$ \\
\hline. ro & $V Y$ &.$\mu \Lambda$ & $\varepsilon \Lambda$ & .74 & $r \varepsilon$ \\
\hline
\end{tabular}

يوضح الجدول (9) معاملاث التمييز لأسئلة اختبار مهاراث التفكير الاستدلالي تراوحث

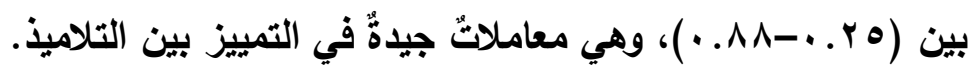

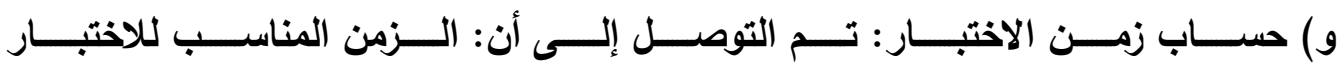
س س دقيقةً $=$ 
أنموذج مقترح لتطوير تدريس العلوم الشرعية في ضوء نهج النظم المتداخلة ....

9) إخراج اختبار مهارات التفكير الاستدلالي في صورته النهائية: حيث تكوَّن الاختبار في صورته النهائية من (VY) فقرةً.

إجراءات تطبيق الدراسة :

بعد الانتهاء من إعداد مواد الدراسـة وأدواتها بصورتها النهائية؛ قام الباحثان بإجراءات تطبيق الاراسة التي تضمنت ما يأتي: ( ) الحصول على خطاباتٍ رسميةٍ لتسهيل مهام الباحثين.

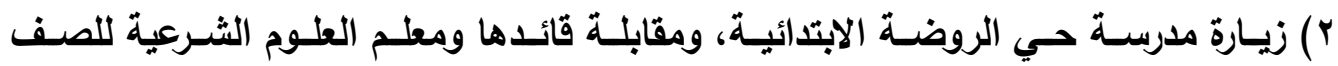

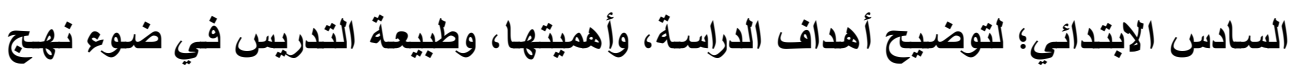
النظم المتداخلة، وإجراءات تنفيذه وفقاً للأنموذج المقترح، وتم الاتفاق على أن يتولى أحد الباحثين مهمة تدريس مجموعتَي الاراسة.

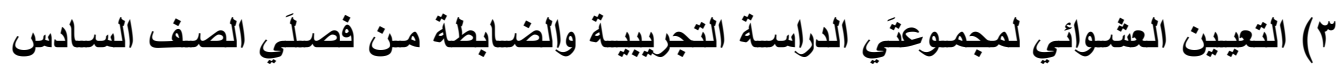

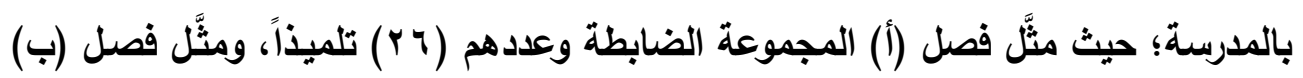

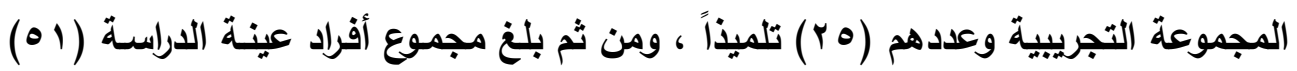
تلميذاً. ؛) قام الباحثنان بضسط المتغيرات غير التجريبية التي يمكن أن تـؤثر في نتائج الدراسـة؛

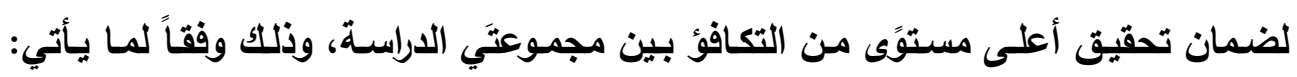
العمر الزمني، والخبرة السـابقة للتلاميذ، وعدد الحصص، كمـا تم التطبيق القبلي لاختبار

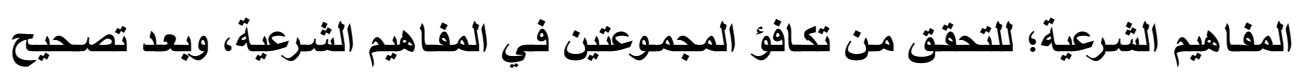

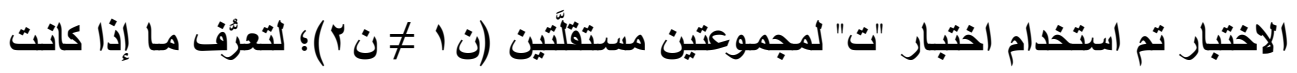

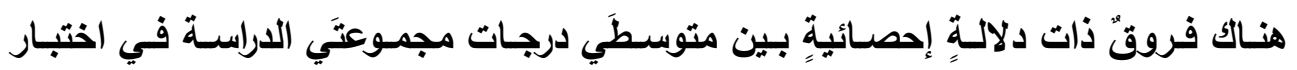

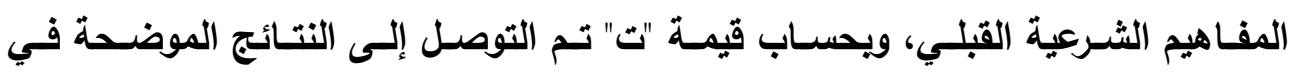

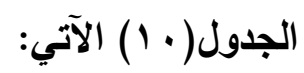


أنموذج مقترح لتطوير تدريس العلوم الشرعية في ضوء نهج النظم المتداخلة ....

الجدول ( • 1): متوسطَ درجات مجموعتَي الاراسة في اختبار المفاهيم الشرعية القبلي

\begin{tabular}{|c|c|c|c|c|c|c|c|c|}
\hline مستوى الدلاكة & 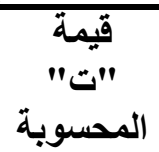 & 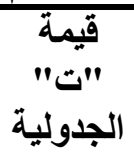 & الحرجية & الالمعراف & الحستوسطي & العدد & المجموعة & المستوفي \\
\hline \multirow{2}{*}{.91} & \multirow{2}{*}{.$O r$} & \multirow{8}{*}{$r, r$} & \multirow{8}{*}{$\varepsilon 9$} & $1 \ldots$ & $r . .1$ & ro & التجريبية & \multirow{2}{*}{ التذكر } \\
\hline & & & & 1.08 & r.YV & $r q$ & الضابطة & \\
\hline \multirow{2}{*}{.$\wedge V$} & \multirow{2}{*}{.017} & & & $1 \ldots$ & $r . \varepsilon \varepsilon$ & ro & التجريبية & \multirow{2}{*}{ الفهم } \\
\hline & & & & 1.47 & ג."r & $r y$ & الضابطة & \\
\hline \multirow[b]{2}{*}{.$\leqslant 9$} & \multirow[b]{2}{*}{. .79} & & &..$\wedge 9$ & 1.8 & ro & التجريبية & \multirow[b]{2}{*}{ التطبيق } \\
\hline & & & & $1 . v$ & Mr & Y & الضابطة & \\
\hline \multirow{2}{*}{.$\vee 19$} & \multirow{2}{*}{ TY } & & & $1 . Y \varepsilon$ & $r . V r$ & ro & التجريبية & \multirow{2}{*}{ التحليل } \\
\hline & & & & $1.1 \mathrm{~V}$ & r.ی & Yq & الضابطة & \\
\hline \multirow{2}{*}{.$r$} & \multirow{2}{*}{$1 . r$} & \multirow{6}{*}{$r, r$} & \multirow{6}{*}{$\leqslant 9$} &. .70 &..$\varepsilon \Lambda$ & ro & التجريبية & \multirow{2}{*}{ التركيب } \\
\hline & & & & .00 & ו & $r q$ & الضابطة & \\
\hline \multirow{2}{*}{ • } & \multirow{2}{*}{.98} & & & $1 . \varepsilon$ & Y. & ro & التجريبية & \multirow{2}{*}{ التقويم } \\
\hline & & & &.$\Delta 1$ & $r . \varepsilon Y$ & rq & الضابطة & \\
\hline \multirow{2}{*}{.01} & \multirow{2}{*}{.97} & & & $r . \Delta r$ & 14.94 & ro & التجريبية & \multirow{2}{*}{ مستويات } \\
\hline & & & & r.r. & $1 \leq . \leq 7$ & $r q$ & الضابطة & \\
\hline
\end{tabular}

يوضح الجدول ( • 1) عدم وجود فروقٍ ذات دلالةٍ إحصائيةٍ بين متوسطَي درجات مجموعتَي الاراسة في التطبيق القبلي لاختبار المفاهيم الثرعية في مستوياته المعرفية الستة، وكذلك في الارجة الكلية؛ حيث بلغت قيمة "ت" المحسوية لمستويات الاختبار المعرفية

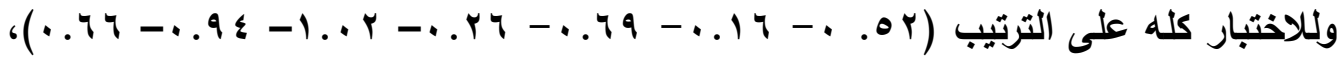
وهي قيمُ أقل من قيمة "ت" الجدولية؛ مما يدل على عدم وجود فروقِ ذات دلالةٍ إحصائيةٍ بين مجموعتَي الدراسة، ومن ثم تكافؤ المجموعتين في متغير المفاهيم الشرعية. وتم التطبيق القبلي لاختبار مهارات التفكير الاستدلالي؛ للتحقق من تكافؤ المجموعتين في مهارات التفكير الاستدلالي، ويعد تصحيح الاختبار تم استخدام اختبار "ت" لمجموعتين

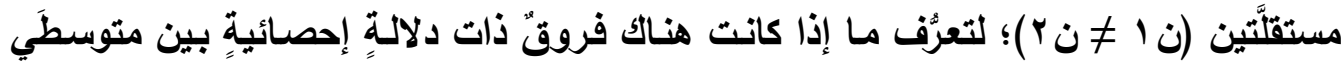
درجات مجموعتَّي الاراسـة في اختبار مهارات التفكير الاستـلالي القبلي، ويحسـاب قيمـة "ت" تم التوصل إلى النتائج الموضحة في الجدول(1 1 ) الآتي: 
أنموذج مقترح لتطوير تدريس العلوم الشرعية في ضوء نهج النظم المتداخلة ....

\begin{tabular}{|c|c|c|c|c|c|c|c|c|}
\hline مستوى الدلالة & 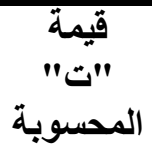 & "قيمة" & الحرية & الانحرياري & المستوسطي & العدد & المجموعة & المهارة \\
\hline \multirow{2}{*}{$\because v \cdot$} & \multirow{2}{*}{.$r q$} & \multirow{4}{*}{$r, \cdot r$} & \multirow{4}{*}{$\varepsilon 9$} & $r, \wedge \wedge$ & IY.YE & ro & التجريبية & \multirow{2}{*}{ الاستتباط } \\
\hline & & & & & $11 . \wedge \Lambda$ & $r q$ & الضابطة & \\
\hline \multirow[b]{2}{*}{$\because V r$} & \multirow[b]{2}{*}{ or } & & & $r, 17$ & Ir... & ro & التجريبية & \multirow[b]{2}{*}{ الاستقراء } \\
\hline & & & & ع & $11 . v r$ & rq & الضابطة & \\
\hline \multirow{2}{*}{$\cdot \varepsilon r$} & \multirow{2}{*}{.$\vee \vee q$} & \multirow{4}{*}{$r, r$} & \multirow{4}{*}{$\varepsilon q$} & $r, \wedge r$ & $1 . . \wedge \varepsilon$ & ro & التجريبية & \multirow{2}{*}{ الاستتتاج } \\
\hline & & & & $r, v r$ & 11.87 & $r q$ & الضابطة & \\
\hline \multirow{2}{*}{. .99} & \multirow{2}{*}{$\because \cdot r$} & & & $0,1 \mathrm{r}$ & r. & ro & التجريبية & \multirow{2}{*}{ كهار الاختبار } \\
\hline & & & & $7, \wedge 1$ & ג.. & rq & الضابطة & \\
\hline
\end{tabular}

يوضـح الجـدول (11) عدم وجـود فـروقٍ ذات دلالـةٍة إحصـائيةٍ بـين متوسـطي درجـات مجموعتَي الدراسة في التطبيق القبلي لاختبار مهارات التفكير الاستدلالي في مهاراته الثلاث،

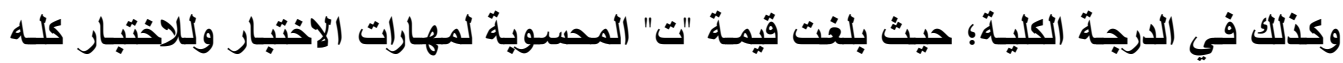

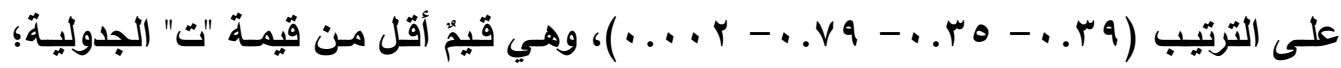

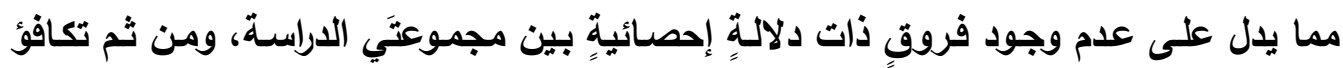
المجموعتين في متغير مهارات التفكير الاستدلالي.

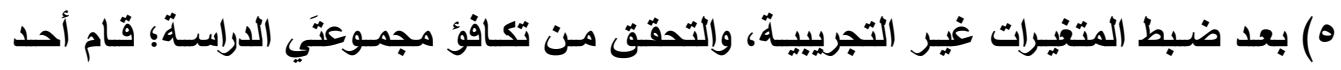
الباحثين بعقد لقاعِ تمهيديٍٍ مـع تلاميذ المجموعة التجريبية؛ بهدف تهيئتهم، وتعريفهم بالتدريس في ضـوء نهج النظم المتداخلـة، ودور التلميذ ضمن إجراءات التنفيذ وفقاً للأنموذج المقترح.

ז) البدء بتدريس مجموعتَي الدراسة، لمدة (ه) أسابيع، بواقع (حصتين) أسبوعيًاً. V بعد الانتهاء من تدريس مجموعنَّي الاراسة تم التطبيق البعدي لأدوات الاراسة. 


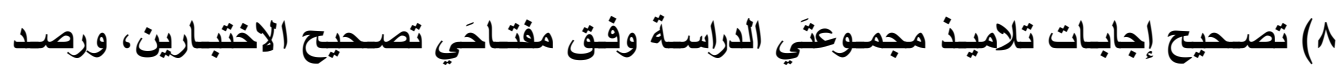
درجاتهم؛ لمعالجة البيانات إحصائيّاً وتحليلها، واستخلاص النتائج، ومن ثم التم التحقق من

$$
\text { فروض الاراسة. }
$$

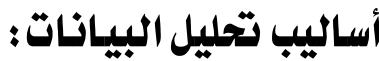

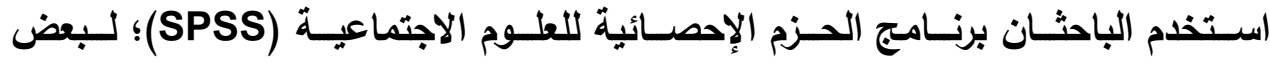

المعالجات الإحصائية المتبعة في هذه الاراسة، وقد تم استخدام الأساليب الإحصائية الآتية: 1) التكرارات والنسب المئوية؛؛ لحساب الاتفاق والاختلاف بين آراء المحكمين، ولبنـاء جدولَّي المواصفات لاختبارَي المفاهيم الشرعية ومهارات التفكير الاستدلالي.

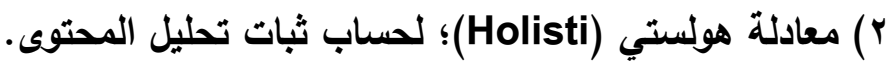

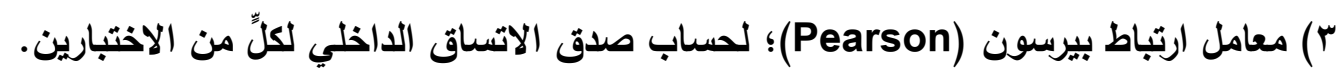

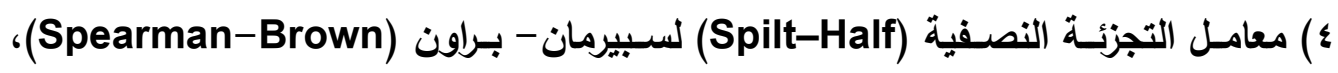
ومعامل ثبات ألفا كرونباخ (Cronbach's Alpha)؛ لحساب ثبات كلٍّ من الاختبارين. ه) معاملات السهولة والصعوية لأسئلة كلٍّ من الاختبارين.

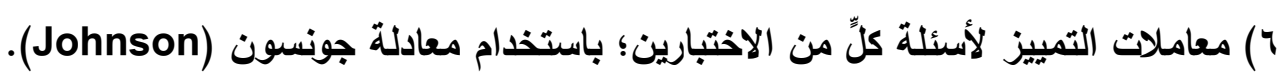

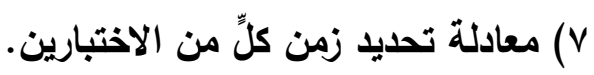

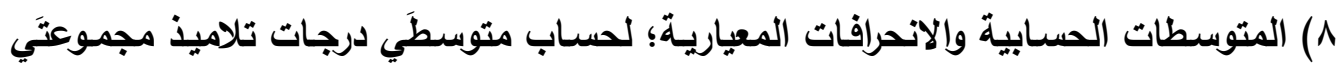

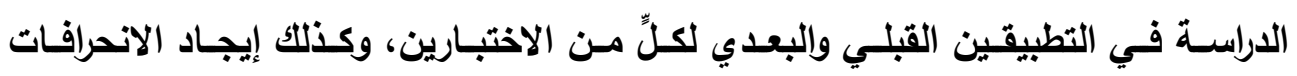
المعيارية لارجاتهم. 9) اختبار (ت) لمجموعتين مستقلَّتين (Independent Sample T-test)؛ للتحقق من دلالـة الفروق بين متوسطَ أعمـار تلاميذ مجموعتَي الدراسـة، ودرجـاتهم في التطبيقين القبلي والبعدي لكلٍّ من الاختبارين.

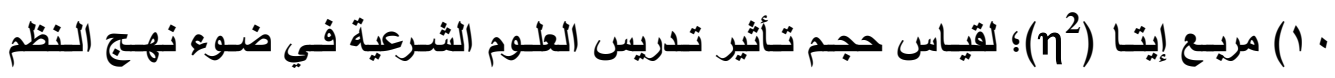
المتداخلة وفقاً للأنموذج المقترح، وذلك من خلال استخدام المعادلة الآتية:

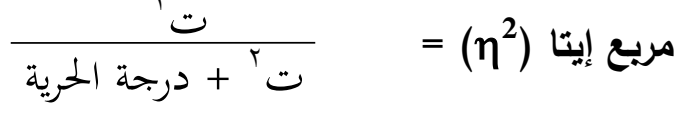




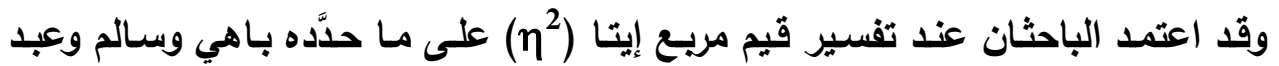

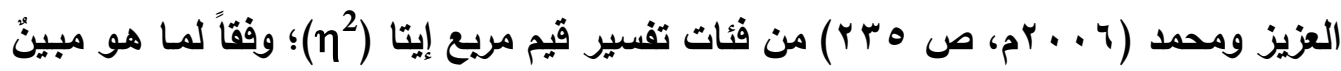
في الجدول (r I) الآتي:

الجدول(r I ): قيم مربع إيتا (n2)

\begin{tabular}{|c|c|}
\hline حجم التأثيّر & قيمة مربع إيتا ( \\
\hline صغير &. .1 \\
\hline متوسط & $\because \cdot 7$ \\
\hline كبيز &. .18 \\
\hline
\end{tabular}

نتائج اللدراسة ومنـاقشتها وتفسيرهـا : عُرضت نتائج الدراسة من خلال الإجابة عن أسئلتها، ومناقشة هذه النتائج وتفسيرها، وذلك على النحو الآتي: نتائج الدراسة المرتبطة بالسؤال الأول: حيث نــنَّ السوأل الأول على الآتـي: "مـا المفـاهيم الشـرعية المـراد إكسـابها في العلـوم الشرعية لتلاميذ الصف السادس الابتائي؟"، وللإجابة عن هذا السؤال قام الباحثان بالاطلاع على البحوث والدراسـات السـابقة التي تناولت أسساليب تحليل المحتوى؛ للإفادة من منهجيتها التي اتبعتها في عملية التحليل، ومن ثم قاما بالاطلاع على أهداف تدريس وحدة "الزكاة" من

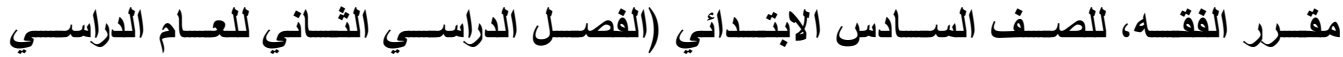

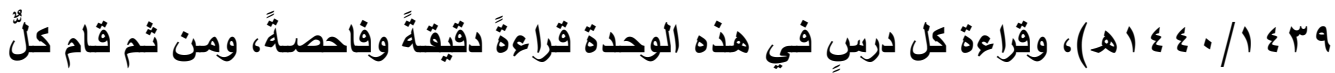
من الباحثين بعملية التحليل على حدةٍ؛ ومن ثم التحقق من ثبات تحليل المحتوى، ويعد ذلك عرض قائمسة المفـاهيم الشـرعية على مجموعةٍ من المحكمين من ذوي الاختصساص في هذا المجال؛ للتأكد من سلامتها العلمية واللغوية، ويبان مدى مناسبتها، ومن ثم تعديلها في ضوع

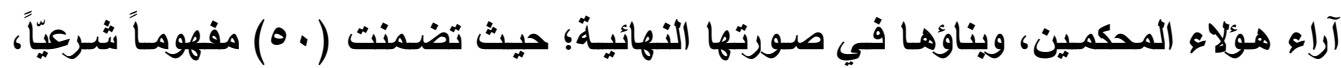
والجدول (T I) الآتي يوضح هذه القائمة: 
أنموذج مقترح لتطوير تدريس العلوم الشرعية في ضوء نهج النظم المتداخلة ....

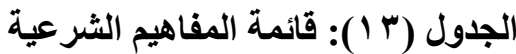

\begin{tabular}{|c|c|c|c|}
\hline المفهوم الشرعي & م & المفهوم الشرعي & r \\
\hline نصاب عروض التجارة & ry & الزكاة & 1 \\
\hline الخارج من الأرض & rV & الآية & $r$ \\
\hline نصاب الحبوب والثمار & $r \Lambda$ & الحديث & $r$ \\
\hline الصاع التبوي & rq & الفقراء & $\varepsilon$ \\
\hline بهيمة الأنعام & $r$ & الإسلام & 0 \\
\hline السائمة & $M$ & الثهادتان & 7 \\
\hline نصاب الإبل & rr & الصلاة & $\mathrm{V}$ \\
\hline نصاب البقز & $r \mu$ & صوم رمضان & $\Lambda$ \\
\hline نصاب الغتم & $r \varepsilon$ & حج البيت & 9 \\
\hline المحرَّم & ro & الصدقة & 1. \\
\hline الإخلاص & rq & الواجب & 11 \\
\hline مستحقو الزكاة & $M V$ & المنٌّ & Ir \\
\hline تطهيز المال & $\mathrm{r \Lambda}$ & الأذى & ir \\
\hline تطهير النفس & rq & منع الزكاة & $1 \varepsilon$ \\
\hline المساكين & $\varepsilon$. & الإثثم & 10 \\
\hline العاملون على الزكاة & $\varepsilon 1$ & الكافز & 17 \\
\hline المؤلفة قلوبهم & $\varepsilon Y$ & النَصاب & IV \\
\hline الرقاب & $\varepsilon r$ & مضي الحول & 11 \\
\hline الغارمون & $\leqslant \leq$ & الأموال الزكوية & 19 \\
\hline في سبيل الله & $\leqslant 0$ & شكر الله & r. \\
\hline ابن السبيل & $\varepsilon 7$ & النقدان & YI \\
\hline إعتاق العبيد & $\varepsilon V$ & نصاب الذهب & Yr \\
\hline إعتاق المكاتَبين & $\varepsilon \Lambda$ & نصاب الفضة & $r \mu$ \\
\hline الإصلاح بين الناس & $\varepsilon q$ & نصاب الأوراق النقدية & $r \varepsilon$ \\
\hline الجهاد & 0 . & عروض التجارة & ro \\
\hline
\end{tabular}

تتائج الدراسة المرتبطة بالسؤال الثاني:

نصَّ السؤال الثاني على الآتي: "ما الأنموذج المقترح لتطوير تلريس العلوم الثرعية في ضوء نهج النظم المتذاخلة؟"، وللإجابة عن هذا السؤال قام الباحثان بالاطلاع على البحوث والدراسات السابقة والأدبيات التي تناولت النماذج التدريسية بشكلٍ عامًا والتدريس في ضوء نهج النظم المتاخلة بشكلٍ خاصٍٍ، والاطلاع على خصائص النمو لاى تلاميذ الصف السـادس

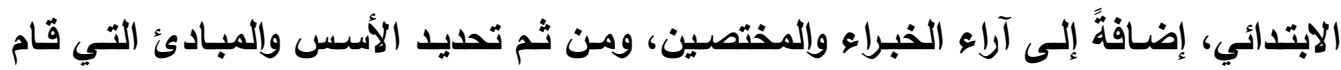
عليها الأنموذج المقترح، ويناؤه وتصميمه في صورته الأولية، والتحقق من صدقه من خلال عرضه على مجموعةٍ من المحكمين من ذوي الاختصاص في هذا المجال؛ للتأكد من مناسبته 
لتطوير التدريس في ضوء نهج النظم المتداخلة، ومرونته، وسلامته العلمية واللغوية، ومن ثم تعديله في ضوء آراء هؤلاء المحكمين، ويناؤه في صورته النهائية؛ حيث تضمن المراحل

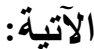

المرحلـة الأولى: إثـارة انتبـاه التلاميـذ للـدرس: يقوم المعـم بتثـويق التلاميـذ، وإثـارة انتباههم، وزيادة دافعيتهم؛ لإشراكهم في التفكير بموضوع الدرس، واستكشاف العلاقات بين العلوم المتنوعة؛ وذلك من خلال عرض بعض المواقف والأحداث أو الصور أو النماذج أو الو لوات العينات أو مقاطع الفيديو، المتضمنة لمعلوماتٍ أو مشكلاتٍ أو قضايا واقعيةٍة مرتبطةٍ بالأفكار

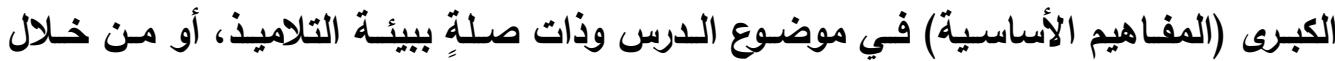
عرض بعض الخبرات التي يمر بها التلاميذ، أو عن طريق طرح المعلم لبعض الأسئلة التي

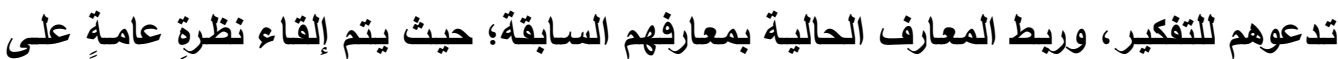
الأفكار الكبرى (المفاهيم الأساسية) في موضوع الارس، ومناقشتهم حولها. المرحلة الثانية: استكثاف احتياجات التلاميذ في الدرس: يوجه المطلم التلاميذ للتركيز على الأفكار الكبرى (المفاهيم الأساسية) في موضوع الدرس، ومن ثم استكثاف احتياجاتهم

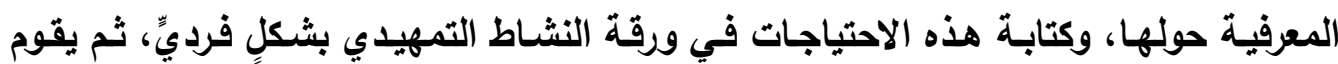
المعلم بمناقشتهر حولها، ومن ثم تلخيصها وكتابتها أمامهر على السبورة. المرحلة الثالثة: طرح الأسئلة الجوهرية: يقوم المعلم مع التلاميذ بصياغة أسئلةٍة جوهريةٍ

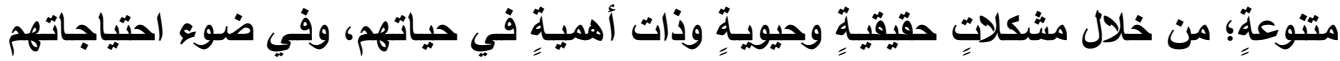
حول الأفكار الكبرى (المفاهيم الأساسية) في الدرس -التي تم التوصل إليها في المرحلة الثانية وكتابتها -، ويجب أن يثعروا بالحاجة إلى البحث والتتقيب في العلوم المتنوعة، وأن تؤدي هذه الأسئلة إلى الاستقصاء والجدل؛ للوصول إلى الإجابة عنها. وهذه المرحلة تتصف

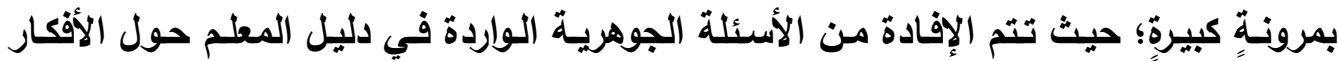

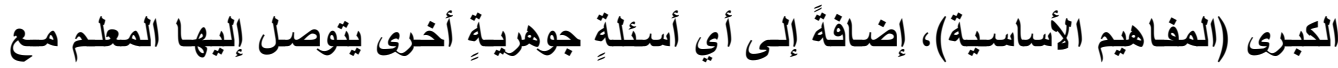
التلاميذ في ضوء احتياجاتهم حول تلك الأفكار الكبرى (المفاهيم الأساسية)؛ إذ يقوم بإضافة الكافية ما يراه مناسباً منها إلى أولق النشاط. 
المرحلة الرابعة : البحث والاستقصاء: يقوم المعلم بتقسيم التلاميذ إلى مجموعاتِ صغيرةٍ غير متجانسةٍ؛ لتقوم كل مجموعةٍ بالعديد من الأنشطة التي تتطلب البحث والاستقصاء، ومن

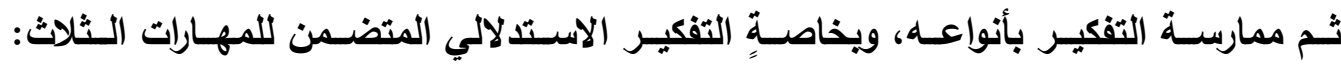
"الاستتباط، والاستقراء، والاستتنتاج"؛ وذلك مـن أجل الإجابـة عن الأسئلة الجوهريـة بصورةٍ

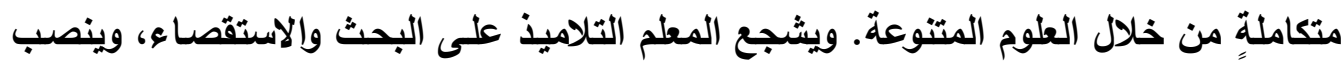
دوره على تزويـدهم بـالمواد، والأدوات، ومصـادر التعلم، وتوجيـه اهتمامـاتهم واستفســاراتهم؛

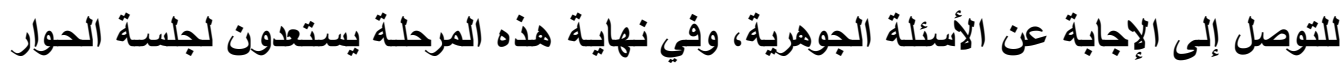
مع معلمهم وزملائهم؛ لعرض ما توصلوا إليه من إجاباتٍ. المرحلة الخامسلة: توضيح الأفكار الكبرى (المفاهيم الأساسية): يقوم التلاميذ بعد البحث والاستقصاء بعرض مـا توصلوا إليهه من إجاباتٍ عن الأسئلة الجوهريـة على معلمهم وزملائهم، ومن ثم مناقشتها؛ لتوضيح الأفكار الكبرى (المفاهيم الأساسية)، وتقديمها بصورةٍ

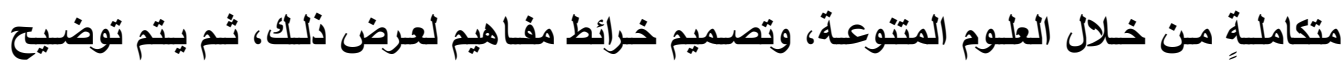
المفاهيم الشرعية كافةً، وإعادة تثكيل معارف التلاميذ بما يضمن لهم التعلم ذا المعنى.

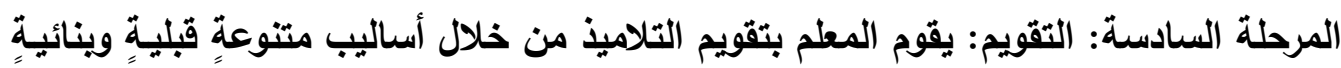

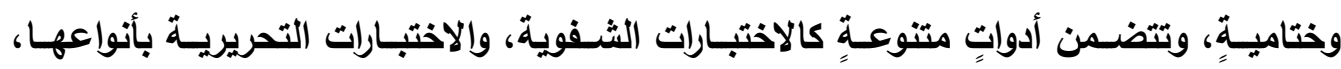

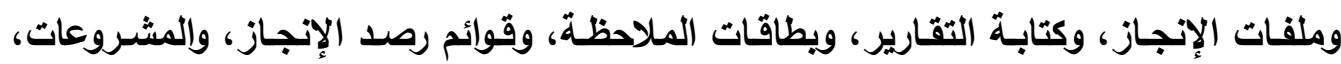
واللقاءعات الفردية والجماعية مع التلاميذ، ونحوها. 
والثكل( ) الآتي يوضح مراحل الأنموذج المقترح السابقة لتطوير تدريس العلوم الثرعية في ضوء نهج النظم المتداخلة:

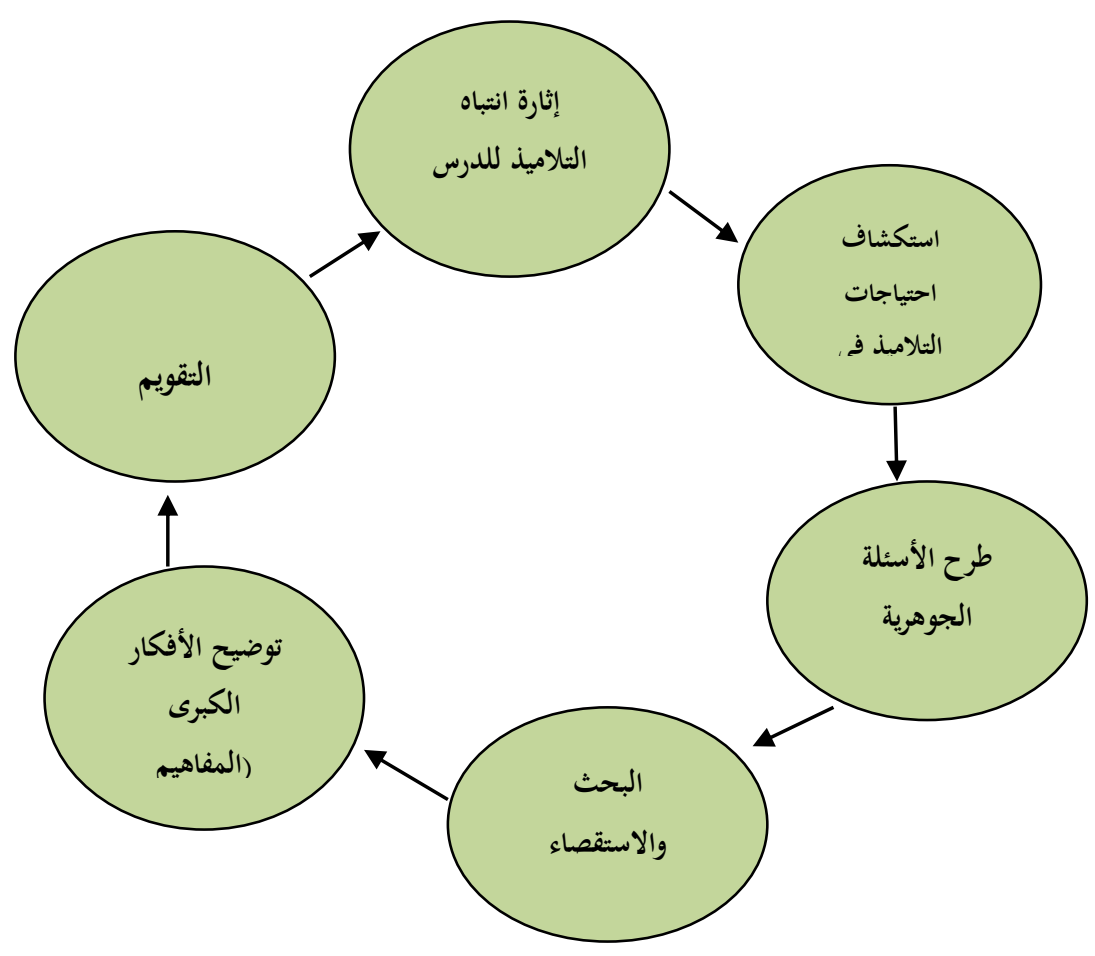

الثكل ( ) : مراحل الأنموذج المقترح السابقة لتطوير تدريس العلوم الثرعية

تتائج الدراسة المرتبطة بـالسؤال الثالث ومناقشتها وتفسيرهـا :

حيث نصَّ السؤال الثالث على الآتي: "ما فاعلية تطوير تدريس العلوم الشرعية في ضوء نهج النظم المتداخلة في إكساب المفاهيم الشرعية لتلاميذ الصف السادس الابتدائي في مدينة

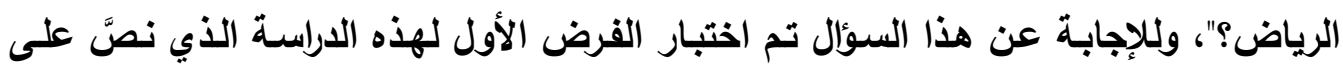

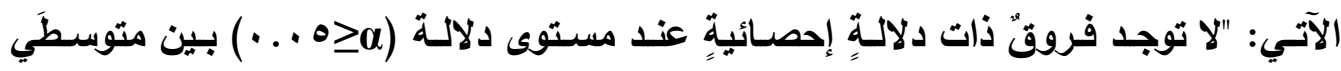
درجـات تلاميـذ المجمـوعتين التجريبيـة والضـابطة فـي التطبيـق البعـدي لاختبـار المفــاهيم 
ولاختبار صحة هذا الفـرض حُسب المتوسط الحسـبي، والانحراف المعيـاري، واستخدام

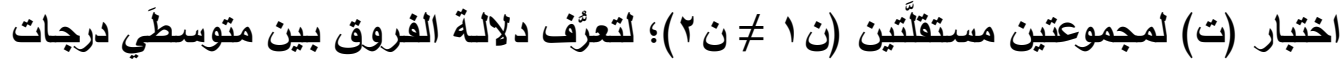
تلاميذ المجموعتين التجريبية والضابطة في التطبيق البعدي لاختبار المفاهيم الثرعية، كما تم

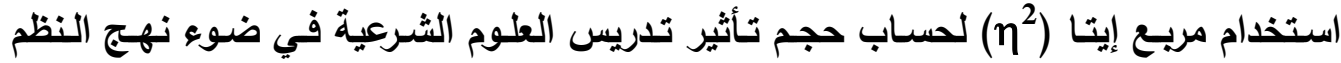
المتداخلة وفقاً للأنموذج المقترح في إكساب المفاهيم الشرعية لتلاميذ المجموعة التجريبية، وتم التوصل إلى التتائج الموضحة في الجدول (ع أ) الآتي: الجدول (ع 1): متوسطَ درجات تلاميذ المجموعتين التجريبية والضابطة في التطبيق البعدي لاختبار المفاهيم الشرعية الثرية الميلة

\begin{tabular}{|c|c|c|c|c|c|c|c|c|c|}
\hline مربع & مستوى الالاكة & 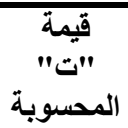 & 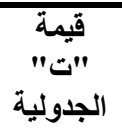 & الحرية & الانحراف & الحستوسط & العدد & المجموعة & المعرفي \\
\hline \multirow{2}{*}{$\because \leqslant V$} & \multirow{2}{*}{$\because \cdots$} & \multirow{2}{*}{7.07} & \multirow{14}{*}{$r, r$} & \multirow{14}{*}{$\leqslant q$} & 1.17 & $V . \varepsilon \varepsilon$ & ro & التجريبية & \multirow{2}{*}{ التذكر } \\
\hline & & & & & 1.01 & $\varepsilon . \wedge \wedge$ & YY & الضابطة & \\
\hline \multirow{2}{*}{ o } & \multirow{2}{*}{$\because \cdots$} & \multirow{2}{*}{$0.1 Y$} & & & Y.Y. & 1.7. & ro & التجريبية & \multirow{2}{*}{ الفهم } \\
\hline & & & & & r.00 & 0.19 & Y & الضابطة & \\
\hline \multirow{2}{*}{.9} & \multirow[b]{2}{*}{$\because \cdots$} & \multirow{2}{*}{$\Lambda . \Delta r$} & & & .07 & 7.71 & ro & التجريبية & \multirow{2}{*}{ التطبيق } \\
\hline & & & & & 1.97 & 1.70 & Y & الضابطة & \\
\hline w & & 714 & & &. .70 & $7.0 Y$ & ro & التجريبية & 4 \\
\hline$\because 6$ & 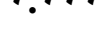 & .19 & & & r.r & o... & Y & الضابطة & العتيك \\
\hline 47 & & $9 \times=$ & & & $\because \cdots$ & r... & ro & التجريبية & الت \\
\hline & $\because$ & & & &. .79 & .70 & $r q$ & الضابطة & 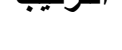 \\
\hline & & 404 & & & ס $1 . r$ & 0.71 & ro & التجريبية & \\
\hline 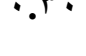 & $\because \cdots$ & 2.07 & & & $1.0 r$ & r.^o & $r q$ & الضابطة & الهويم \\
\hline & & & & & $\varepsilon . \cdot \varepsilon$ & rr.qr & ro & التجريبية & كل \\
\hline .7. & $\because \cdots$ & 1.77 & & & 7.17 & r. & Y & الضابطة & الاختبار \\
\hline
\end{tabular}

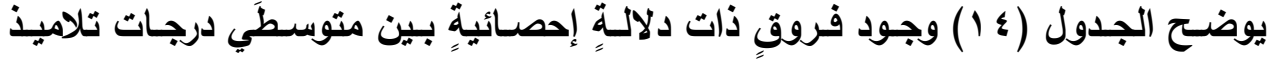
المجموعتين التجريبية والضابطة في التطبيث البعدي لاختبار المفاهيم الشرعية في مستوياته المعرفية الستة، وكذلك في الارجة الكلية؛ حيث بلغت قيمة "ت" المحسوبة لمستويات الاختبار المعرفية وللاختبار كته على الترتيب (Y (

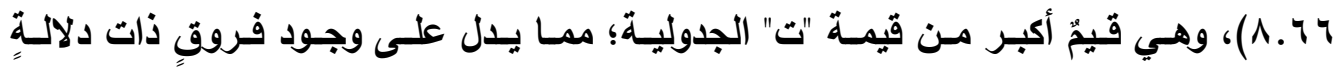


إحصائيةٍ بين مجموعتَي الاراسـة التجريبية والضـابطة في اختبار المفاهيم الثرعية لصالح المجموعة التجريبية. ولتعرُّف حجم تأثير تدريس العلوم الثرعية في ضوء نهج النظم المتلاخلة وفقاً للأنموذج

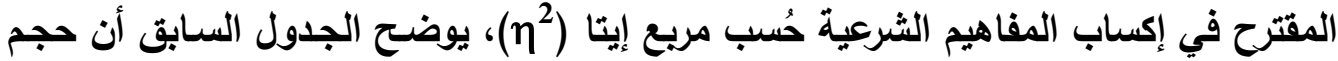

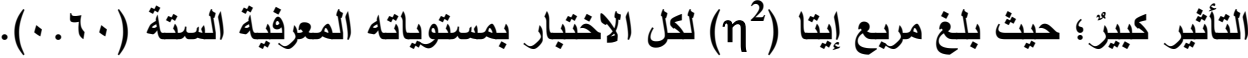
ولحساب فاعلية تدريس العلوم الثرعية في ضوء نهج النظم المتداخلة وفقاً للأنموذج

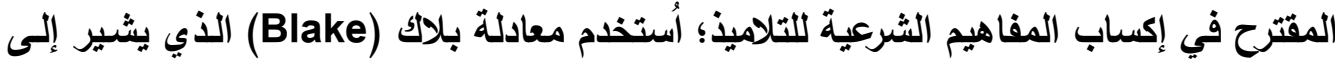
أن نسبة الكسب المعدل إذا كانت تقع بين الصفر والثواحد الصحيح (•-1 ) فإنها يمكن الحكم

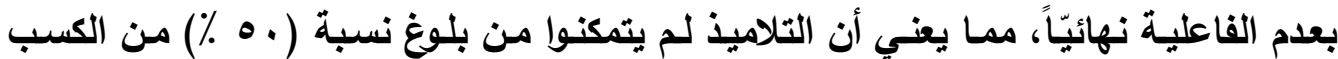

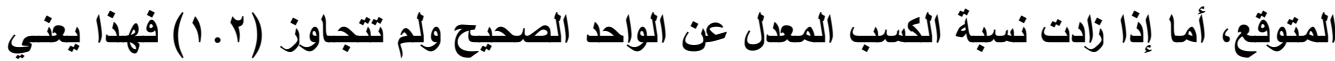

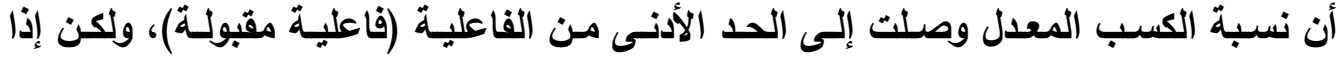

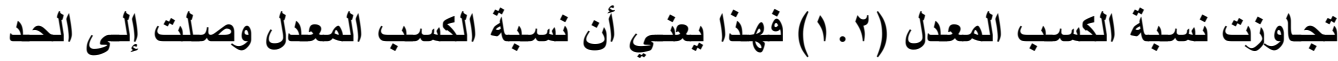
الأقصى للفاعلية (قاعلية عالية)، حُسبة نسبة الكسب المعدل وفقاً للمعادلة الآتية:

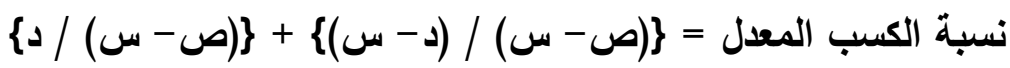
حيث ص: متوسط درجة الاختبار البعدي، س: متوسط درجة الاختبار القبلي، د: الارجة

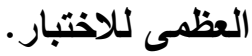

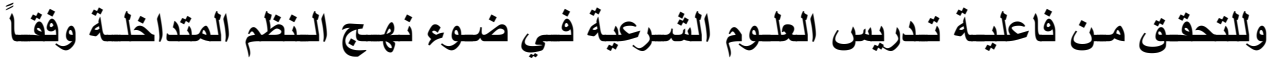
للأنموذج المقترح في إكساب المفاهيم الثرعية للتلاميذ؛ حُسب المتوسط الحسابي للارجات

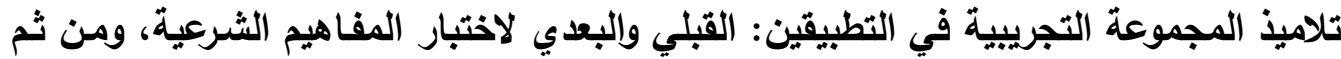
حساب نسبة الكسب المعدل للاختبار، والجدول الآتي (ه 1 ) يوضح ذلكك: 
أنموذج مقترح لنطوير تدريس العلوم الشرعية في ضوء نهـج النظم المتداخلة .

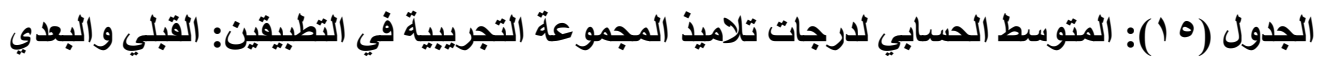
لاختبار المفاهيم الشرعية الثمية

\begin{tabular}{|c|c|c|c|c|c|}
\hline الفاعلية & الكسب المعدل & لالدرجة & المتسابي البعدي & الحسبابي القبلي & المستوفي \\
\hline كبيرة & $1 . Y Y$ & 9 & $\ddot{V} . \varepsilon \varepsilon$ & $\dot{r} . \wedge$ & التذكر \\
\hline متوسطة & 1.10 & 11 & 1.7. & $r . \varepsilon \varepsilon$ & الفهم \\
\hline كبيرة & 1.00 & $\varepsilon$ & $r .71$ & 1.2 & التطبيق \\
\hline كبيزة & $1 . r 0$ & V & $7.0 Y$ & r.VY & التحليل \\
\hline كبيزة & 1.87 & $r$ & r... &..$\leqslant \Lambda$ & التركيب \\
\hline كبيرة & $1 . Y r$ & V & 0.71 & Y.17 & التقويم \\
\hline كبيرة & $1 . r V$ & $\varepsilon$. & r.q. & Ir.qr & كل مستويات الاختبار \\
\hline
\end{tabular}

ويوضت الجدول (0 1) أن نسبة الكسب المعدل لكل الاختبار بمستوياته المعرفية الستة

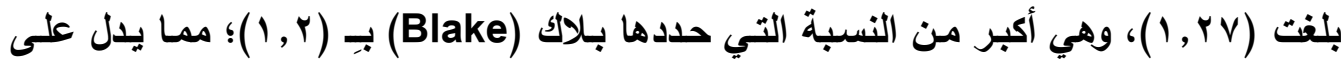

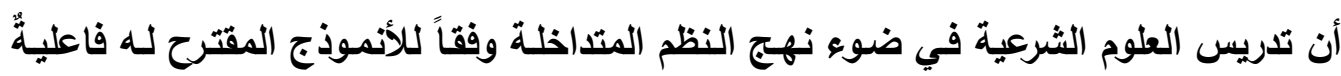
كبيرةٌ في إكساب المفاهيم الشرعية للتلاميذ. واتفقت هذه التتيجة بشكلٍ واضِحٍ فيما يتعلق بالمتغير المستقل (التدريس باستخدام نهج النظم المتداخلة) والمتغير التابع الأول (إكساب المفاهيم الشرعية للتلاميذ) مع نتائج دراستَي Sagdic ديميرل وكوسكن (Demirel and Coskun, 2010) سـاجديك وديميركايا (للتين اتخذتا التدريس باستخدام نهج النظم المتداخلة متغيراً (and Demirkaya, 2014) مستقلًّ، وأظهرث نتائج دراسـة (ديميرل وكوسكن (Demirel and Coskun, 2010) الأثر الكبير لنهج النظم المتداخلة في تطوير قدرة التلاميذ على إقامـة روابط بين المفاهيم الحاليـة والمفـاهيم التي سـبق لهـم تعلمهـا، كمـا أظهـرث نتـائج دراسـة سـاجديك وديميركايـا (الدور الإيجابي لنهج النظم المتداخلة في ترسيخ (Sagdic and Demirkaya, 2014) مفاهيم الموضوع الدراسي. كما اتفقت هذه التتيجة فيمـا يتعلق بـالمتغير المستقل (التدريس باستخدام نهج النظم المتداخلة) مع نتائج دراسـة كلٍ من (بريستو 2012 Bristow, 2012 ) دينيمسي وأدا (B. Park and Mills, )؛ بـارك وميلز (Deneme and Ada

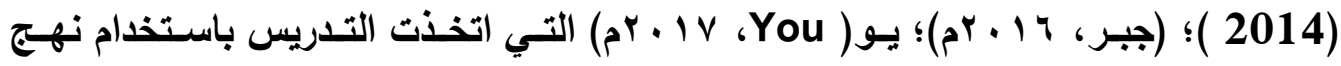
النظم المتداخلة متغيراً مستقلًّ، وأظهرث نتائجها الأثر الكبير في عددٍ من المتغيرات التابعة. 
ويمكن عزو نتيجـة السـوأل الثالث ـالتي تـلـل على الفاعليـة الكبيـرة لتـريس العلـوم الثرعية في ضوء نهج النظم المتداخلة وفقاً للأنموذج المقترح في إكساب المفاهيم الثرعية للتلاميذ- إلى ما يأتي:

( ) أسـهمت مبـادئ النظريـة البنائيسة التي يقوم عليهـا الأنمـوذج المقترح في جعل التلاميذ

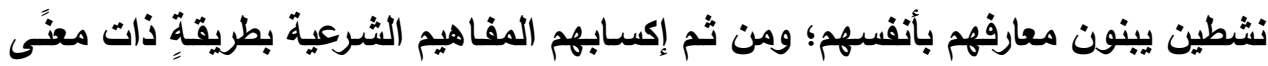

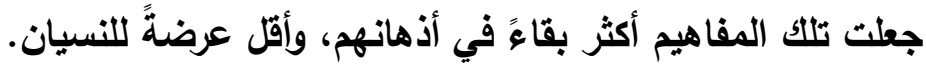
r) أدى الأنمـوذج المقترح إلى توصل التلاميذ للأفكار الكبرى (المفـاهيم الأساسية) بصـورةٍ متكاملةٍ وشاملةٍ وواضحةٍ من خلال العلوم المتنوعة، ومن ذلك المفاهيم الشرعية ضمن

\section{جميع المستويات المعرفية.}

r) أكد الأنموذج المقترح على ضرورة مواجهة التلاميذ بمشكلاتٍ حقيقيةٍة من الواقع وذات صـلةٍ بحيـاتهم، ومـن ثم ربـط المعـارف الحاليـة بمعـارفهم السـابقة لاكتشـاب المفــاهيم الثرعية بطريقةٍ ذات معنَّ؛ مما أدى إلى بقاء أثر التعلم والاحتفاظ بالمفاهيم الثرعية

لفترةٍ طويلةٍ. ؛) أسـهم الأنمـوذج المقترح في تنميـة مهـارات التفكير الاستـلالي لـى التلاميذ التي تُعدُّ

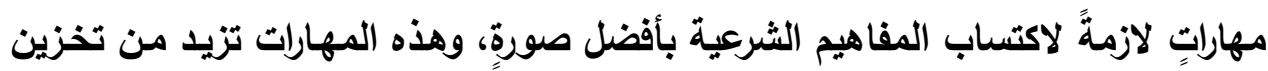
المفاهيم في الذاكرة بعيدة المدى، وتجعل استخدامها في مواقف متنوعةٍ في المستقبل أمراً ممكناً وسهلاً.

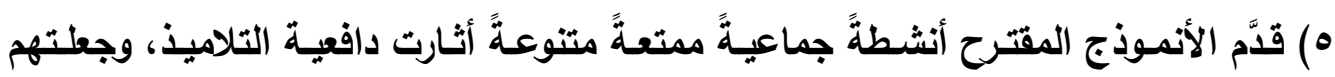

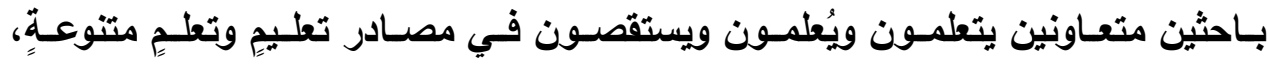
ويمارسـون مهارات التفكير الاستـلالي؛ لاكتسـاب الأفكار الكبرى (المفـاهيم الأساسية) ومن ثم المفاهيم الشرعية بشكلٍ واضحٍ. 7) ركزت المرحلة الخامسـة من مراحل الأنموذج المقترح (توضيح الأفكار الكبرى "المفاهيم

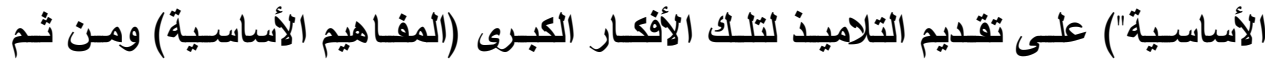
المفـاهيم الثـرعية بصـورةٍ متكاملـةٍة مسن خـلال العلوم المتنوعـة، وتصميم خرائط مفـاهيم لعـرض ذلـك وتلخيصـه وإبـراز العلاقـات والـروابط بـين المفـاهيم الأساسـية، ثـم توضسيح المفاهيم الشرعية كافةً، وإعادة تثكيل معارف التلاميذ بما يضمن لهم التعلم ذا المعنى. 


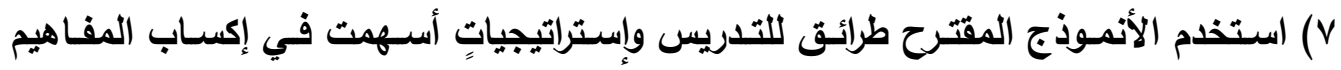

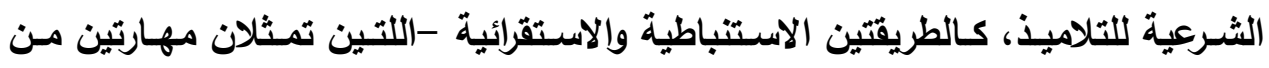

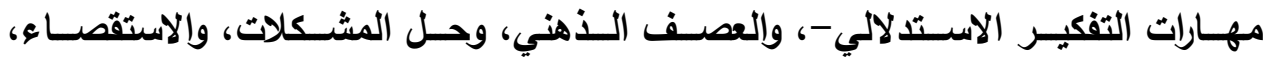
والاكتثاف، والحوار والمناقشثة، وخرائط المفاهيم.

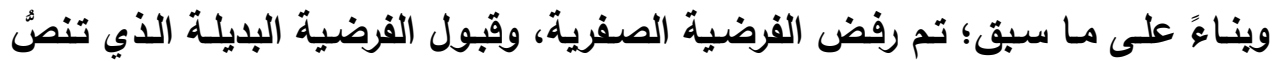

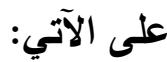

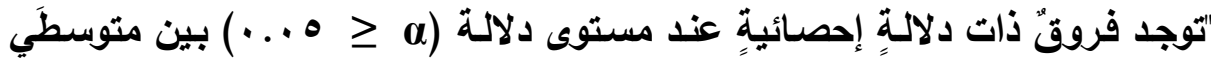
درجـات تلاميـذ المجــوعتين التجريبيـة والضـابطة فـي التطبيـق البعدي لاختبـار المفــاهيم الثرعية، لصالح المجموعة التجريبية". تتائج الدراسة المرتبطة بالسؤال الرابع ومناقثتها وتفسيرها :

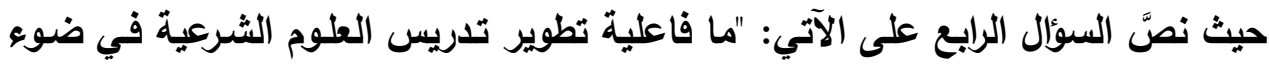

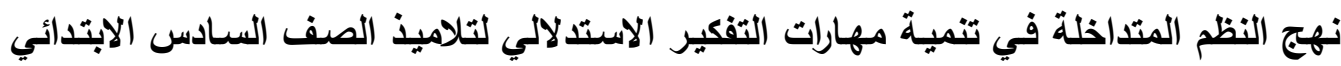

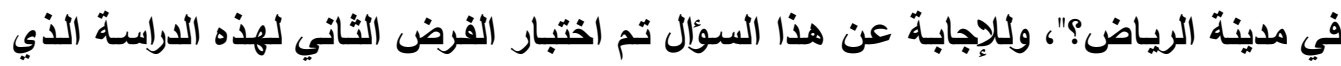

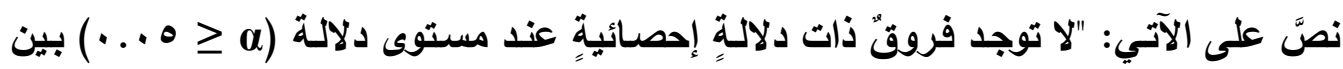
متوسطَي درجات تلاميذ المجموعتين التجريبية والضابطة في التطبيق البعدي لاختبار مهارات

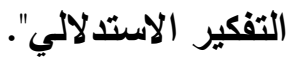
ولاختبار صحة هذا الفرض حُسب المتوسط الحسابي، والانحراف المعياري، واستخدام

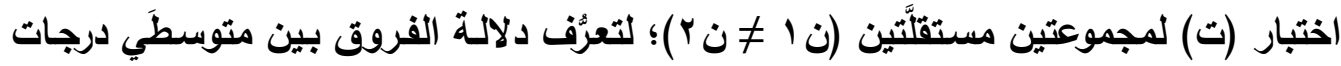

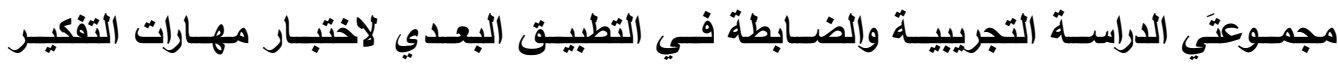

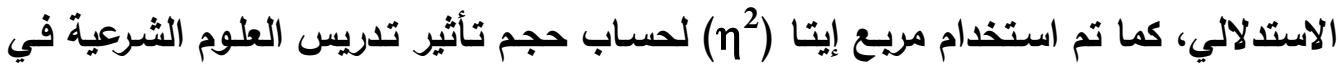

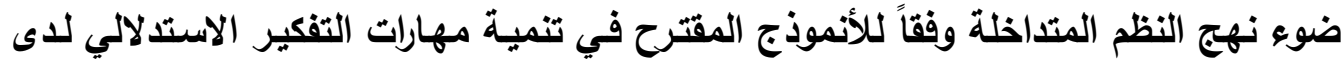
تلاميذ المجموعة التجريبية، وتم التوصل إلى النتائج الموضحة في الجدول(7 1 ( ) الآتي: 
أنموذج مقترح لتطوير تدريس العلوم الشرعية في ضوء نهج النظم المتداخلة ...

الجدول (7 ا ): متوسطَ درجات مجموعنَي الاراسة التجريبية والضابطة في التطبيق البعدي لاختبار

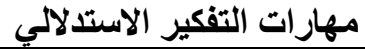

\begin{tabular}{|c|c|c|c|c|c|c|c|c|c|}
\hline مربع & الدلالة & "المحسوبة & "قاتية" & الحرجية & المعياري & الحستوسبي & العدد & المجموعة & المهارة \\
\hline \multirow{2}{*}{.91} & \multirow{2}{*}{$\because \cdots$} & \multirow{2}{*}{$10.0 r$} & \multirow{8}{*}{$r, r$} & \multirow{8}{*}{$\leqslant q$} & 1.7. & YY.YY & ro & التجريبية & \multirow{2}{*}{ الاستتباط } \\
\hline & & & & & $r . \cdot r$ & 11.24 & Y4 & الضابطة & \\
\hline \multirow[b]{2}{*}{$\cdot . \wedge V$} & \multirow[b]{2}{*}{$\because \cdots$} & \multirow[b]{2}{*}{ IY. $\varepsilon V$} & & & 1.11 & YY.OY & ro & التجريبية & \multirow[b]{2}{*}{ الاستقراء } \\
\hline & & & & & r.v. & Ir.qr & rq & الضابطة & \\
\hline \multirow{2}{*}{.$V V$} & \multirow{2}{*}{$\because \cdots$} & \multirow{2}{*}{$\Lambda . \leqslant q$} & & & $1 . \varepsilon$. & rI. & ro & التجريبية & \multirow{2}{*}{ الاستنتاج } \\
\hline & & & & & ט.r. & & r & الضابطة & \\
\hline \multirow{2}{*}{.$\wedge \wedge$} & \multirow{2}{*}{$\ldots$} & \multirow{2}{*}{ Ir.IV } & & & r.l. & $77.1 \%$ & ro & التجريبية & \multirow{2}{*}{ كلار } \\
\hline & & & & & $1 . . T_{1}$ & rV.AI & Y & الضابطة & \\
\hline
\end{tabular}

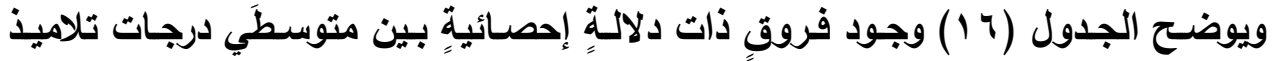

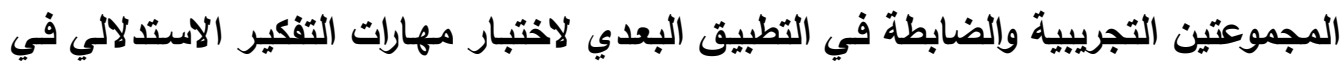

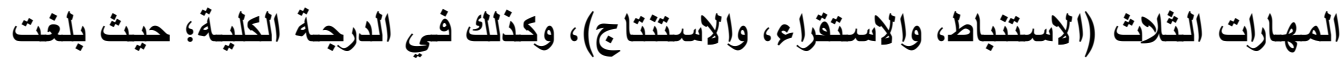
قيمـة "ت" المحسوية لمهارات التفكير الاستـلالي في الاختبـار وللاختبـار كلـه على الترتيب

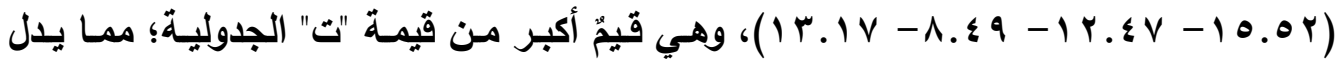
على وجود فروقٍ ذات دلالةٍ إحصائيةٍ بين مجموعنَي الدراسـة التجريبية والضـابطة في اختبار مهارات التفكير الاستدلالي لصالح المجموعة التجريبية. ولتعرُّف حجم تأثير تدريس العلوم الشرعية في ضوء نهج النظم المتداخلة وفقاً للأنموذج

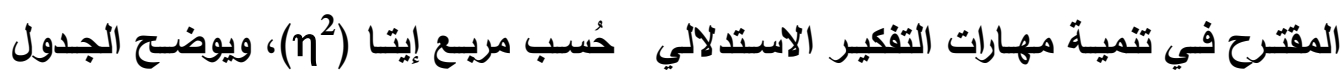

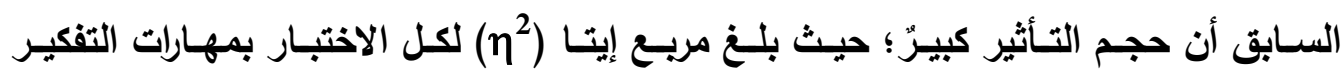

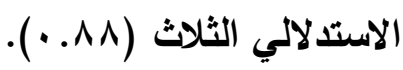
وللتحقـق مـن فاعليـة تـدريس العلـوم الثـرعية في ضـوع نهـج الـنظم المتداخلـة وفقاً

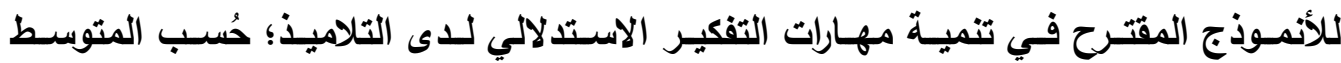
الحسابي لارجات تلاميذ المجموعة التجريبية في التطبيقين: القبلي والبعدي لاختبار مهارات

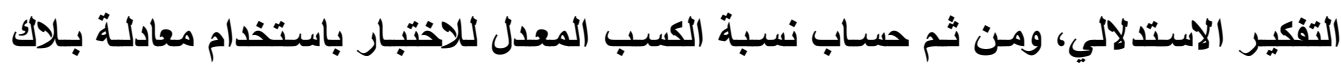

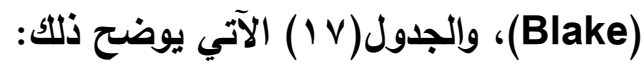


أنموذج مقترح لتطوير تدريس العلوم الشرعية في ضوء نهج النظم المتداخلة ...

الجدول(V I): المتوسط الحسابي لارجات تلاميذ المجموعة التجريبية في التطبيقين: القبلي والبعدي فئي

لاختبار مهارات التفكير الاستدلاكي تلاميد

\begin{tabular}{|c|c|c|c|c|c|}
\hline الفاعلية & الكسب المعدل & العظمى & المتسابي البعدي & المتوسط القبلي & المههارة \\
\hline كبيرة & $1 . Y \Lambda$ & Y $\varepsilon$ & r r.Mr & IY.YE & الاستتباط \\
\hline كبيرة & 1.41 & $Y \varepsilon$ & YY.OY & $1 r_{0} \ldots$ & الاستقز اء \\
\hline كبيرة & $1 . Y Y$ & $r \leq$ & YI.YA & $1 \cdot . \wedge \varepsilon$ & الاستتتاج \\
\hline كبيرة & $1 . Y V$ & VY & $97.1 \mathrm{r}$ & ro.. & كل مهارات الاختبار \\
\hline
\end{tabular}

ويوضسح الجدول (V V) أن نسبة الكسب المعدل لكل الاختبـار بمهاراتهـ الثنلاث بلغت

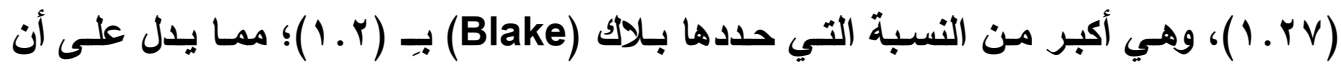
تلريس العلوم الشرعية في ضوء نهج النظم المتداخلة وفقاً للأنموذج المقترح له فاعليةٌُ كبيرةٌ في تتمية مهارات التفكير الاستدلالي لاى التلاميذ.

واتفقت هذه التتيجة بشكلٍ واضحٍ فيما يتعلق بالمتغير المستقل (التدريس باستخدام نهج النظم المتداخلة) والمتغير التابع الثاني (تتمية مهارات التفكير الاستدلالي لـى التلاميذ) مـع تتائج دراستَّي سـاجديك وديميركايا (Sagdic and Demirkaya, 2014)؛ يو You )

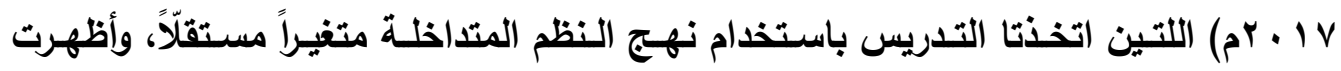
تتائج دراسـة سـاجديك وديميركايا (Sagdic and Demirkaya, 2014) الدور الإيجابي لنهج النظم المتداختة في ممارسـة التلاميذ للتفكير، والقدرة على الاستتناج بسـهولةٍ، كمـا

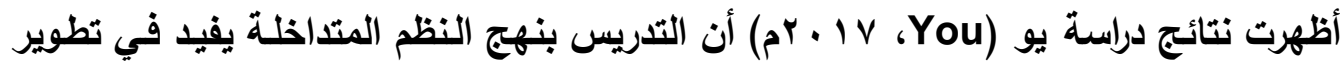
مهارات التفكير الاستدلالي لاى التلاميذ. كما اتفقت هذه التتيجة فيمـا يتعلق بالمتغير المستقل (التدريس باستخدام نهج النظم المتداخلة) مع نتائج دراسة كلٍٍ من ( بريستو Bristow, 2012 ) ؛ دينيمي وأدا (2012 )

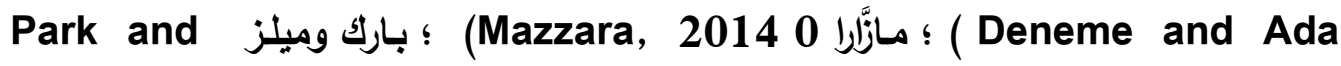

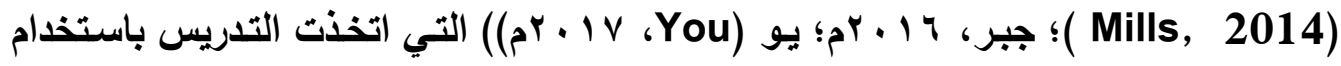
نهجج النظم المتداخلة متغـراً مستقلًّ، وأظهرت نتائجها الأثر الكبير في عددٍ من المتغيرات التابعة. 
ويمكن عزو نتيجة السؤال الرابع -لتي تدل على الفاعلية الكبيرة لتدريس العلوم الثرعية في ضوء نهج النظم المتداخلة وفقاً للأنموذج المقترح في تنمية مهارات التفكير الاستدلالي

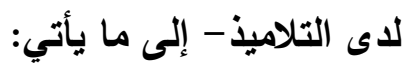

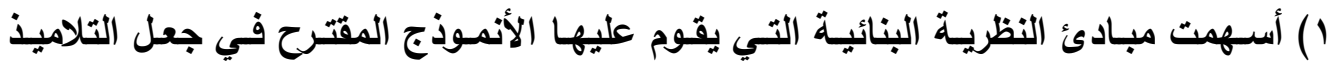
نثطين يبنون معارفهم بأنفسهرم؛ ومسن ثم مارسـوا مهارات التفكير الاستـلالي الثثلاث:

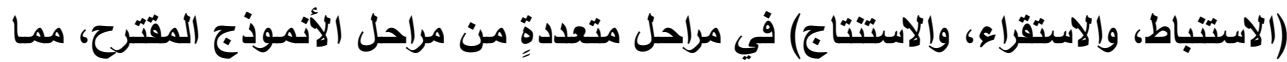
أدى إلى تنميتها لايهم. r) واجه الأنموذج المقترح التلاميذ أثناء التعلم بمواقف ومشكلاتٍ حقيقيةٍ من الواقع وذات

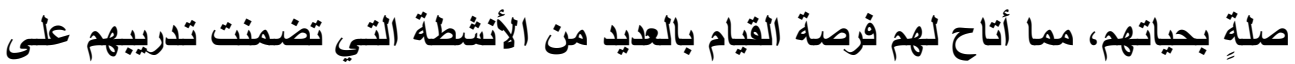
مهارات التفكير الاستدلالي. r) ساعد الأنموذج المقترح في تنمية مهارة الاستتباط لاى التلاميذ من خلال مراحل الأنموذج الأني الآتية: (إثارة انتباه التلاميذ للارس، واستكثـاف احتياجـات التلاميذ في الدرس، والبحث

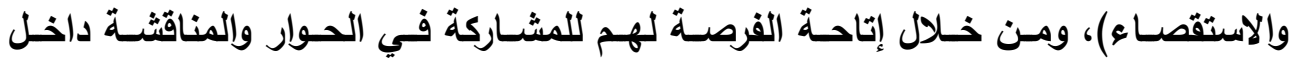
المجموعات التعاونيـة، ومحاولـة استنباط نتائج منطقيـةٍة حول الأفكار الكبرى (المفـاهيم

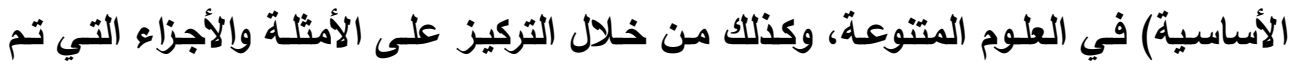

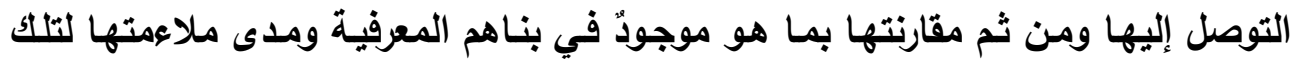
الأفكار الكبرى (المفاهيم الأساسية).

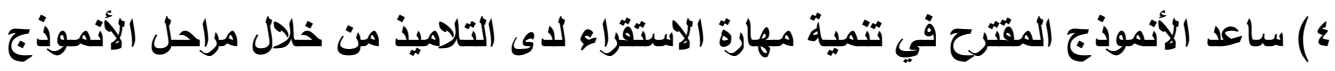
الآتية: (إثارة انتباه التلاميذ للدرس، واستكثـاف احتياجات التلاميذ في الدرس، والبحث والاستقصاء)، ومن خلال تتبعهم للأفكار الكبرى (المفاهيم الأساسية) من الأمثلة والأجزاء

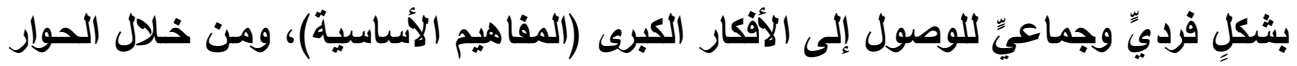

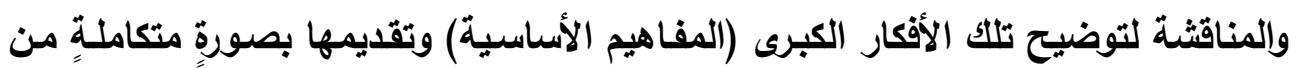
خلال العلوم المتنوعة، ومن ثم إعادة عرضها في خرائط مفاهيم.

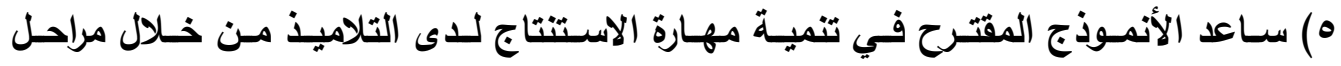

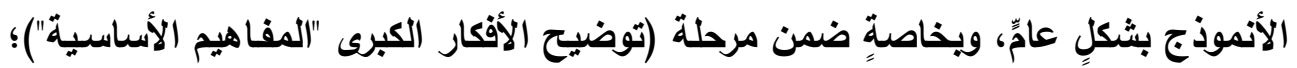

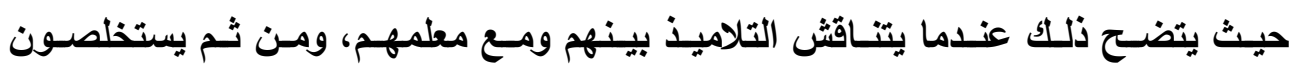


ويسـتتجون نتـائج جديـدةً بنـاءً على مـا توصـلوا إليـه حـول الأفكـار الكبـرى (المفـاهيم (الأساسية).

؟) استخدم الأنموذج المقترح طرائق للتدريس وإستراتيجياتٍ تنمي مهارات التفكير الاستدلالي، كـالطريقتين الاسـتنباطية والاسـتقرائية -اللتين تمـثلان مهـارتين مسن مهـارات التفكيـر

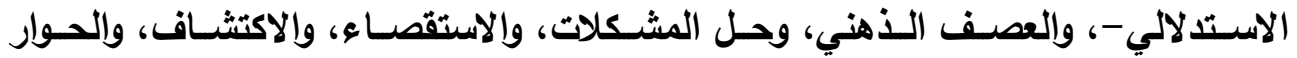
والمناقشة...

V قدَّم الأنمـوذج المقترح أنثطةً استقصـائيةً متنوعةةً أثثارت دافعيـة التلاميذ، وأتاحت لهم التفكير الاستدلالي من خلال القيام باستخدام المعلومـات المتعددة من مصادر تعليمٍا وتعلمِ

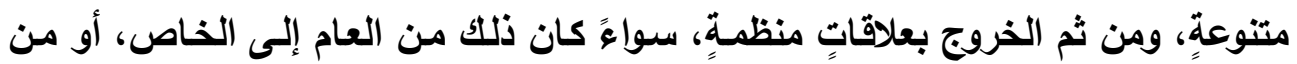
الخاص إلى العام، أو استنتاج حقائق معينةٍ.

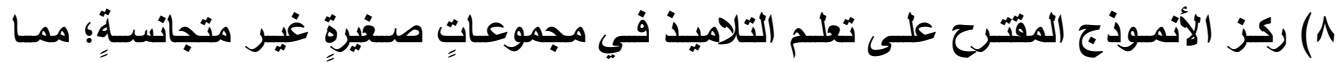

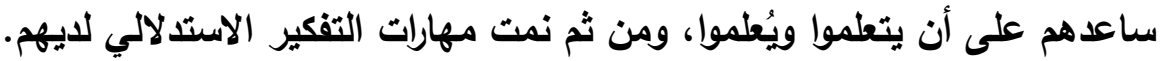

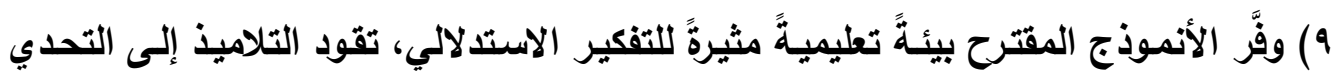
والبحث والاستقصاء وتبادل الأفكار . • 1) استخلم الأنموذج المقترح خرائط المفاهيم في مرحلة (توضيح الأفكار الكبرى "المفاهيم الأساسية")، وهذه الخرائط زودتهم بمهارة البحث عن أنمـاطٍ وعلاقِاتٍ بين تلك الأفكار الكبرى (المفاهيم الأساسية) في التخصصات المتنوعة؛ مما أدى إلى تتمية مهارات التفكير الاستدلالي لديهم. ويناءً على مـا سبق؛ تم رفض الفرضية الصفرية، وقبول الفرضية البليلة الذي تنصُّ على الآتي:

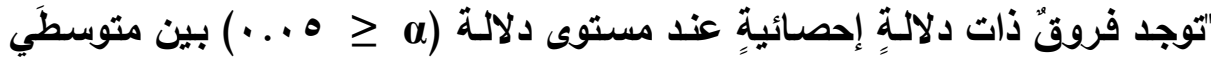
درجات تلاميذ المجموعتين التجريبية والضابطة في التطبيق البعدي لاختبار مهارات التفكير الاستدلالي، لصالح المجموعة التجريبية". 


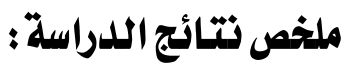

أسفرت نتائج الاراسة عن الآتي:

1) تحديد قائمةٍ بالمفاهيم الثرعية في وحدة "الزكاة" من مقرر الفقه، المراد إكسابها لتلاميذ

الصف السادس الابتّائي.

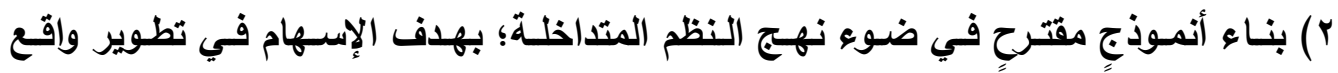

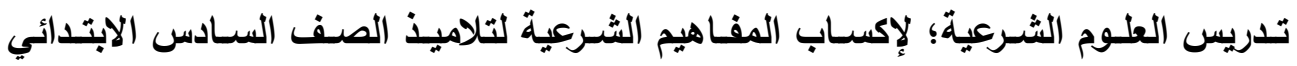
وتنمية مهارات التفكير الاستدلالي لديهم.

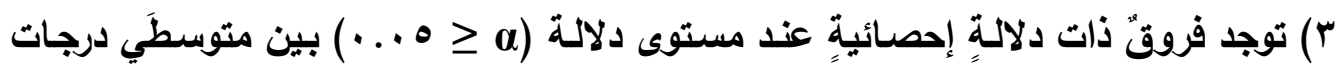
تلاميذ المجموعتين التجريبية والضابطة في التطبيق البعدي لاختبار المفاهيم الثرعية،

وفي كل مستويات الاختبار، ولصالح المجموعة التجريبية.

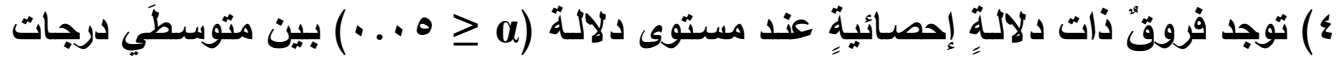

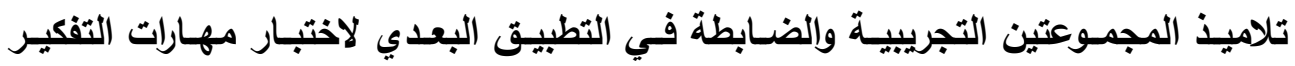

الاستدلالي، وفي كل مهارات الاختبار، ولصالح المجموعة التجريبية.

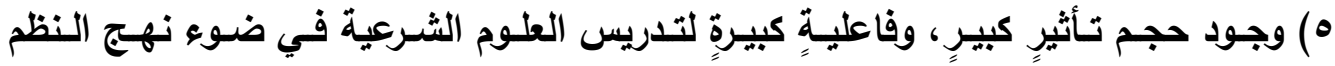
المتداخلـة وفقاً للأنموذج المقترح في إكساب المفاهيم الثرعية وتنمية مهارات التفكير

الاستدلالي لاى تلاميذ المجموعة التجريبية.

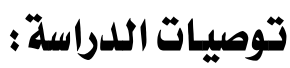

في ضوء ما أسفرت عنه نتائج الدراسة؛ يمكن تقليم التوصيات الآتية:

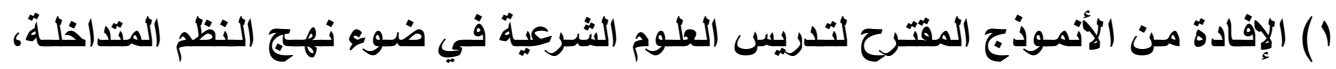

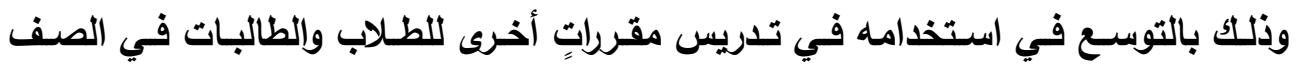
السادس الابتدائي، وفي الصفوف الأخرى بالمراحل المتنوعة.

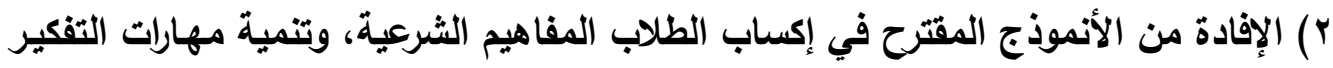

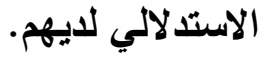

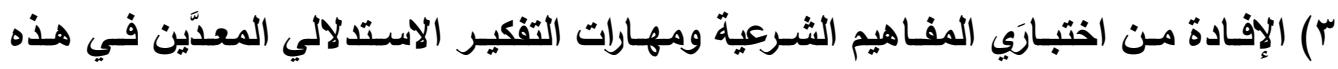

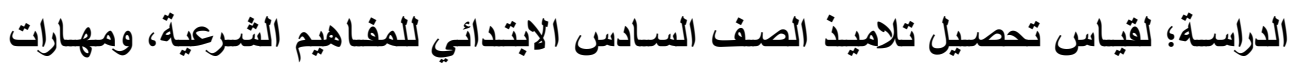

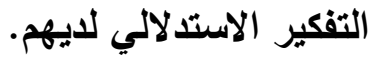




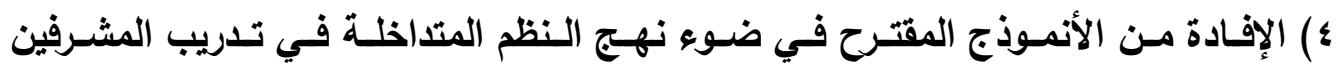
التربويين والمعلمين -في جميع التخصصـات- على التدريس باستخدام هذا الأنموذج؛ وذلك مـن خـلال إعداد البرامج التدريبيـة وعقد ورش العمل المناسبة لـلكت، والاسترشـاد بلاليل المعلم في هذه الدراسة؛ لما ثبت فيها من فاعلية هذا الأنموذج في إكساب المفاهيم الثرعية وتنمية مهارات التفكير الاستدلالي لاى التلاميذ.

\section{مقترحات اللدراسة :}

في ضوء ما أسفرت عنه نتائج الدراسة، ويناءً على التوصيات السـابقة؛ تم اقتراح إجراء

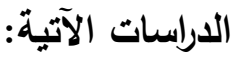
( ) تطوير تـدريس العلـوم الشـرعية في ضـوء نهـج النظم المتذاخلـة وفاعليتهـه في إكسـاب المفاهيم الشرعية وتنمية مهارات التفكير الاستدلالي لاى الطلاب/ الطالبات في صفوف المراحل التعليمية المتنوعة، وفي مناطق أخرى؛ للوقوف على إمكانية تعميم النتائج. r) تطوير تدريس العلوم الشرعية (أو مقراتٍ أخرى) في ضوء نهج النظم المتداخلة وفاعليته في تنمية متغيراتٍ تابعةٍ أخرى، مثل: المفاهيم الفقهية أو غيرها من المفاهيم، والتحصيل

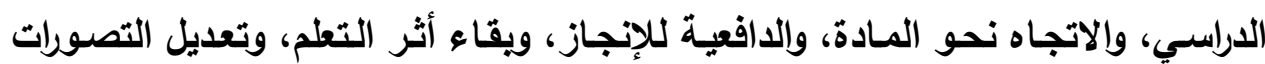
البديلة، ومهارات التفكير الناقد، ومهارات التفكير الإبداعي، ومهارات حل المشكلات...

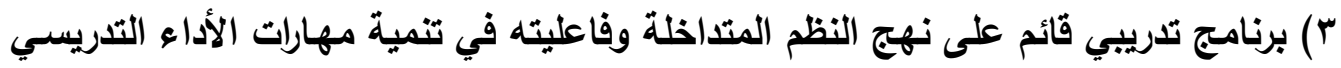
لاى المعلمين. ؛ ) فاعلية تدريس العلوم الثرعية (أو مقرراتٍ أخرى) باستخدام الأنموذج المقترح في هذه الاراسة.

ه) تطوير مقررات العلوم الشرعية (أو مقرراتٍ أخرى) في ضوء نهج النظم المتداخلة.

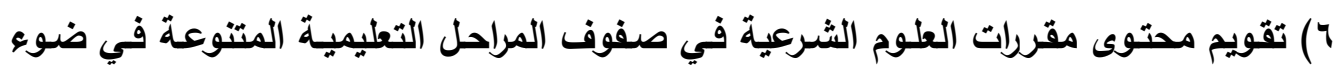
تضمنها لمهارات التفكير الاستدلالي. 


\section{المراجع}

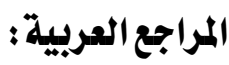

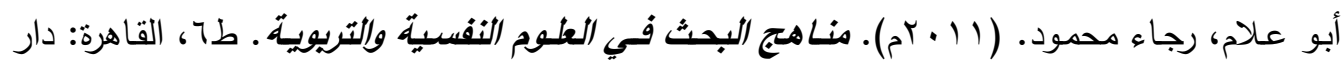

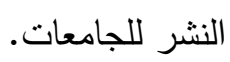

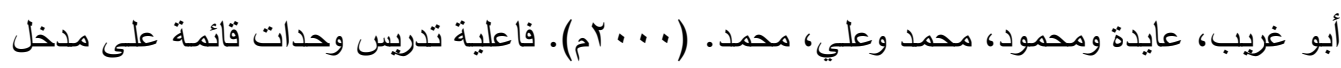

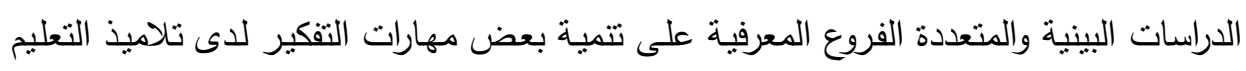

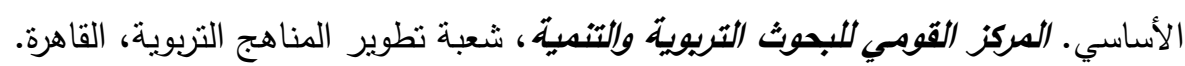

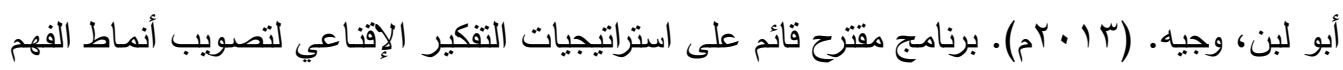

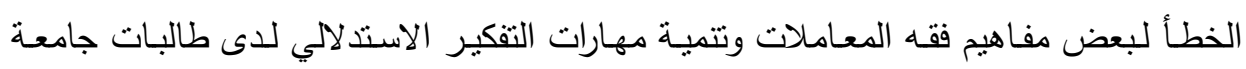

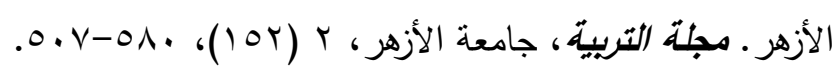

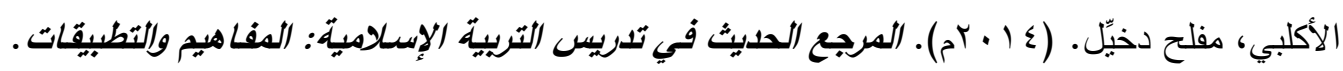

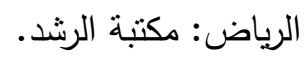

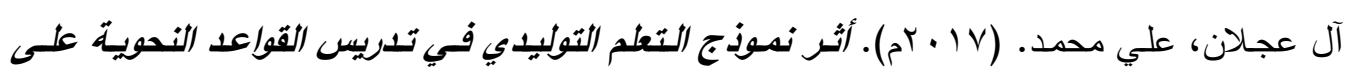

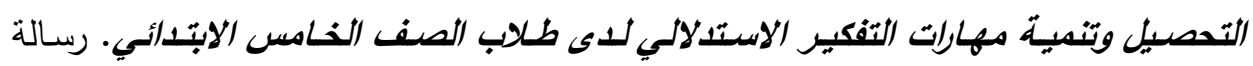
ماجستير غير منشورة، جامعة الملك خالد، أبها.

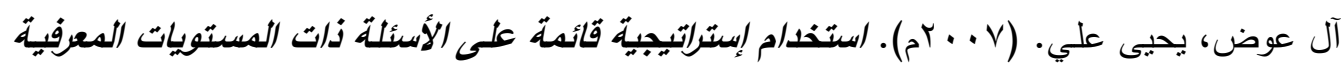

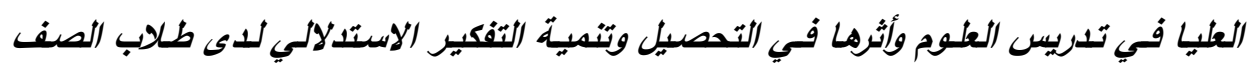
السادس الابتائي. رسالة ماجستير غير منشورة، جامعة الملكائك خالد، أبها.

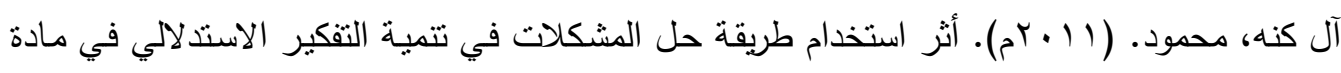

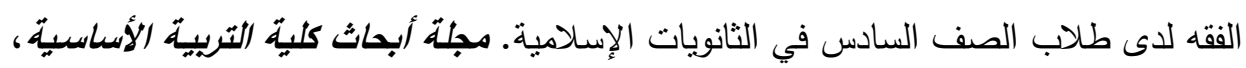

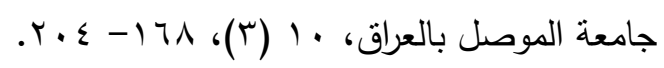

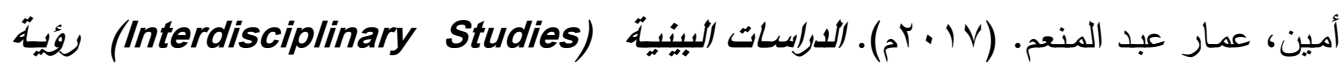

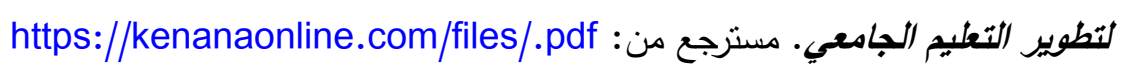

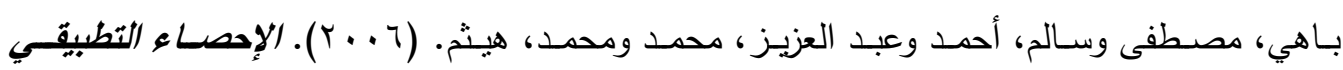
باستخدام الحزم الجاهزة . القاهرة: مكتبة الأنجلو المصرية. البخاري، محمد بن إسماعيل. (991 (م). صحيح البخاري. الرياض: بيتيث الأفكار الدولية. 


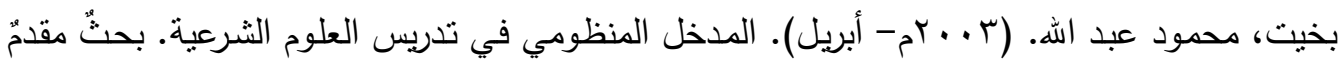
إلسى المؤتمر العريّي الثالث: المدخل المنظومي في التلديس والتعلم، مركز تطوير تدريس العلوم بجامعة عين شمس وجامعة جرش الأهلية، القاهرة، أبريل - r م . rم.

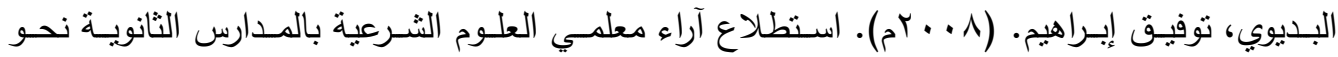
استخدام الحاسـب الآلكي في تدريس مـواد العلـوم الثـرعية. مجلـة العلـوم التربويستة والدراسـات

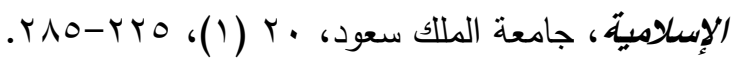

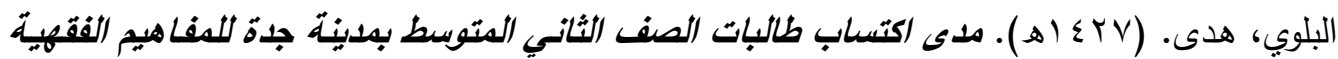
المقرة. رسالةة ماجستبر غير منشورة. كلية التربية للبنات، جدة.

بو هلال، محمد والقاسم، عبد العزيز وسخانة، محمد والنهدي، عز الدين والبكوش، لطفي والزين، مختار والصيخان، سليمان. (11 • (rم). مناهج العلوم الشرعية في التعليم السعودي: استقراء، تطبل،

$$
\text { تقويم. بيروت: الثبكة العربية للأبحاث والنشر • }
$$

بيومي، محمد سيد. (7 ( • r م). معوقات تفعيل الدراسـات البينية في العلوم الاجتماعية: دراسـة ميدانية.

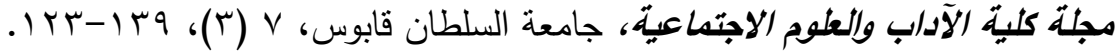

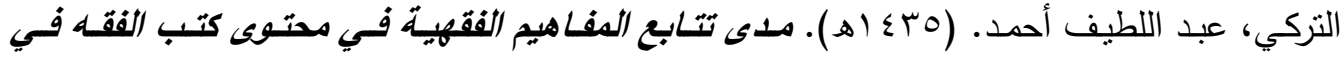
المرحلة المتوسطة بالمملكـة العربية السعولية. رسالة ماجستير غير منشورة، جامعة الإمام محمد بن سعود الإسلامية، الرباض. جاب الله، علي وداود، سليمان. (1 1 • r م). أثز إستراتيجية خرائط المفاهيم في اكتساب المفاهيم الثرعية والتحصيل الدراسي للطلاب الناطقين بغير العربية. مجلّة العلدوم التريويةة، جامعة الملك سعود،

$$
\text { . }
$$

جبر ، آلاء مأمون رشيد. (T 1 • rم). أثر توظيف نهج النظم المتد/خلة في منهاج الفنون والحرف على التفكير الإبـ/عي والدافعية لدى طلبة الصف السادس الأساسسي في محافظة سلفيت: حالـة دراسيةّ . رسالة ماجستير غير منشورة، جامعة النجاح الوطنية، نابلس، فلسطين.

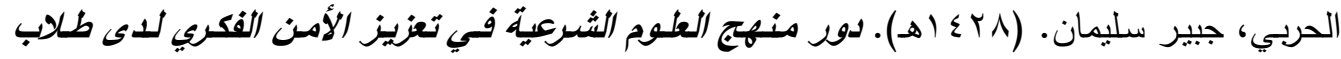
الصف الثالث الثانوي. رسالة ماجستير غير منشورة، جامعة أم القرى، مكة المكرمة. الحربي، جبير سليمان • (ד ا • rم). واقع استخدام التعليم المتمـازج في تدريس مقررات العلوم الثرعية

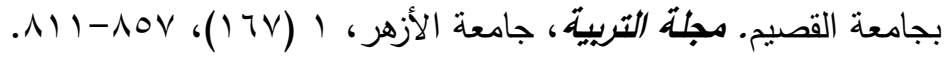
حسن، حسن فاروق. (0 ( ب م). أثز اختلاف مسنوى التفاعل في القصة الإلكترونية وموقعها في برامج الكمبيوتر التعليمية في تتمية المفاهيم الإسـالامية لدى تلاميذ الصف السادس الابتدائي. مجلـة 


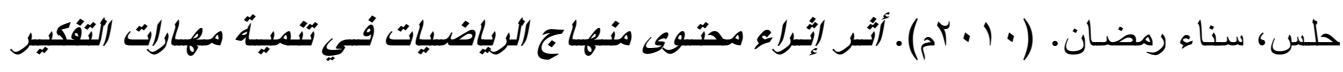
الاستدلكي للى طلاب الصف الحادي عشر العلمي. رسالة ماجسنير غير منشورة، جامعة غزة، فلسطين.

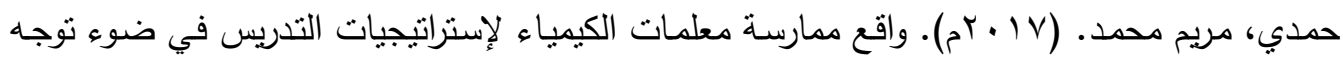

$$
\text { STEM }
$$

خضير، سعد محمد. (ع ا • rم). أثر أنموذج ميرل تتسون في اكتساب المفاهيم الإسـامية لدى تلاميذ

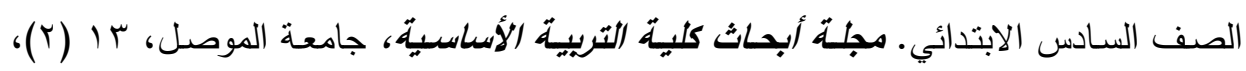
$.100-11$.

خليل، نوال عبد الفتاح. (r I • rم). أثر استخدام برنـامج كورت في تحصيل العلوم وبقاء أثر التعلم وتتميـة التفكير الاسـدلالي لدى تلاميذ الصـف السـادس الابتدائي. المجلـة المصسية للتربيـة

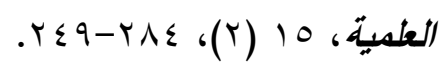

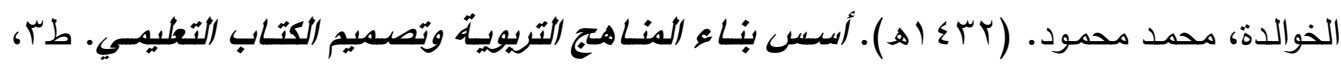
عمَّان: دار المسيرة.

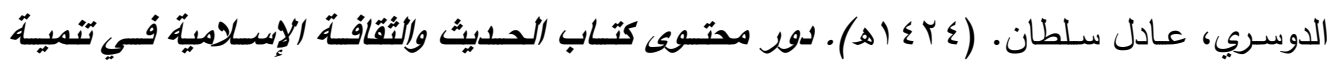
الاتجاهات الإيجابية لـى طلاب الصف الثالث الثانوي في المنطقة الشسقية. رسالة دكتوراه غير منشورة، جامعة أم القرى، مكة المكرمة. رزوقي، رعد مهدي وعبد الكريم، سـهى إبراهيم. (10 • بم). التفكير وأنعاطسه: التفكبر الاستدلاهيالتفكير الإباعي- التفكير المنظومي- التفكير البصري. جن، عمَّان: دار المسيرة. زهران، حامد عبد السلام. (0 . . rم). علم نفس النمو- الطفولة والمراهقة. طج، القاهرة: عالم الكتب.

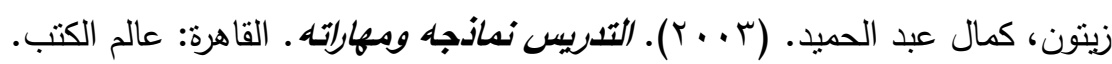
سعادة، جودت أحمد. (7 ا • rم). مناهج الدراسات الاجتماعيةً. . عمَّان: دار الفكر ناشرون وموزعون. السعدي، إسحق بن عبد الله. (T I ـrم). دراسات في تمبز الأمة الإسلامية وموقف المستشرقين منسه. قطر : وزارة الأوقاف والثؤون الإسلامية.

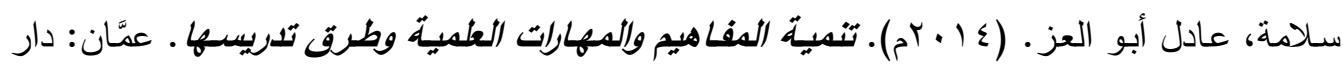
الفكر ناشرون وموزعون. السليم، غالية حمد. (r ( • rم). معوقات استخدام إستراتيجية التعليم المتمايز في تدريس مقررات العلوم الثـرعية في المرحلة الابتدائيسة مـن وجهة نظر المعلمات في مدينـة الريـاض. مجلـة التربيـة،

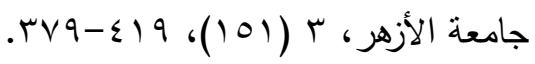


سليمان، أمين علي وأبو علام، رجاء محمود. (9 . . rم). القياس والثقويم في العلوم الإنسانية: أسسـ وأدواتها وتطبيقاتهـ. القاهرة: دار الكتاب الحديث.

السـلي، عبد الله محمد. (r . . r م). تحصيل طلاب الصف الثالث الثانوي (شسعي) مفاهيم مصطلح الحليث. رسالة ماجستير غير منشورة، جامعة الملك سعود، الرياض.

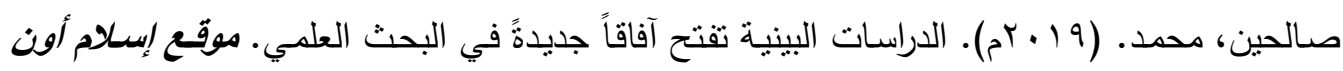
https://islamonline.net/29363 لابين. مسترجع من:

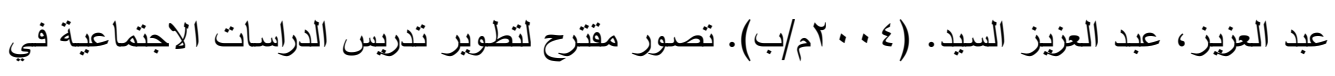

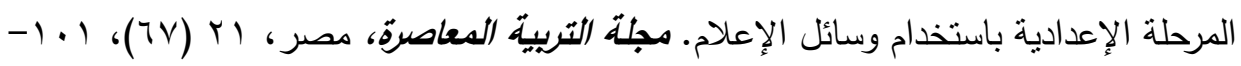

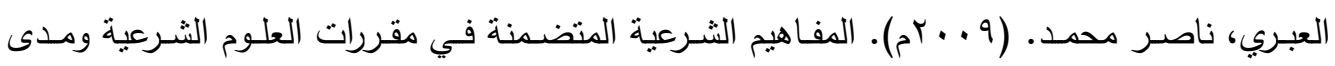

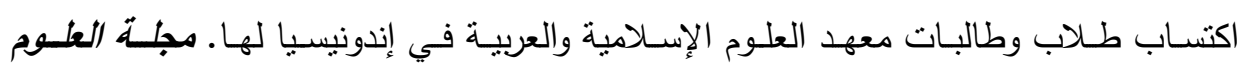

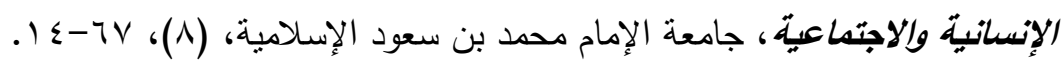

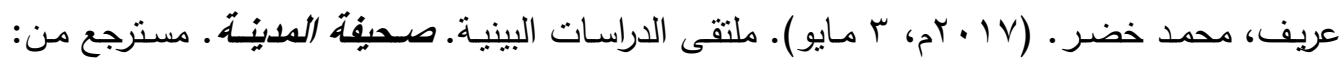
https://www.al-madina.com/article/521967 عصر ، حسني عبد الباري. (0 . . rم). التفكير مهاراتـه، وإستراتيبيات تلـبسـه. الإسكندرية: مركز الإسكندرية للكتاب.

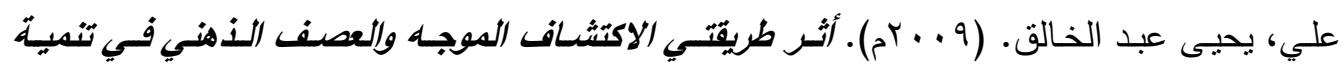
مهارات التفكبر الناقد والتحصيل في مادة الفقه لدى طلاب المرحلتة الثانويـة في مدينة تبوك. رسالة دكتوراه غير منشورة، جامعة أم القرى، مكة المكرمة. العنزي، فاتن بنت حوران. ( (ب اء اهـ). أثر توظيف المدخل المنظومسي في إكساب المفاهيم الفقهية للدى طالبات المستوى الأول الثانوي (النظام الفصلي) · رسالة ماجستير غير منشورة، جامعة الإمام محمد بن سعود الإسلامية، الرياض.

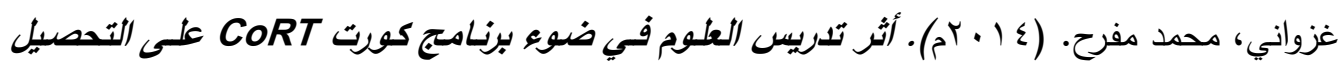
وتنمية مهارات التفكير الاستدلالسي لدى طلاب الصف السادس الابتدائسي. رسالة ماجستير غير منشورة، جامعة الملك خالد، أبها. الغنـام، محرز عبده. (ج . . rم). فعالية تدريس العلوم بإسـتراتيجية التعلم المتمركز حول المشكلة في التحصبل وتتمية كل من التفكير الاستدلالي والناقد لدى تلاميذ الصف الأول الإعدادي. مجلة

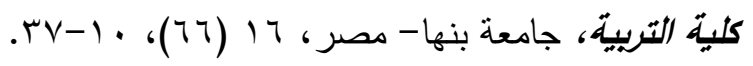


فتح الله، مندور عبد السلام. (19 (م). مدخل النظم المتداخلة في بناء وحدات المنهج الدراسي. مجلة

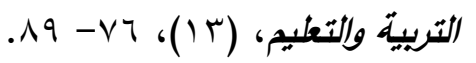

الفضيلي، محمد علي. (0 1 • rم). فعالية تلديس العلوم باستخدام أنمـذج التعلم التوليذي في تعديل التصولات البلياتة وتنمية مهالات التفكير الاستدلالسي لدى طلاب الصف السادس الابتدائسي. رسالة ماجستير غير منشورة، جامعة الملك خالا، أبها. قاموس ومعجم المعاني. ( • ( • rم). قاموس ومعجم المعانسي: متعدد اللغات والمجالات .

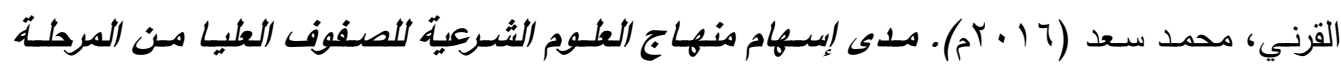
الابتدائية فـي إكساب التحلاميذ مفـاهيم الأمسن الفكسري من وجهية نظر المعلمسين والمشسفين التريويين. رسالة ماجستير غير منشورة، جامعة الإمام محمد بن سعود الإسلامية، الرياض.

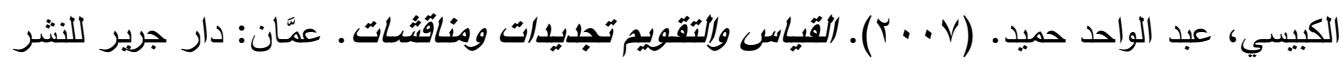
والتوزيع.

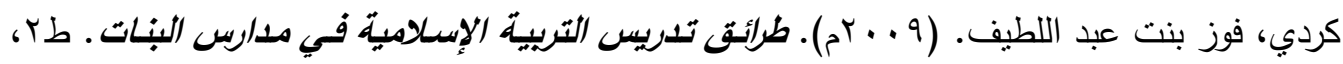
جدة: دار الأندلس الخضراء.

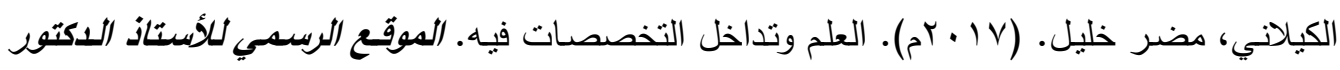

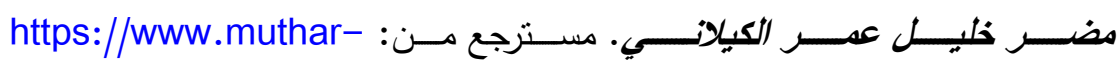
alomar.com $/ \mathrm{p}=886$ المالكي، عبد الرحمن عبد الله. (T . . rم). المفاهيم المكية في كتب التربية الإسـلامية للصفوف العليا

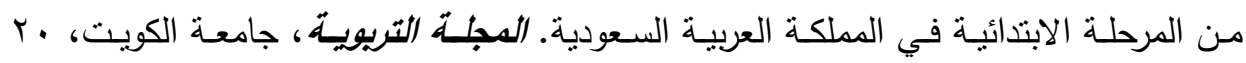
$.10 V-r .96(\vee 9)$ محمود، عبد الرزاق وسيد، عبد الوهاب وعمران، عزت. (7 ( • rم). فاعلية إستراتيجية النمذجة المدعومة بالويب كويست في عـلاج الفهم الخطأ لبعض المفاهيم الدينية الإسـلامية لدى تلاميذ المرحلة

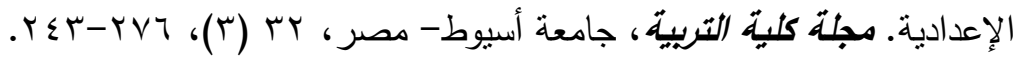

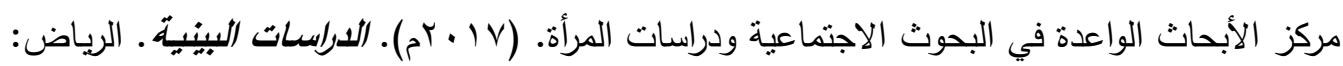
جامعة الأميرة نورة بنت عبد الرحمن. المطرودي، خالد إبراهيم. (9 جـ اهـ). مدى اكتساب تلاميذ الصف السادس الابتدائي بمدينة الرياض

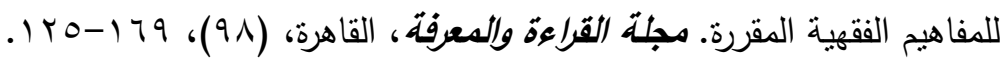

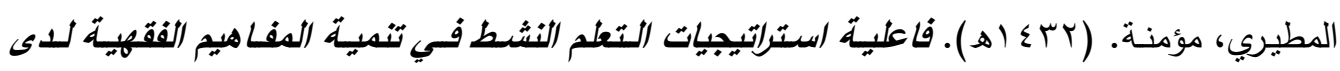
طالبات الصف الأول الثانوي ببلينة الرياض. رسالة دكتوراه غير منشورة، جامعة الإمام محمد بن سعود الإسلامية، الرياض. 
المقاطي، صالح إبراهيم. (1 ( • rم). معوقات تطبيق إستراتيجيات التدريس الحديثة في تدريس مقررات

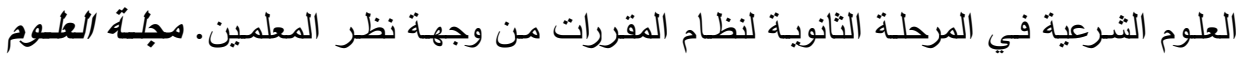

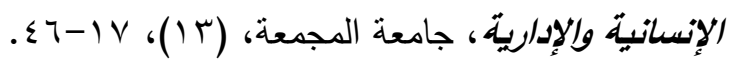

مكتب التربية العربي لدول الخليج. (مبـ (هـ). واقع استخدام إستراتيجيات تلدريس التريية الإسلامية من قبل المعلمين- دراسة مسحية. الرياض: مكتب التربية العربي لدول الخليج.

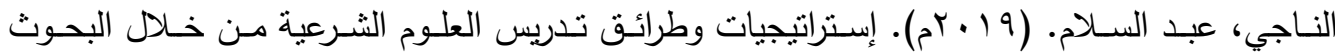

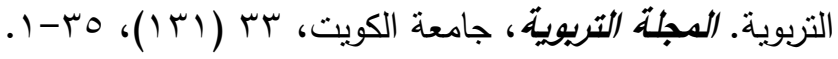

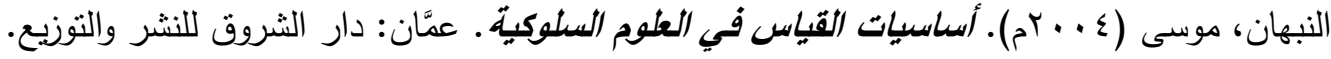

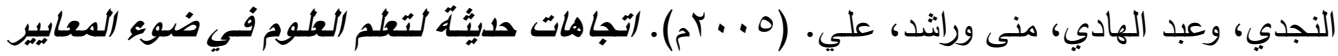

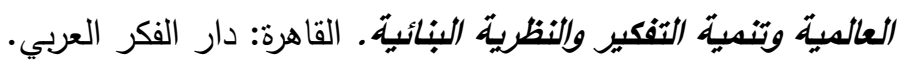

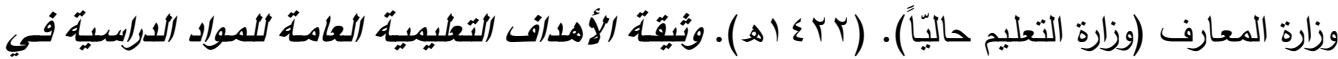

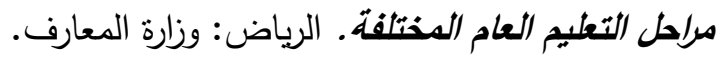

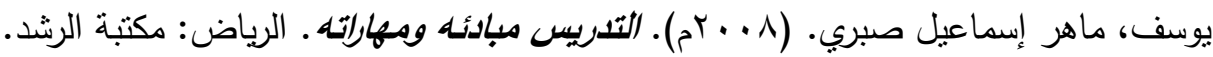
المراجع الأجنبية : المبية

Boehm, R. (2003). The Best of Both Worlds: Blending History and Geography in the K-12 Curriculum. Gilbert M. Grosvenor Center for Geographic Education.

Bristow A. (2012) An Analysis of the Impact of Implementing Interdisciplinary Pods on Student Achievement in Georgia Middle Schools. Dissertation of Philosophy, The University of Southern Mississippi, USA.

Carroll, J. (2000). Words, Meanings and Concepts. Harvard Educational Review, 34 (2), 179-202.

Demirel M. \& Coskun, Y. (2010) Case Study on Interdisciplinary Teaching Approach Supported by Project Based Learning. Educational Research Association, The International Journal of Research in Teacher Education, 2 (3), 28-53.

Deneme, S. \& Ada, S. (2012). On applying the interdisciplinary approach in primary schools. Procedia- Social and Behavioral Sciences. (46), 885 -889 .

Duman B. \& Aybek, B. (2003). Comparison of Process-based and Interdisciplinary Teaching Approaches. Mugla University Journal of 
أنموذج مقترح لنطوير تدريس العلوم الشرعية في ضوء نهج النظم المتداخلة .

Institute of Social Sciences, (11), 1-12. Retrieved from:

http://www.mu.edu.tr/sbe/sbedergi/dosya/11_1.pdf

Haynes, C. (2002). Innovations in Interdisciplinary Teaching. West port, CT, American Council on Education ORYX Press

Ivanitskaya, L., Clark, D., Montgomery, G. \& Primeau, R. (2002).

Interdisciplinary Learning: Process and Outcomes. Innovative Higher

Education, 27 (2),95-111.

Mazzara, E. (2014). Using the Interdisciplinary Approach to Education to Meet the Literacy Standards in the Common Core: and Ensuring Graduates are College and Career Ready. Education and Human Development Master's Theses, University of New York College at Brockport, 352.

Novak, J. \& Gowin, D. ( $\uparrow . . \cdot)$. Learning How to Learn. London: Cambridge University Press.

Park, J. \& Mills, K. (2014). Enhancing Interdisciplinary Learning with a Learning Management System. MERLOT Journal of Online Learning and Teaching. 10 (2), 299-313.

Sagdic, M. \& Demirkaya, H. (2014) Evaluation of Interdisciplinary Teaching Approach in Geography Education. Electronic Journal of Social Sciences, 13 (49), 386-410.

You, H. (2017) Why Teach Science with an Interdisciplinary Approach: History, Trends, and Conceptual Frameworks. Journal of Education and Learning, 6 (4), 66-77. 